\title{
Hydrogeology and Simulation of Ground-Water Flow at Arnold Air Force Base, Coffee and Franklin Counties, Tennessee
}

By CONNOR J. HAUGH and ELIZABETH N. MAHONEY

U.S. Geological Survey

Water-Resources Investigations Report 93-4207

Prepared in cooperation with the

United States Air Force,

Arnold Air Force Base 


\title{
U.S. DEPARTMENT OF THE INTERIOR BRUCE BABBITT, Secretary
}

\author{
U.S. GEOLOGICAL SURVEY \\ Robert M. Hirsch, Acting Director
}

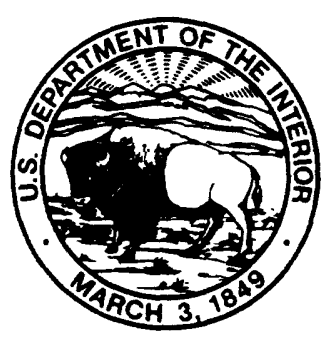

Any use of trade, product, or firm name in this report is for identification purposes only and does not constitute endorsement by the U.S.

Geological Survey.

For additional information write to:

District Chief

U.S. Geological Survey 810 Broadway, Suite 500

Nashville, Tennessee 37203
Copies of this report may be purchased from:

U.S. Geological Survey

Earth Science Information Center

Open-File Reports Section

Box 25286, MS 517

Denver Federal Center

Denver, Colorado 80225 


\section{CONTENTS}

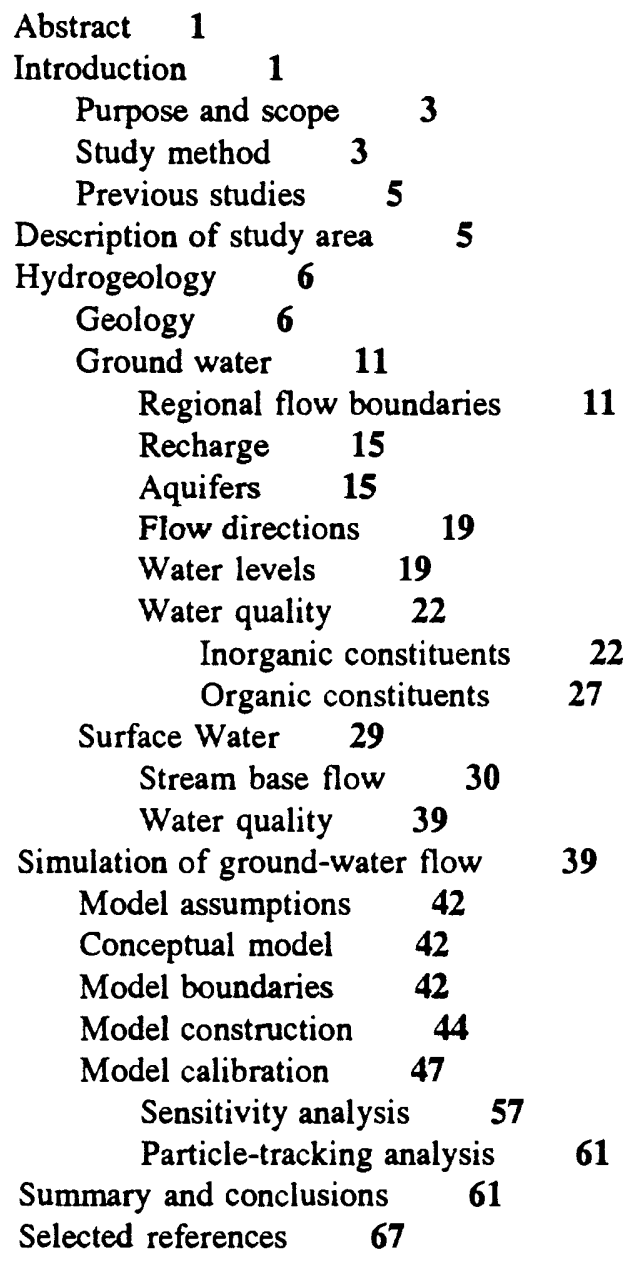

\section{FIGURES}

1-3. Maps showing:

1. Location of the study area in Coffee and Franklin Counties 2

2. Location of wells installed by the U.S. Geological Survey at the Arnold Air Force Base area 4

3. Geology of the Arnold Air Force Base area 7

4. Generalized geologic section $A-A^{\prime} \quad 8$

5. Generalized geologic section B-B' 9

6. Relation of stratigraphy, lithology, and hydrogeologic units in the Arnold Air Force Base 10

7. Map showing fracture traces mapped from aerial photographs of Amold Air Force Base 12

8. Rose diagram showing frequency and orientation of fracture traces at Amold Air Force Base

9. Map showing regional flow boundaries and location of hydrogeologic sections at the Arnold Air Force Base area 
10. Generalized hydrogeologic section $A-A^{\prime}$ along northern flow boundary at Wolf Creek 16

11. Generalized hydrogeologic section B-B' ${ }^{\prime}$ along eastern flow boundary at Bradley Creek 17

12. Generalized hydrogeologic section $\mathrm{C}^{-\mathrm{C}^{\prime}}$ along southwestern flow boundary at Rock Creek 18

13. Map showing generalized directions of regional ground-water flow in the study area, fall $1989 \quad 20$

14. Diagram showing hypothesis of secondary permeability in the Manchester aquifer and the effects of dewatering at the J4 test cell on water levels in the shallow, Manchester, and Fort Payne aquifers at Arnold Air Force Base 21

15-22. Hydrographs showing water levels in:

15. Well AEDC 213 from May 1991 through December $1992 \quad 23$

16. Well AEDC 215 from May 1991 through December $1992 \quad 23$

17. Well AEDC 219 from May 1991 through December $1992 \quad 24$

18. Wells AEDC 190 and 191 from May 1991 through December 1992

19. Wells AEDC 177 and 178 from May 1991 through December 1992

20. Wells AEDC 185 and 186 from May 1991 through December 1992

21. Wells AEDC 188 and 189 from May 1991 through December 1992

22. Wells AEDC 210 and 211 from May 1991 through December 1992

24

25

25

26

26

23-26. Trilinear diagrams showing chemical composition of water from:

23. Wells completed in the shallow aquifer at Arnold Air Force Base 27

24. Wells completed in the Manchester aquifer at Arnold Air Force Base 28

25. Wells completed in the Fort Payne aquifer at Arnold Air Force Base 29

26. Wells completed in the upper Central Basin aquifer at Arnold Air Force Base

27-30. Boxplots showing ranges of:

27. Dissolved solids concentration in ground water at Arnold Air Force Base

28. Sulfate concentration in ground water at Arnold Air Force Base 32

29. Chloride concentration in ground water at Arnold Air Force Base 33

30. Lithium concentration in ground water at Arnold Air Force Base 34

31. Map showing location of surface-water measuring stations in the Arnold Air Force Base area

32. Trilinear diagram showing chemical composition of water from surface-water stations at Arnold Air Force Base

41

33. The relation between geologic units of the natural system, hydrologic units of the conceptual model, and equivalent layers in the ground-water-flow model

34-40. Maps showing:

34. Grid cell types for the digital flow model 45

35. Active area of model grid used for the Arnold Air Force Base study area 46

36. Finite-difference grid showing range of thicknesses of layer 1 of ground-water-flow model of Arnold Air Force Base study area 48

37. Finite-difference grid showing range of thicknesses of layer 2 of ground-water-flow model of Arnold Air Force Base study area 49

38. Finite-difference grid showing range of thicknesses of layer 3 of ground-water-flow model of Arnold Air Force Base study area 50

39. Distribution of simulated rates of ground-water-flow model of Amold Air Force Base study area

40. Model-simulated water levels in layers 1, 2, and 3 for ground-water-flow model of Arnold Air Force Base study area

54

41. Diagram showing distribution of water-budget components among the layers of the digital flow model for the Arnold Air Force Base study area

42-44. Graphs showing sensitivity of ground-water-flow model of Arnold Air Force Base study area to adjustments in:

42. Hydraulic conductivity in layer 1 , layer 2 , and layer 3

iv Hydrogeology and Simulation of Ground-Water Flow at

Arnold Air Force Base. Coffee and Franklin Counties, Tennessee 
43. Vertical conductance between layers 1 and 2, and layers 2 and 3; and adjustments in river and drain conductance

44. Recharge, column-to-row anisotropy, and row-to-column anisotropy

60

45-48. Maps showing:

45. Location of sites used for particle-tracking analysis at Arnold Air Force Base 63

46. Forward particle tracking from Coffee County landfill (site 3) at Arnold Air Force Base

47. Forward particle tracking from Camp Forrest water-treatment plant (site 6) at Arnold Air Force Base

65

48. Forward particle tracking from leaching pit No. 1 (site 8) at Arnold Air Force Base

66

\section{TABLES}

1. Range and median values of selected inorganic constituents and physical properties in water from wells sampled at Arnold Air Force Base 35

2. Summary of water-quality and hydrogeologic characteristics for the aquifers at Amold Air Force Base 36

3. Summary by aquifer of concentrations of benzene, toluene, ethylbenzene, and xylene compounds in water from wells sampled at Arnold Air Force Base 36

4. Stream discharge measurements made on November 2, 1990 at stations in the Arnold Air Force Base area 38

5. Inorganic constituents and physical properties of surface-water samples from the Arnold Air Force Base area 40

6. Comparison of simulated to estimated average-annual water levels for ground-water-flow model of Arnold Air Force Base study area 53

7. Comparison of model-simulated streamflow to estimated average-annual stream base flow for ground-water-flow model of Arnold Air Force Base study area 53

8. Ranges of variation of hydraulic characteristics for sensitivity analysis of ground-water-flow model of Arnold Air ForceBase study area 62 


\section{CONVERSION FACTORS, VERTICAL DATUM, ABBREVIATIONS, AND ACRONYMS}

\begin{tabular}{|c|c|c|}
\hline Multiply & By & To obtain \\
\hline inch (in.) & 25.4 & millimeter \\
\hline inch per year (in/yr) & 25.4 & millimeter per year \\
\hline foot (ft) & 0.3048 & meter \\
\hline square foot $\left(\mathrm{t}^{2}\right)$ & 0.0929 & square meter \\
\hline mile (mi) & 1.609 & kilometer \\
\hline acre & 4,047 & square meter \\
\hline acre & 0.4047 & hectare \\
\hline square mile $\left(\mathrm{mi}^{2}\right)$ & 259.0 & hectare \\
\hline square mile $\left(\mathrm{mi}^{2}\right)$ & 2.590 & square kilometer \\
\hline cubic foot per second $\left(\mathrm{ft}^{3} / \mathrm{s}\right)$ & 0.02832 & cubic meter per second \\
\hline ubic foot per second per square mile $\left[\left(\mathrm{ft}^{3} / \mathrm{s}\right) / \mathrm{mi}^{2}\right]$ & 0.01093 & cubic meter per second per square mile \\
\hline gallon per minute ( $\mathrm{gal} / \mathrm{min}$ ) & 0.06308 & liter per second \\
\hline gallon per minute per foot $[(\mathrm{gal} / \mathrm{min}) / \mathrm{tt}]$ & 0.2070 & liter per second per meter \\
\hline foot per day ( $\mathrm{t} / \mathrm{d})$ & 0.3048 & meter per day \\
\hline foot squared per day $\left(\mathrm{ft}^{2} / \mathrm{d}\right)^{*}$ & 0.09290 & meter squared per day \\
\hline
\end{tabular}

Temperature in degrees Fahrenheit $\left({ }^{\circ} \mathrm{F}\right)$ can be converted to degrees Celsius $\left({ }^{\circ} \mathrm{C}\right)$ as follows:

$$
{ }^{\circ} \mathrm{C}=5 / 9 \times\left({ }^{\circ} \mathrm{F}-32\right)
$$

*Transmissivity: In this report transmissivity is expressed as foot squared per day $\left(\mathrm{ft}^{2} / \mathrm{d}\right)$ - The standard unit for transmissivity $(T)$ is cubic foot per day per square foot times foot of aquifer thickness " $\left[\left(\mathrm{f}^{3} / \mathrm{d}\right) / \mathrm{ft}^{2}\right] \mathrm{ft}^{\text {" }}$ or cubic meter per day per square meter times meter of aquifer thickness $"\left[\left(\mathrm{~m}^{3} / \mathrm{d}\right) / \mathrm{m}^{2}\right] \mathrm{m} n$. These mathematical expressions reduce to foot squared per day " $\left(\mathrm{ft}^{2} / \mathrm{d}\right)^{n}$ or meter squared per day " $\left(\mathrm{m}^{2} / \mathrm{d}\right)^{n}$.

Sea Level: In this report "sea level" refers to the National Geodetic Vertical Datum of 1929 (NVGD of 1929) - a geodetic datum derived from a general adjustment of the first-order level nets of the United States and Canada, formerly called Sea Level Datum of 1929.

\section{ABBREVIATIONS AND ACRONYMS}

AAFB
AEDC
BTEX
IRP
MODFLOW
MODPATH
RMSE
USGS
ZONEBUDGET

Amold Air Force Base

Arnold Engineering Development Center

Benzene, toluene, ethylbenzene, and xylene Installation Restoration Program

U.S. Geological Survey modular three-dimensional finite-difference ground-water-flow model A computer program to compute and display pathlines using results from the U.S. Geological Survey modular three-dimensional finite-difference ground-water-flow model

Root mean square error

United States Geological Survey

A computer program for calculating subregional water budgets using results from the U.S. Geological Survey modular three-dimensional finite-difference ground-water-flow model 


\title{
Hydrogeology and Simulation of Ground-Water Flow at Arnold Air Force Base, Coffee and Franklin Counties, Tennessee
}

\author{
By Connor J. Haugh and Elizabeth N. Mahoney
}

\section{Abstract}

The U.S. Air Force at Arnold Air Force Base, in Coffee and Franklin Counties, Tennessee, is investigating ground-water contamination in selected areas of the base as the result of activities associated with (1) aerospace system testing at Arnold Engineering Development Center, (2) Air Force Base operations, (3) Coffee County landfill activities, and (4) historical military staging at Camp Forrest. This report documents the results of a comprehensive investigation of the regional hydrogeology of the Arnold Air Force Base area.

The area is underlain by two aquifer systems: the Highland Rim aquifer system and the upper Central Basin aquifer system. Three aquifers comprise the Highland Rim aquifer system in the study area: the shallow aquifer, the Manchester aquifer, and the Fort Payne aquifer. Of these, the Manchester aquifer is the primary source of water for domestic use. This aquifer consists of waterbearing chert rubble and solution openings and fractures in the upper part of the bedrock. Drilling and water-quality data indicate that the Chattanooga Shale is an effective confining unit, isolating the Highland Rim aquifer system from the deeper, upper Central Basin aquifer system.

A regional ground-water divide, approximately coinciding with the Duck River-Elk River drainage divide, underlies Arnold Air Force Base and runs from southwest to northeast. The general direction of most ground- water flow is to the northwest or to the southeast from the divide towards tributary streams that drain the area. Recharge to the groundwater system is primarily from precipitation, and estimates of average annual recharge rates range from 4 to 11 inches per year.

Digital computer modeling was used to simulate and provide a better understanding of the ground-water-flow system. The model indicates that most of the ground-water flow occurs in the shallow and Manchester aquifers. The model was calibrated as a steady-state simulation of average annual conditions. The overall root mean square error was 14 feet. The model was most sensitive to increases in hydraulic conductivity of the shallow aquifer and the Manchester aquifer, changes in recharge rates, and the addition of anisotropy.

Particle-tracking analysis from selected sites of ground-water contamination indicate that the contaminants have potential to be transported beyond the boundary of Arnold Air Force Base.

\section{INTRODUCTION}

Arnold Air Force Base (AAFB) occupies about 40,000 acres in Coffee and Franklin Counties, Tennessee (fig. 1). Arnold Engineering Development Center (AEDC), encompassing about 4,000 acres in the center of the Air Force base, is an aerospace system testing facility for the Air Force Material Command. As part of the U.S. Air Force Installation Restoration Program (IRP), 


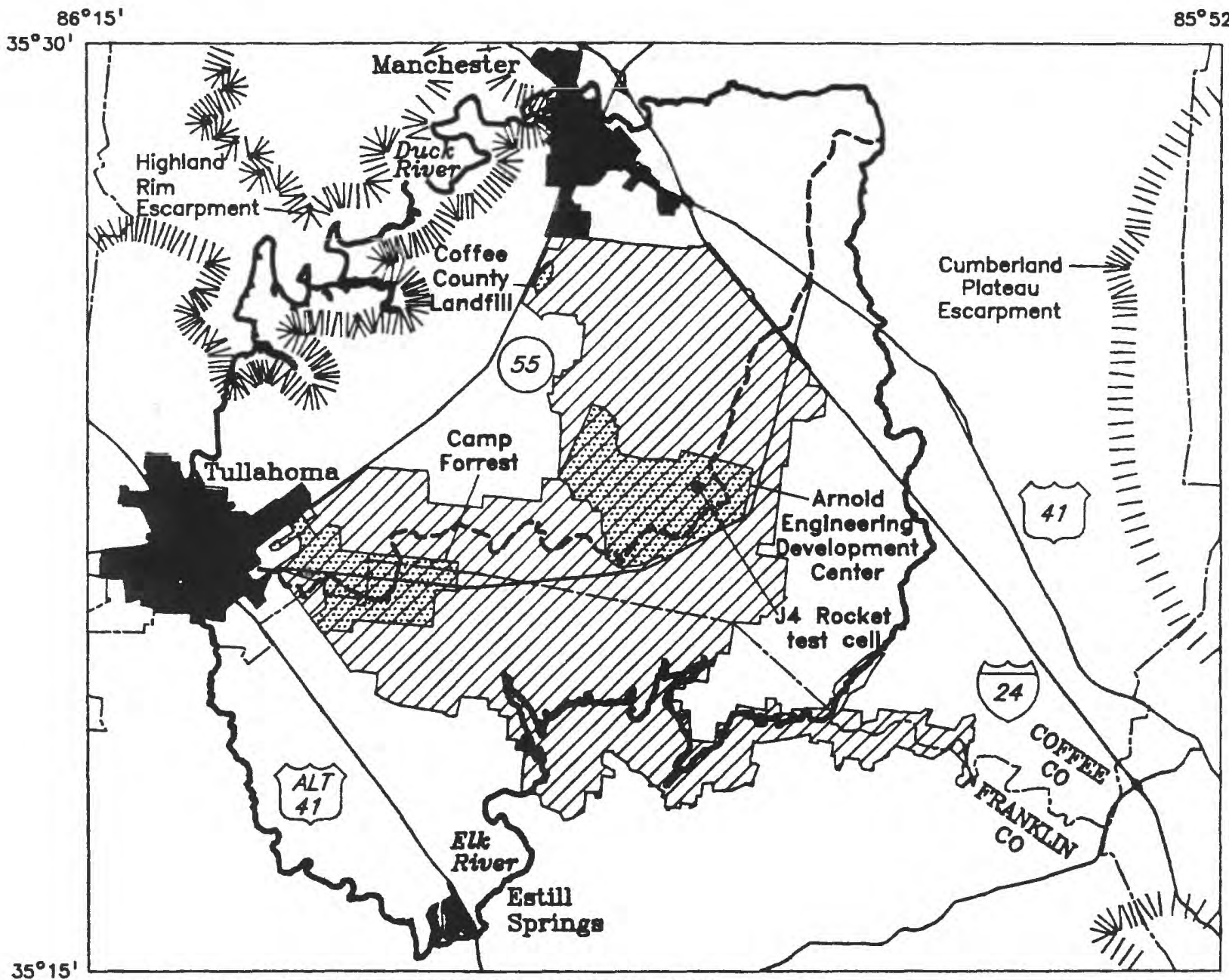

Bese from U.S. Geological Survey digital data, 1:1000,000, 1983 Universal Tranaverse Mercator projection, zone 16
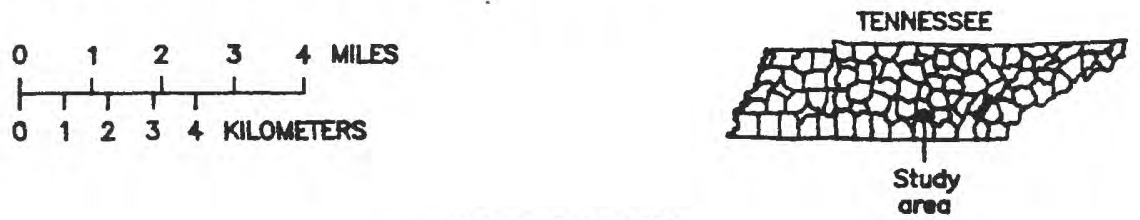

\section{EXPLANATION}

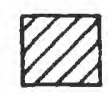

ARNOLD AIR FORCE BASE

INCORPORATED TOWNS

HYDROLOGIC BOUNDARY--

Delineation of recional

ground-water-flow

gystem underlying

Arnold Air Force Base

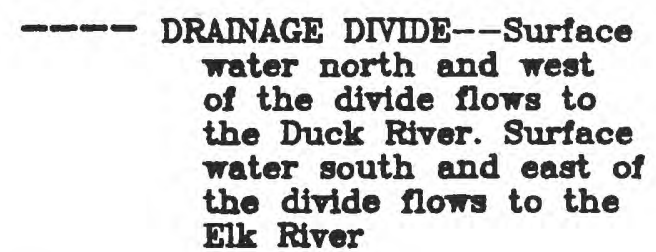

IIIIIII ESCARPMGTNT

Figure 1. Location of the study area in Coffee and Franklin Counties.

2 Mydrogeology and Simulation of Ground-Water Flow at

Arnold Air Force Base, Coffee and Franklin Counties, Tennessee 
many site-specific ground-water investigations have been conducted at sites of potential ground-water contamination. These investigations have shown that ground-water contamination has occurred as the result of activities associated with (1) aerospace system testing at AEDC, (2) routine Air Force base operations, (3) the Coffee County landfill, and (4) historical military staging at Camp Forrest.

Dewatering at one of the AEDC test facilities, the J4 rocket test cell, imposes a stress on the ground-water system. The J4 test cell is 100 feet in diameter and 300 feet deep. A network of six peripheral wells drain into a sump near the bottom of the test cell, keeping the surrounding aquifers dewatered locally. This is the only major hydrologic stress on the ground-water system at Arnold Air Force base.

Because the many previous studies have been site specific, the overall hydrogeology of the base area was not well defined. To provide such an overview, from 1989 to 1992, the U.S. Geological Survey (USGS), in cooperation with the U.S. Air Force and Arnold Air Force Base, conducted a comprehensive investigation of the hydrogeology of the AAFB area. The purpose of the investigation was to define the hydrology of the AAFB area in sufficient detail to aid in addressing ground-water contamination problems and managing the ground-water resources.

\section{Purpose and Scope}

This report describes the results of the hydrogeologic investigation of Arnold Air Force Base. The report includes a definition of lithology and hydraulic properties of the aquifers, description of ground-water flow, description of ground-water and surface-water quality, quantification of inflows and outflows of the ground-water system, conceptualization of the ground-water-flow system, description of the development and calibration of a digital computer model of the flow system, and analysis of the flow system using particle-tracking software programs. This information will help AAFB managers in making decisions about the protection and management of the ground-water resource.

\section{Study Method}

The hydrogeologic investigation at the AAFB used existing and new data and several tools to address the objectives of the study. Methods used included study of lithology and hydraulic characteristics, mapping the water table and the potentiometric surfaces of underlying aquifers, measuring stream flow, and developing a groundwater-flow model to determine flow directions and test concepts about the ground-water-flow system.

Data available from previous studies on approximately 250 wells and boreholes were gathered and entered into a computer data base to produce geologic and hydrologic maps. Regional data on the subsurface geometry and lithology of the major geologic units were refined, based on local data. Fracture traces were mapped from aerial photographs. These data were evaluated and initial concepts of the flow system were formulated. Areas where additional data were needed were identified.

Sixty-five wells were drilled by the USGS to gather additional information to help understand the flow system (fig. 2). These wells provided information necessary to define boundary conditions and supplemented geologic and hydrologic data from more localized studies within the AAFB. Borehole geophysical logs were made of 26 wells drilled into bedrock. Water samples were collected from 60 of the 65 wells for water-quality analyses. Information about these wells has been given by Haugh and others (1992).

Data from previous studies and the 65 new wells were used to map the base of the Highland Rim aquifer system and the thickness of the aquifers. The hydrogeologic maps provided detailed information for constructing a groundwater-flow model. Hydraulic conductivity values from aquifer tests and slug tests were compiled from previous investigations. The tests were analyzed to determine representative hydraulic conductivities for each aquifer.

Monthly water-levels collected by AEDC staff in approximately 220 wells within the mapped area 


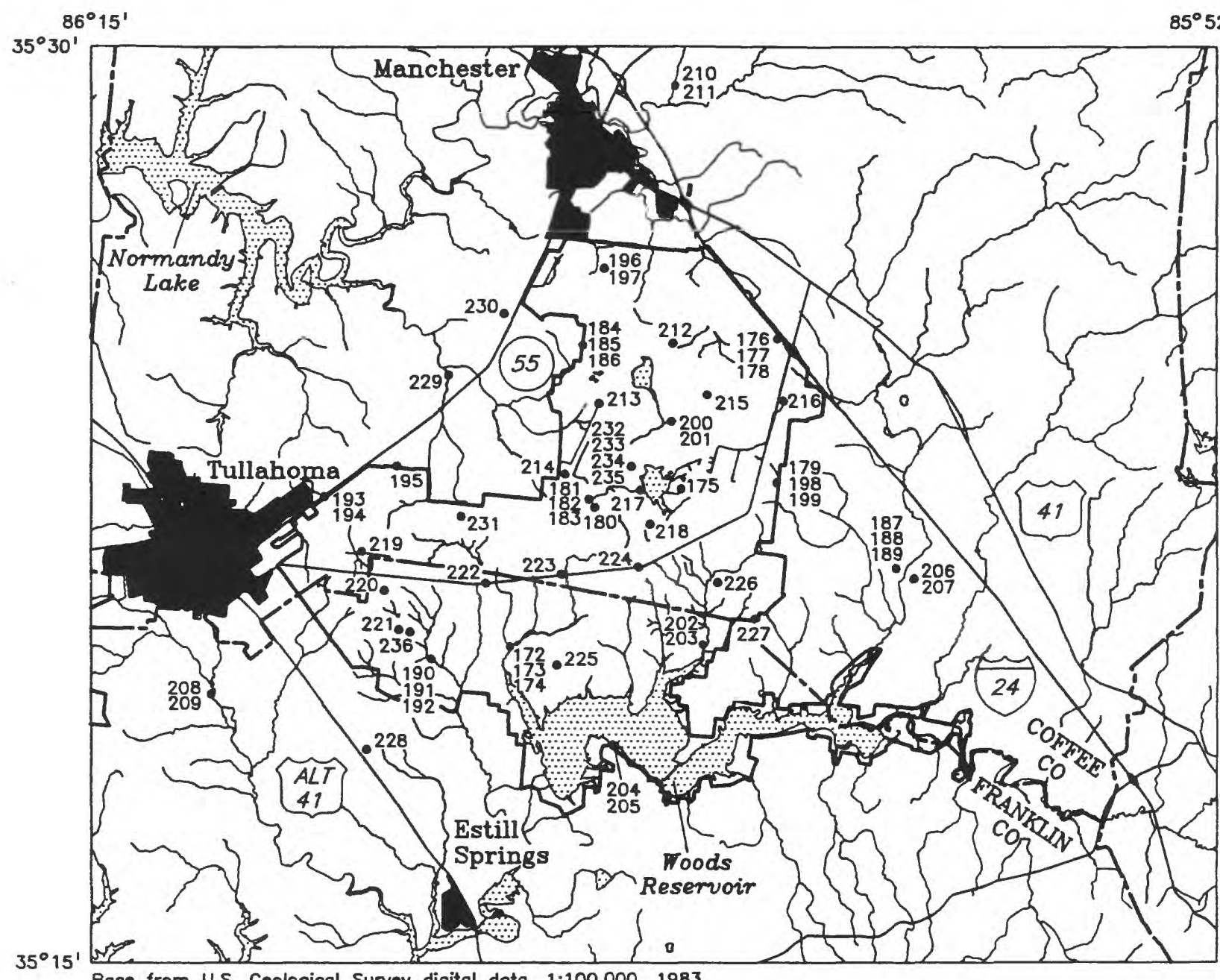

Base from U.S. Geological Survey digital data, 1:100,000, 1983

Universal Transverse Mercator projection, zone 16

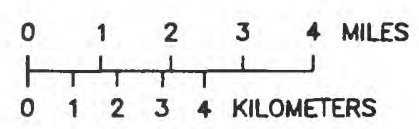

\section{EXPLANATION}

INCORPORATED TOWN

ARNOLD AIR FORCE

BASE BOUNDARY

-205 WELl LOCATION AND NUMBER

Figure 2. Location of wells installed by the U.S. Geological Survey at the Arnold Air Force Base area.

4 Hydrogeology and Simulation of Ground-Water Flow at

Arnold Air Force Base, Coffee and Franklin Counties, Tennessee 
(fig. 2) were analyzed to determine seasonal fluctuations. These data were supplemented by continuous ground-water levels collected at five sites by the USGS.

Stream discharge was measured during base flow conditions at 28 sites in November 1990. Eight of these sites were then selected for waterquality analysis and sampled in October 1991.

The geologic and hydrologic data collected for the aquifers and streamflow were then used to calibrate a computer ground-water-flow model. A post-processor, particle-tracking program was used to evaluate flow paths from three sites to develop an understanding of potential contaminant transport.

\section{Previous Studies}

Many investigations associated with site-specific ground-water contamination problems have been conducted within the AAFB area (Battelle Columbus Division, 1988, 1989a, 1989b; Battelle Denver Operations, 1989; Benham Group, 1989a, 1989b; Dames and Moore, 1975; Engineering Science, 1984; Oak Ridge National Laboratory, 1989a, 1989b; Post, Buckley, Schuh and Jernigan, Inc., 1989a, 1989b, 1989c, 1989d, 1989e, 1989f; Science Applications International Corporation, 1990; and U.S. Army Corps of Engineers, Mobile District, 1988a, 1988b). The reports of these studies contain site-specific data describing geology, lithology, well locations and construction, ground-water quality, ground-water levels, soils, aquifer-test results, land use, topography, hydrography, and water use. In general, individual reports describe one or more sites, but do not contain the entire suite of data listed above. Other sources of information include:

1. General descriptive information regarding operational and logistical facts about AEDC, prepared by Arnold Air Force Base (1989);

2. Geologic maps of the six quadrangles in the study area, published by the Tennessee Division of Geology at a scale of 1:24,000
(Hart, 1985; Moore, 1977; Miller, 1987; and Wilson, 1970, 1973, and 1976);

3. Reports on detailed studies of the same geologic formations in other locations. These studies include research describing facies sedimentology or paleoecology, or both, of the Fort Payne Formation by Ausich and Meyer (1990), Burchett and others (1980), Chowns and Elkins (1974), and Moran (1977), and the general distribution and geology of the Chattanooga Shale by Conant and Swanson (1961);

4. Reports on other studies of:

a. Water resources of the Upper Duck River Basin (Burchett, 1977);

b. Highland Rim regional aquifer system (Brahana and Bradley, 1986b);

c. Limestone hydrology of the upper Stones River Basin (Moore and others, 1969);

d. Ground-water resources and municipal water supplies of the Highland Rim (Smith, 1962);

e. Ground water in Coffee and Franklin Counties (Theis, 1936); and

f. Conceptual models of flow in the Highland Rim (Zurawski, 1978).

\section{DESCRIPTION OF STUDY AREA}

The study area includes about 180 square miles within the Normandy Lake, Manchester, Hillsboro, Tullahoma, Capital Hill, and Alto 7-1/2 minute topographic quadrangle maps. The study area was extended beyond the boundary of AAFB to include major hydrologic and physiographic features of the regional ground-water system.

Terrain in the Arnold Air Force Base area ranges from poorly drained uplands that are fairly flat to well-dissected, sloping escarpments. Altitudes of land surface within the study area range from about 890 feet above sea level along the Elk River to about 1,100 feet above sea level at the Duck River-Elk River drainage divide. Land surface altitudes rise to over 2,000 feet just east of the study area along the Cumberland Plateau escarpment (fig. 1). 


\section{HYDROGEOLOGY}

The Arnold Air Force Base area is located in the eastern part of the Highland Rim physiographic region of Tennessee (Miller, 1974). The Highland Rim is the remnant of a formerly extensive erosion surface developed on Paleozoic strata of the Nashville Basin.

\section{Geology}

The stratigraphic column underlying the AAFB area consists predominantly of impure carbonate rocks, but shales, sandstones, and conglomerates also are present. From oldest to youngest, the strata are undifferentiated formations of Upper Ordovician age, the Chattanooga Shale of Devonian and Mississippian age, and the Maury Formation, Fort Payne Formation, Warsaw Limestone, and St. Louis Limestone, all of Mississippian age (figs. 3, 4, 5, and 6). Regolith formed by weathering of the underlying bedrock occurs over most of the area. Both the Chattanooga Shale and the Fort Payne Formation crop out in the northwest section of the study area along the escarpment of the Highland Rim. In stream valleys, alluvial deposits of Quaternary age are present.

The undifferentiated formations of Upper Ordovician age consist of green-gray to blue-gray to light gray limestone, green-gray calcareous shale, mudstone and silty shale. Individual formations are difficult to identify because many have similar descriptions and characteristics. The bedrock below the Chattanooga Shale appeared during drilling to be a vertically continuous, thick, dense limestone.

The Upper Ordovician formations are unconformably overlain by the Chattanooga Shale. This formation ranges from 20 to 30 feet thick and is dark grayish black, fissile, and carbonaceous. The Chattanooga Shale is an important marker bed throughout parts of the eastern United States because it is a widespread unit and its characteristics are consistent.
The Chattanooga Shale is overlain by the Maury Formation, a thin, green shale usually less than 5 feet thick, and this unit in turn is overlain by the Fort Payne Formation. The Fort Payne Formation ranges from 20 to 230 feet thick, and regionally, consists of dark gray siltstone, and cherty limestone with thin beds of crinoidal limestone and minor amounts of shale. In most of the study area, the Fort Payne Formation appears to be a dense limestone.

Regolith derived from decay of carbonate rocks of Mississippian age is typically 10 to 90 feet thick in the AAFB area. Thickness tends to increase in the southern half of the study area. The Warsaw and St. Louis Limestones have been almost completely reduced to chert, silt, sand, gravel, and clay. Weathering of the Fort Payne Formation has occurred to irregular depths, and seems to have followed fractures in some areas. In addition, there is evidence of severe fracturing within the unit which has resulted in the development of caves and cavities ranging from 1 foot to as much as 6 feet in height. Cavities are more common in the northern part of the study area, and most contain mud, gravel, chert, and rock fragments. For the purposes of this study, the fractured rock of the upper part of the Fort Payne Formation is considered to be regolith.

The geologic structure in the AAFB area has been affected by the regional tectonic activity, and local, small-scale folding. The formations in the study area have a general regional dip toward the southeast (Wilson and Born, 1943) as a result of the tectonic uplift of the Nashville Dome. The rocks of the study area are gently dipping to nearly horizontal. Superimposed on the regional structure are local folds and flexures. Based on information from 65 wells drilled in the area for this study and recently collected data from site-specific studies at the AAFB, substantial evidence exists that a northeast-southwest trending anticline underlies the base. Pressures that formed the anticline may have influenced fracture development, and the extent and degree of interconnection of fractures undoubtedly influences the hydrogeology of the 

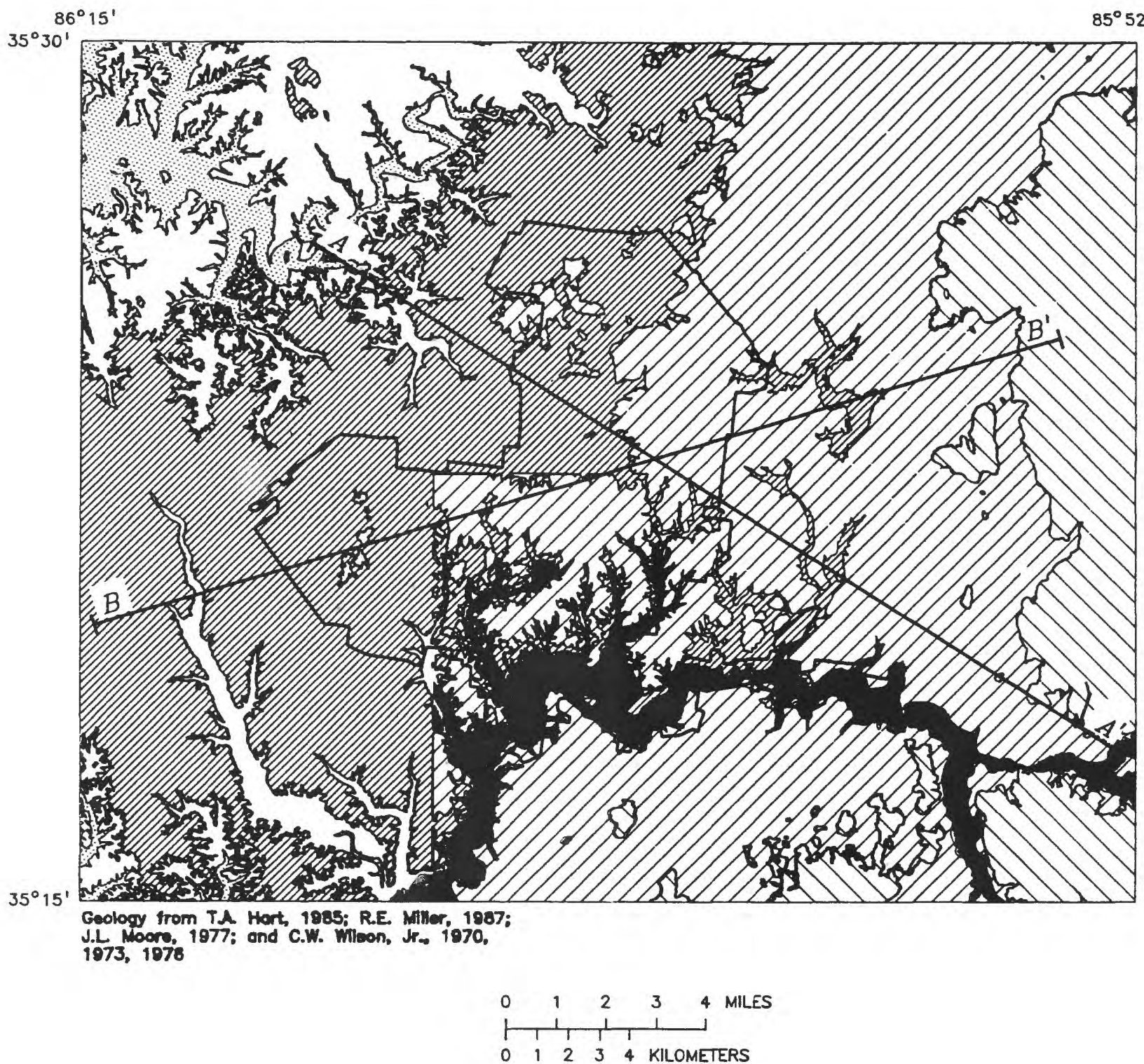

EXPLANATION

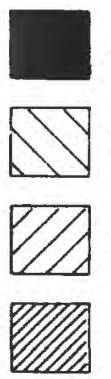

ALLUVIAL DEPOSITS

PENNSYLVANIAN-UPPER MISSISSIPPIAN FORMATIONS, UNDIFFERENTIATED

ST. LOUIS LIMESTONE

WARSAW LIMESTONE

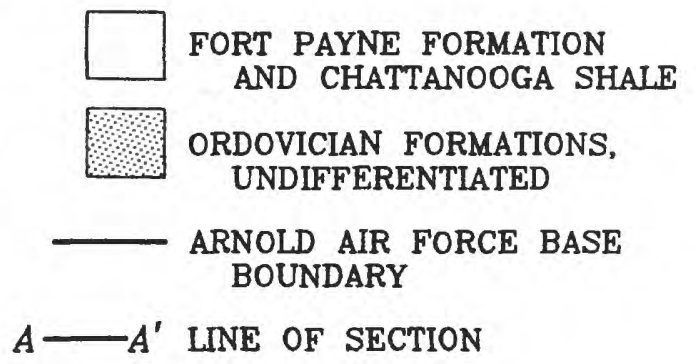

Figure 3. Geology of the Arnold Air Force Base area. 


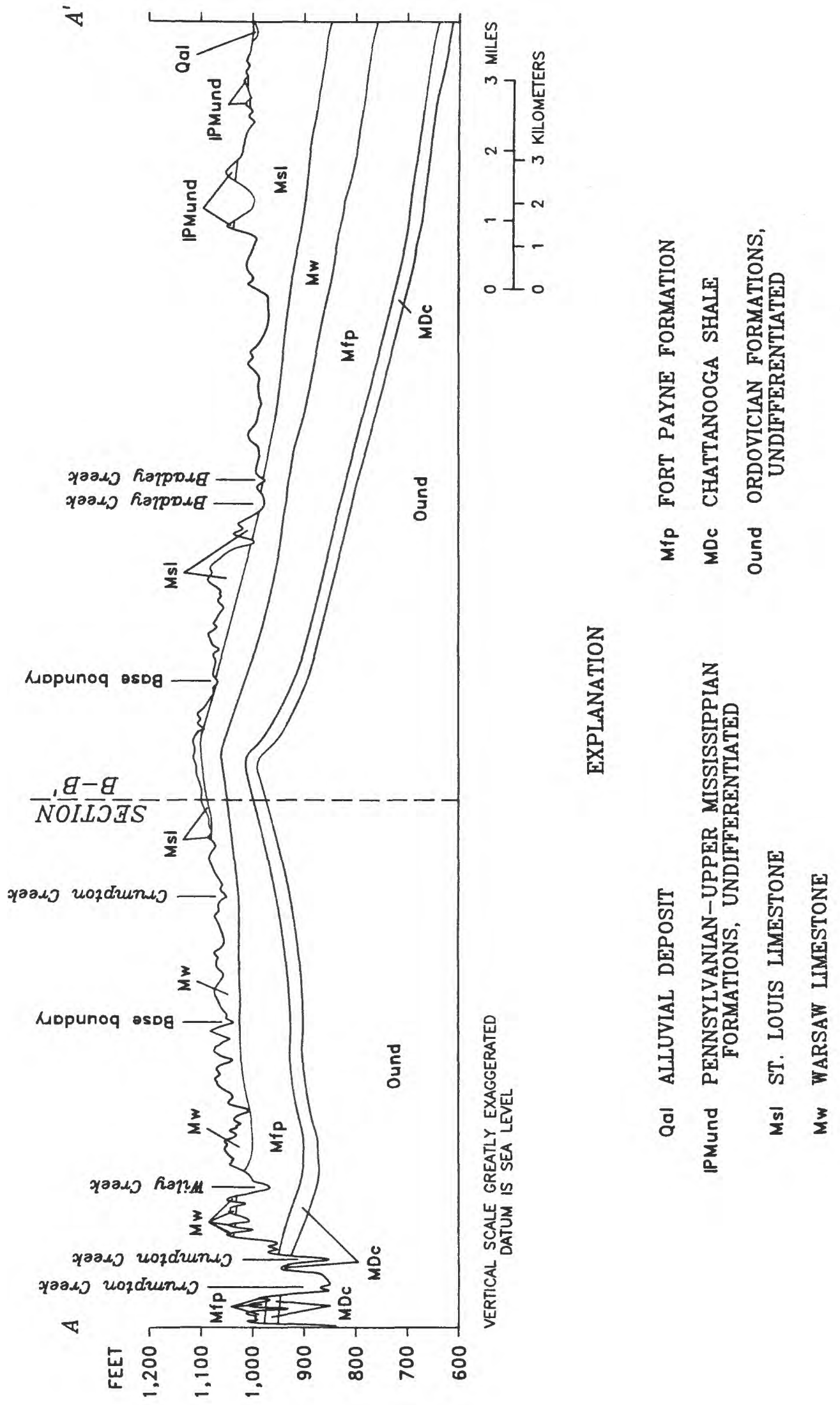

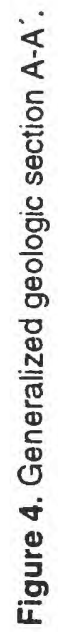

8 Hydrogeology and Simulation of Ground-Water Flow at Arnold Air Force Base, Coffee and Franklin Countles, Tennessee 
D网

$\infty$

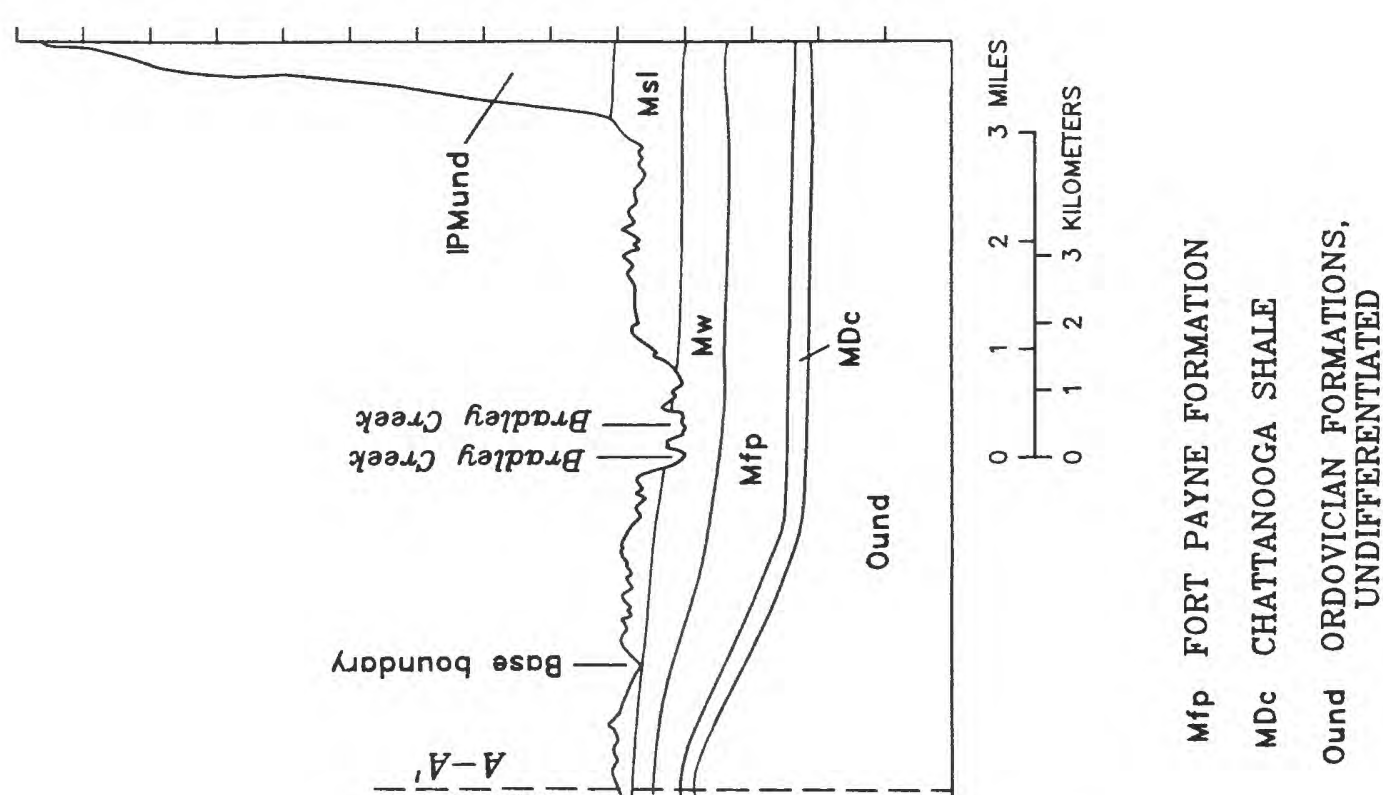

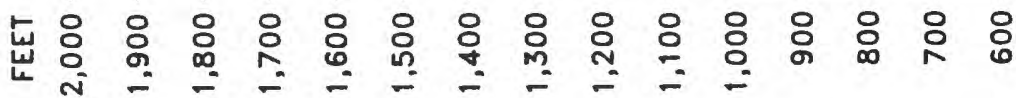

孞

要

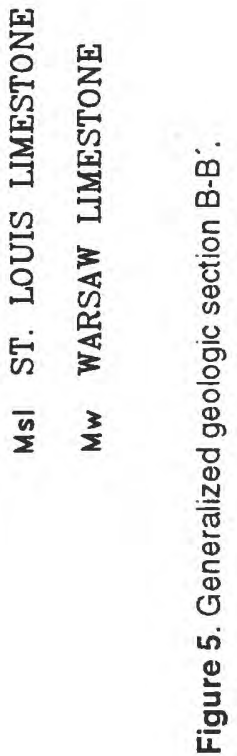




\begin{tabular}{|c|c|c|c|c|}
\hline Stratigraphy & $\begin{array}{l}\text { Thick- } \\
\text { ness of } \\
\text { unit, in }\end{array}$ & Lithology & \multicolumn{2}{|c|}{ Hydrogeologic unit } \\
\hline \multirow{2}{*}{$\begin{array}{l}\text { Regolith derived from in-situ } \\
\text { weathering of the St. Louis } \\
\text { Limestone, Warsaw Limestone } \\
\text { and/or Fort Payne Formation. }\end{array}$} & \multirow{2}{*}{$10-90$} & $\begin{array}{l}\text { Clay, silt, and sand with } \\
\text { some chert and rock } \\
\text { fragments. }\end{array}$ & \multirow{5}{*}{$\begin{array}{l}\text { Highland } \\
\text { Rim } \\
\text { aquifer } \\
\text { system }\end{array}$} & Shallow aquifer \\
\hline & & $\begin{array}{l}\text { Rock fragments, chert } \\
\text { gravel and rubble with } \\
\text { some clay. }\end{array}$ & & \\
\hline \multirow{2}{*}{ Fort Payne Formation } & \multirow{2}{*}{$20-230$} & $\begin{array}{l}\text { Fractured and solutioned } \\
\text { cherty limestone. }\end{array}$ & & \\
\hline & & $\begin{array}{l}\text { Dense, cherty limestone, } \\
\text { bedded chert and some } \\
\text { limestone. Few fractures. }\end{array}$ & & \multirow{2}{*}{ Fort Payne aquifer } \\
\hline Maury Formation & $\begin{array}{l}5 \text { or } \\
\text { less }\end{array}$ & Shale & & \\
\hline Chattanooga Shale & $20-30$ & $\begin{array}{l}\text { Dark, grayish black, } \\
\text { carbonaceous shale. }\end{array}$ & \multicolumn{2}{|c|}{ Chattanooga confining unit } \\
\hline $\begin{array}{l}\text { Ordovician formations, } \\
\text { undifferentiated. }\end{array}$ & $\begin{array}{l}\text { Greater } \\
\text { than }\end{array}$ & $\begin{array}{l}\text { Limestone, generally } \\
\text { pure, with some siltstone } \\
\text { and calcareous shale. }\end{array}$ & \multicolumn{2}{|c|}{$\begin{array}{l}\text { Upper Central Basin aquifer } \\
\text { system, undivided. }\end{array}$} \\
\hline
\end{tabular}

Figure 6. Relation of stratigraphy, lithology, and hydrogeologic units in the Arnold Air Force Base area.

10 Hydrogeology and Simulation of Ground-Water Flow at Arnold Air Force Base, Coffee and Franklin Counties, Tennessee 
area (Battelle Columbus Division, 1988, 1989a, 1989b; Battelle Denver Operations, 1989; Benham Group, 1989a, 1989b; Dames and Moore, 1975; Engineering Science, 1984; Haugh and others, 1992; Oak Ridge National Laboratory, 1989a, 1989b; Post, Buckley, Schuh and Jernigan, Inc. 1989a, 1989b, 1989c, 1989d, 1989e, 1989f; and U.S. Army Corps of Engineers, Mobile District, 1988a, 1988b).

The folding of beds and attendant stresses have resulted in the development of vertical fractures throughout the area. Fracturing occurred in response to tectonic stresses created by regional or local folding episodes. These fractures are typically vertical or nearly vertical and developed in an orthogonal pattern that defines the structural grain of the area. Fracture traces were identified as part of this investigation from low-altitude color aerial photographs of the AAFB (fig. 7). The photographs were viewed as stereographic pairs to enhance observation of the topographic features, alignment of stream channels, soil-tonal variation, or surface-depression features that identify the lineaments (Siddiqui and Parizek, 1971). The minimum length for a feature to be identified as a fracture trace was 100 feet.

A rose diagram shows the major orientation of fracture traces within the AAFB (fig. 8). The group of fractures having the highest frequency of occurrence lies between N. $50^{\circ} \mathrm{W}$. and N. $20^{\circ} \mathrm{W}$. and is centered at N. $35^{\circ} \mathrm{W}$. A secondary grouping of orthogonal fracture traces occurs between N. $40^{\circ} \mathrm{E}$. and N. $60^{\circ} \mathrm{E}$. and is centered at N. $50^{\circ} \mathrm{E}$.

Fracture traces help define structural grain in an area, particularly where hydrogeologic features may be nonhomogeneous and anisotropic. Most commonly, fracture traces represent diffuse effects from several parallel features; but in some cases, they represent a single fault or fracture. Lattman and Parizek (1964) suggest that fracture traces represent subsurface fracture zones. Preferred orientation of fracture traces, particularly where they occur as orthogonal sets, is a valuable guide in orienting the finite-difference grid of groundwater-flow models.

\section{Ground Water}

Two ground-water systems have been defined in the study area, the Highland Rim aquifer system and the upper Central Basin aquifer system (Brahana and Bradley, 1986a, 1986b). The Highland Rim aquifer system includes three main water-bearing zones. They are, from youngest to oldest, the shallow aquifer, the Manchester aquifer, and the Fort Payne aquifer. For purposes of this report, these three zones will be described as three aquifers. They differ from each other in degree of weathering, amount of chert, and type of weathering product, but are not separated by confining units. Thus, water is free to flow between these zones or aquifers. The Chattanooga Shale is at the base of this flow system and functions as an underlying confining unit (fig. 6). The upper Central Basin flow system consists of units below the Chattanooga Shale. The potential for flow through the confining unit appears to be small if existent at all. This investigation and report focus on flow in the Highland Rim aquifer system. The upper Central Basin aquifer system is not a major water-bearing unit within the study area.

\section{Regional Flow Boundaries}

A ground-water divide, approximately coinciding with the Duck River-Elk River surfacewater divide, underlies the AAFB facility and extends from southwest to northeast. Ground water flows from the divide area to the discharge areas, which are the major streams, lakes, and reservoirs around the base. These regional discharge areas define the lateral extent of the ground-waterflow system at AAFB. Moving counterclockwise from the northeastern corner of the study area (fig. 9), the lateral boundaries of the system are:

1. Roan Buck Branch, from the head to the confluence with Wolf Creek;

2. Wolf Creek, from the confluence with Roan Buck Branch to the confluence with Little Duck River;

3. Little Duck River, from the confluence with Wolf Creek to the Chattanooga Shale outcrop at Little Falls; 

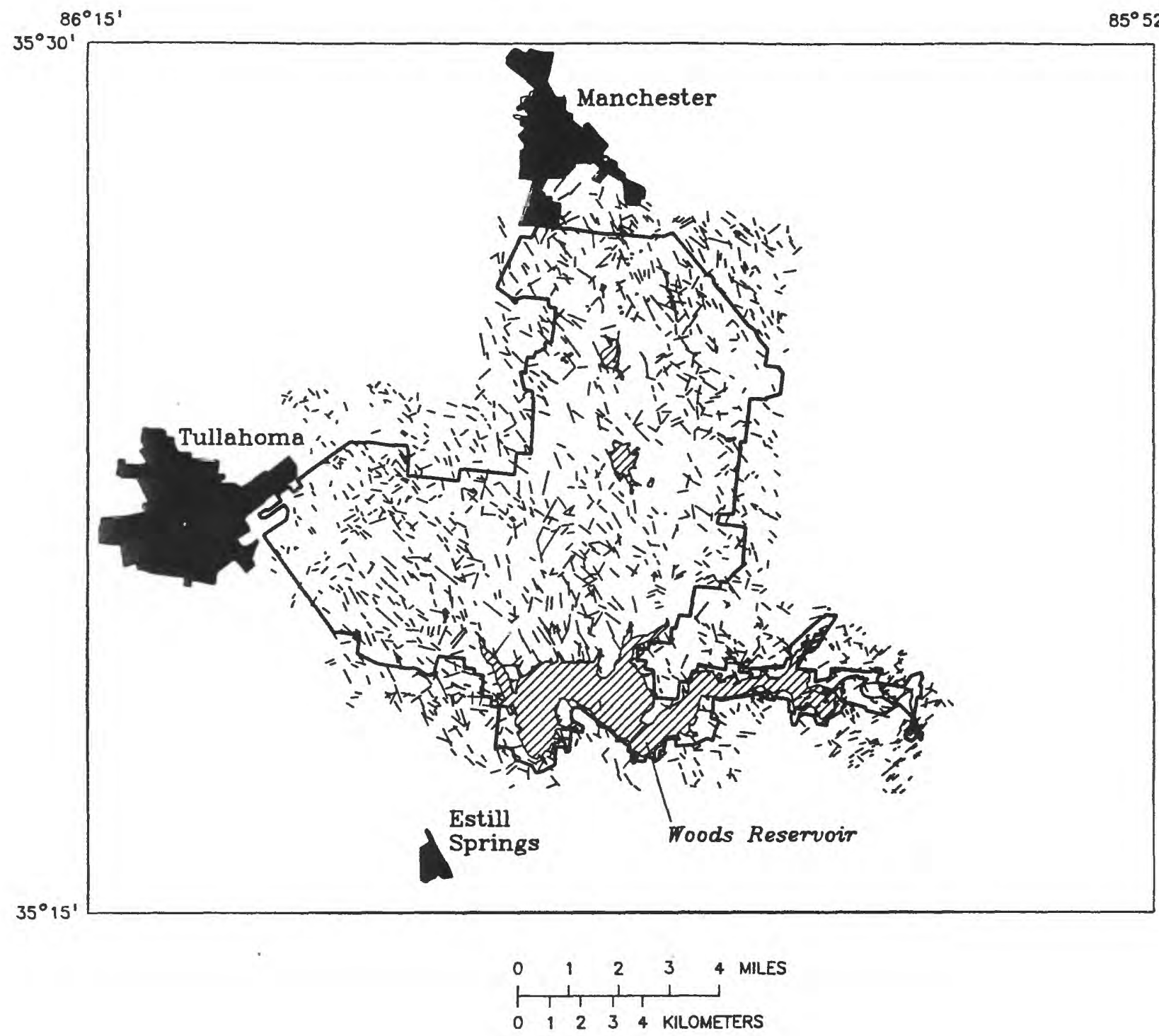

\section{EXPLANATION}

INCORPORATED TOWN

ARNOLD AIR FORCE BASE BOUNDARY

FRACTURE TRACE--Orientation

mapped from aerial photographs

Figure 7. Fracture traces mapped from aerial photographs of Arnold Air Force Base.

12 Hydrogeology and Simulation of Ground-Water Flow at Arnold Air Force Base. Coffee and Franklin Counties, Tennessee 


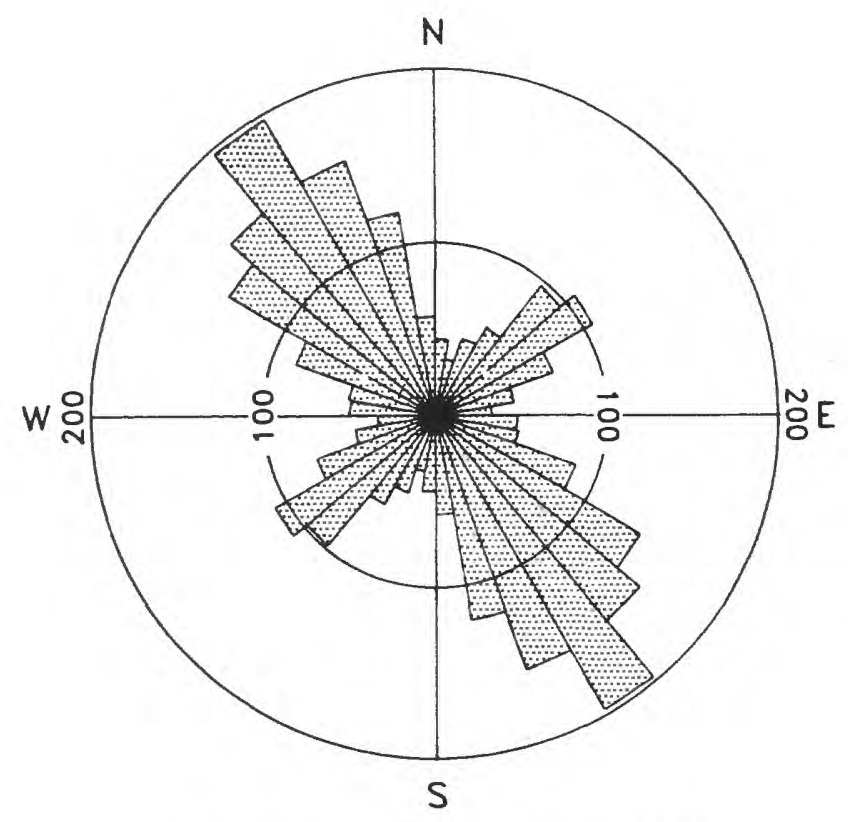

Number of observations $=1,563$
Frequency of observation shown by length of radius for that bearing

Figure 8. Rose diagram showing frequency and orientation of fracture traces at Arnold Air Force Base.

4. the Highland Rim escarpment from the Little Falls on the Little Duck River to Ovoca Falls on Carroll Creek;

5. Carroll Creek, from the Chattanooga Shale outcrop at Ovoca Falls to the head;

6. an imaginary flow line from the head of Carroll Creek to the Duck River-Elk River drainage divide, normal to the divide;

7. another imaginary flow line from the Duck River-Elk River drainage divide, normal to the divide to the head of an unnamed creek;

8. the unnamed creek, from the head to the confluence with the North Fork Rock Creek;

9. North Fork Rock Creek, from the confluence with the unnamed creek to the confluence with Rock Creek;

10. Rock Creek, from the confluence with North Fork Rock Creek to the mouth at Tims Ford Lake;

11. Tims Ford Lake, from the mouth of Rock Creek to the mouth of the Elk River;
12. the Elk River, from the mouth at Tims Ford Lake to Woods Reservoir;

13. Woods Reservoir, from the outlet point to the Elk River to the mouth of Bradley Creek;

14. Bradley Creek, from the mouth at Woods Reservoir to the confluence with Blue Spring Creek;

15. Blue Spring Creek, from the confluence with Bradley Creek to the confluence with Warren Branch;

16. Warren Branch, from the confluence with Blue Spring Creek to the head;

17. an imaginary flow line from the head of Warren Branch to the Duck River-Elk River drainage divide, normal to the divide; and

18. a final imaginary flow line from the Duck River-Elk River drainage divide, normal to the divide to the head of Roan Buck Branch.

To verify and document that these streams are discharge boundaries for the hydrologic system, 


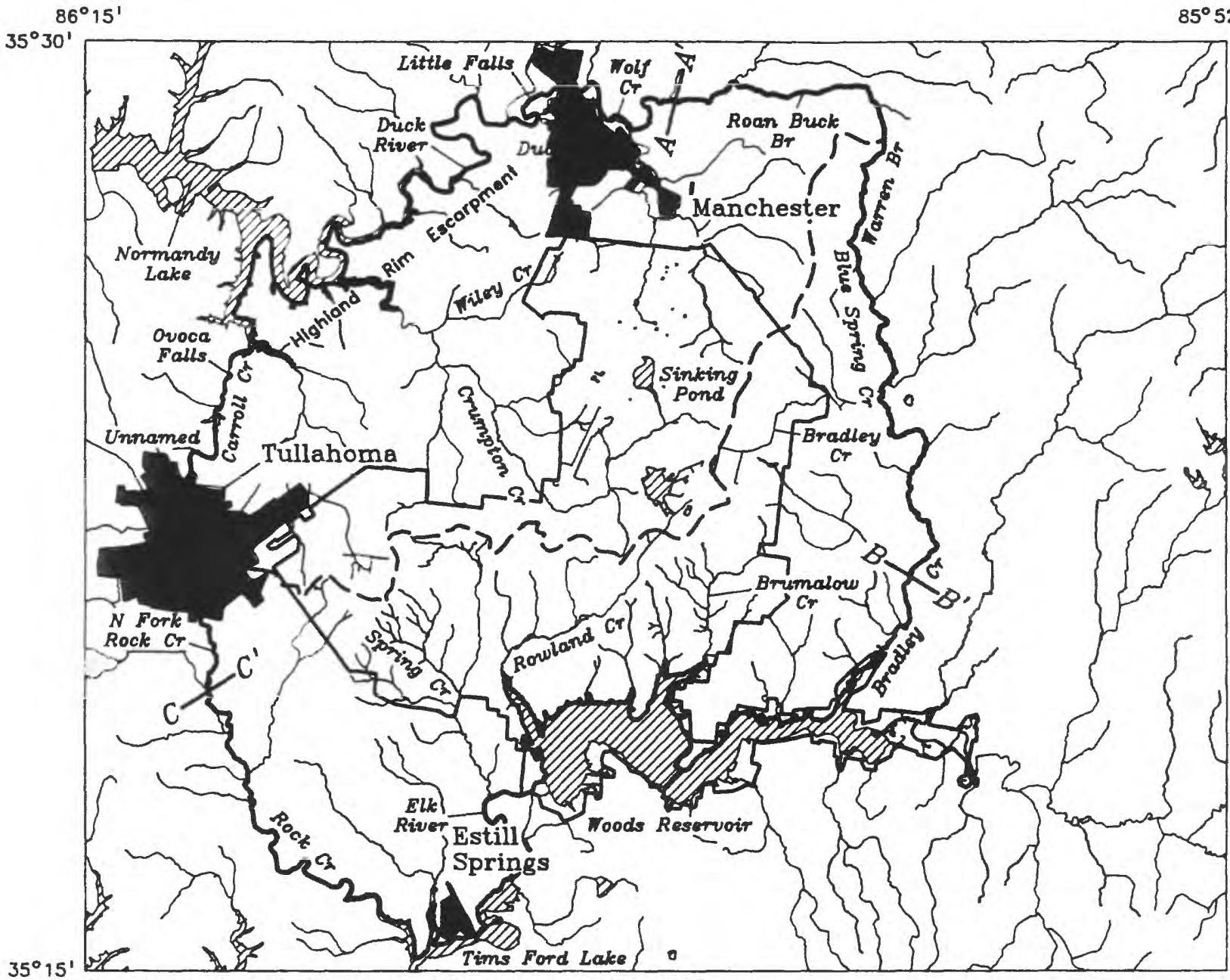

Base from U.S. Geological Survey digital doto, 1:100,000, 1983

Universal Transverse Mercotor projection, zone 16

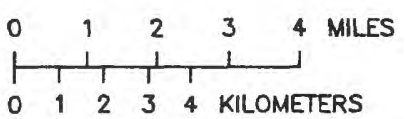

\section{EXPLANATION}
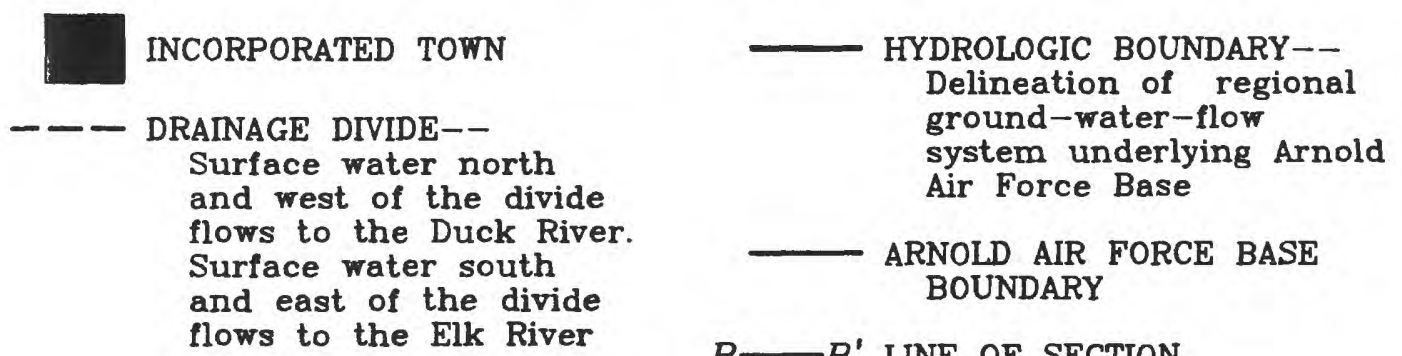

$B-B^{\prime}$ LINE OF SECTION

Figure 9. Regional flow boundaries and location of hydrogeologic sections at the Arnold Air Force Base area.

14 Hydrogeology and Simulation of Ground-Water Flow at

Arnold Air Force Base, Coffee and Franklin Counties, Tennessee 
well clusters were installed north of Wolf Creek, east of Bradley Creek, and southwest of Rock Creek. Each of these locations is approximately 1,000 feet across the hydrologic boundary. Waterlevel data at each location indicate that no underflow occurs beneath the boundary streams as the gradients are always toward the boundary stream.

At Wolf Creek along the northern boundary, water levels show an upward gradient within the Highland Rim flow system of approximately 4 feet and water levels in both wells of this cluster are near or above the river stage altitude of Wolf Creek (fig. 10). At Bradley Creek along the eastern boundary, a well cluster was installed on each side of the stream. Water-level altitudes in the deeper wells in the Highland Rim flow system on both sides of the stream are about 5 feet above river stage altitude, indicating that ground water flows to the stream from both directions (fig. 11). At Rock Creek along the southwestern boundary, although the water levels indicate a downward gradient within the Highland Rim flow system, the water levels are 8 to 15 feet above the river stage altitude, indicating that ground water flows toward the stream (fig. 12). No ground water is assumed to flow beneath the rivers across these boundaries.

Water levels of Woods Reservoir and Tims Ford Lake remain constant throughout the year on the southern side of the study area. At the northwestern boundary, numerous seeps and springs drain the ground-water system where the Chattanooga Shale crops out along the Highland Rim escarpment.

\section{Recharge}

Recharge to the aquifers is from precipitation. In a study by Hoos (1990), recharge rates for drainage basins across Tennessee were estimated using a hydrograph-separation technique (Rorabough, 1964; Daniel, 1976). Reported average annual recharge rates for drainage basins in the Highland Rim area ranged from 4.9 to 9.8 inches. Parts of the drainage basins for two stations studied by Hoos lie within the AAFB study area. The hydrograph-separation technique was applied to records for years of average, high, and low rainfall. Rainfall during the average year was the median value for all years of record, and rainfall during the high and low years were the values for years that represented the extremes during the years of record. Calculated annual recharge rates for the Duck River downstream from Manchester were 10.1, 9.8, and 4.0 inches for high (1974), average (1965), and low (1981) years, respectively. Annual precipitation at the Duck River downstream from Manchester during the average year was 45.08 inches. Net annual recharge rates for the Elk River near Pelham were 11.0, 8.8, and 4.3 inches for high (1973), average (1972), and low (1981) years, respectively. Annual precipitation at the Elk River during the average year was 67.59 inches. Data collected at the AAFB recorded 57.17 inches of precipitation for the water year 1991.

\section{Aquifers}

Hydraulic conductivity data are available from approximately 40 slug tests and 8 aquifer tests on wells in the Highland Rim aquifers (Battelle Columbus Division, 1988, 1989a, 1989b; Battelle Denver Operations, 1989; Benham Group, 1989a, 1989b; Burchett, 1977; Dames and Moore, 1975; Engineering Science, 1984; Oak Ridge National Laboratory, 1989a, 1989b; Post, Buckley, Schuh and Jernigan, Inc., 1989a, 1989b, 1989c, 1989d, 1989e, 1989f; Science Applications International Corporation, 1990; U.S. Army Corps of Engineers, Mobile District, 1988a, 1988b; and Woodward-Clyde Consultants, 1990). Values range from 0.02 to $84 \mathrm{ft} /$ day. The highest conductivities are reported for the shallow and Manchester aquifers. No hydraulic conductivity data are available in the study area for the upper Central Basin aquifer system, but drilling records and geophysical logs indicate that no significant permeable zones were found in the six wells drilled for this study. In fact, water levels in five of these wells took months to recover after sampling.

The shallow aquifer consists of silt and clay, rock fragments, and minor amounts of chert. Ground water occurs under water-table conditions and may be perched in some locations. Based on 


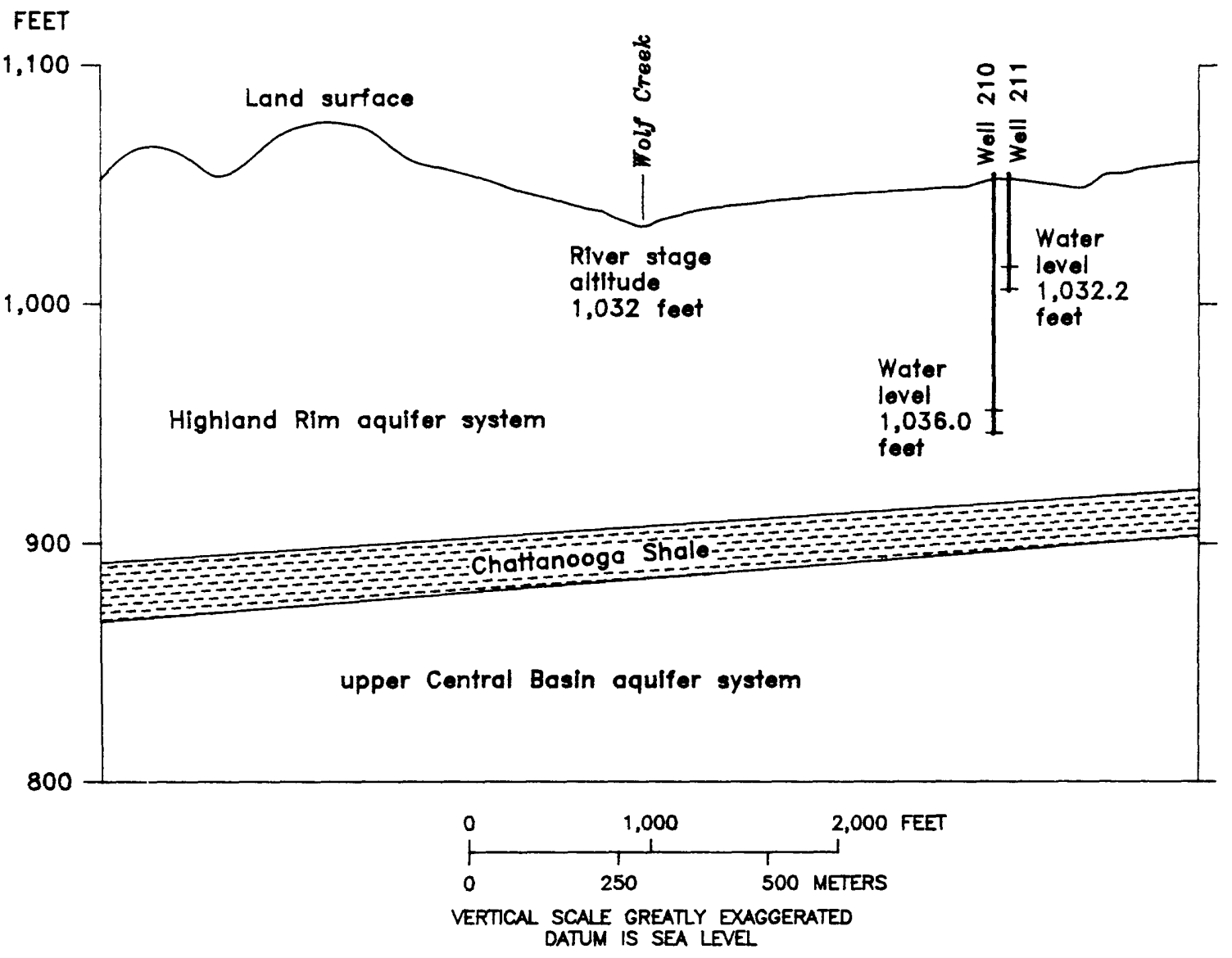

Figure 10. Generalized hydrogeologic section $A-A^{\prime}$ along northern flow boundary at Wolf Creek. 
$B$

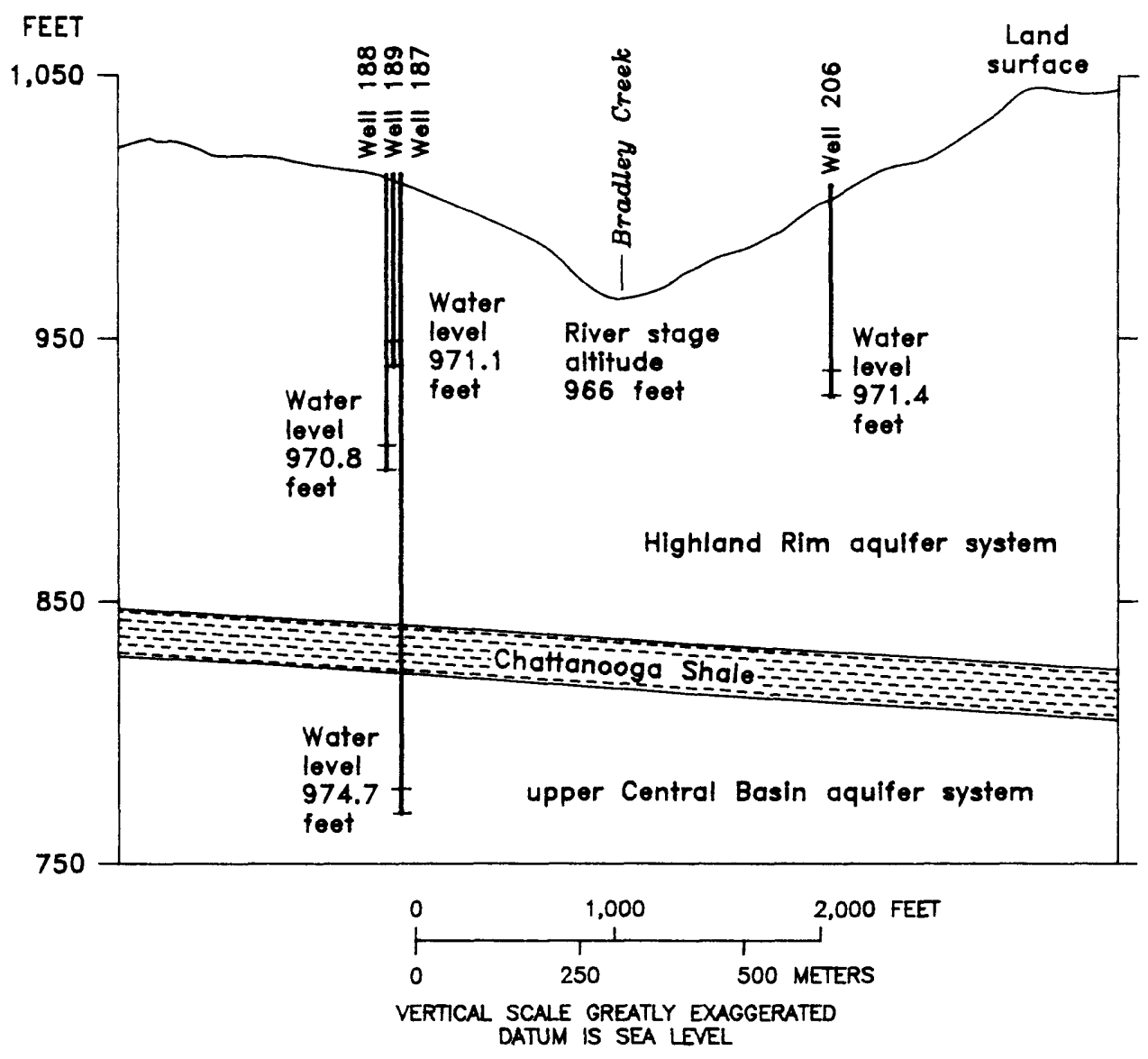

Figure 11. Generalized hydrogeologic section B-B' along eastern flow boundary at Bradley Creek. 
FEET

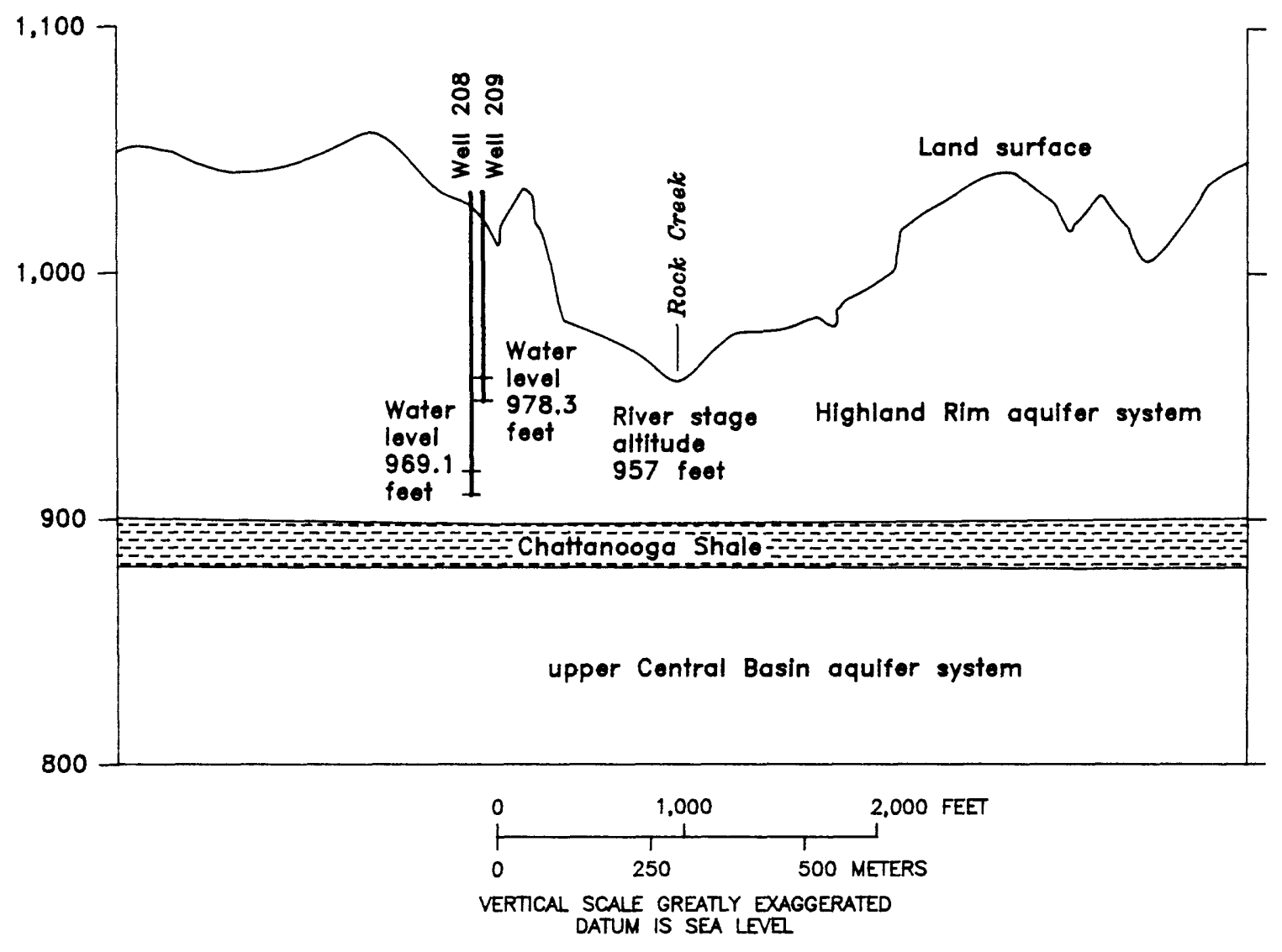

Figure 12. Generalized hydrogeologic section $C^{-} C^{\prime}$ along southwestern flow boundary at Rock Creek.

18 Hydrogeology and Simulation of Ground-Water Flow at

Arnold Air Force Base, Coffee and Franklin Counties, Tennessee 
17 measurements, hydraulic conductivity within the shallow aquifer ranges from 0.9 to $18 \mathrm{ft} /$ day with a median value of $9 \mathrm{ft} /$ day. The thickness of the shallow aquifer ranges from 5 to 75 feet.

The Manchester aquifer supplies most domestic wells in the area. The aquifer consists of waterbearing chert rubble and solution openings and fractures in the bedrock of the Fort Payne Formation (Burchett and Hollyday, 1974). Ground water in this aquifer occurs under confined conditions in areas where fine-grained material in the shallow aquifer serves as a leaky confining unit. Fractures trending northeast-southwest and northwestsoutheast create a fracture-flow system within the lower part of the Manchester aquifer. Based on 24 measurements, hydraulic conductivity ranges from 0.1 to $69 \mathrm{ft} /$ day with a median value of $28 \mathrm{ft} /$ day. The Manchester aquifer ranges in thickness from 5 to 50 feet.

The Fort Payne aquifer consists of dense limestone that ranges in thickness from 20 to 230 feet. Based on 10 measurements, the hydraulic conductivity ranges from 0.02 to $8.6 \mathrm{ft} /$ day with a median value of $1.6 \mathrm{ft} / \mathrm{day}$. Specific-capacity tests were conducted on six wells open to the Fort Payne aquifer. Specific capacities ranged from 0.32 to $82 \mathrm{gal} / \mathrm{min} / \mathrm{ft}$. The high value is an anomalous value indicating that perhaps the water was coming --from the overlying Manchester aquifer. Eliminating the high value, the range of values for the five remaining specific-capacity tests is 0.32 to $2.3 \mathrm{gal} / \mathrm{min} / \mathrm{ft}$. Transmissivities computed from specific-capacity data range from 70 to 600 feet squared per day.

\section{Flow Directions}

Regionally, ground water flows from the ground-water divide towards places of discharge which are the rivers and lakes of the area (fig. 13). Near the divide, a downward vertical component of ground-water flow exists within the Highland Rim aquifer system. In the shallow and Manchester aquifers, substantial localized flow also occurs toward the streams and other surface-water bodies.

Flow within the Manchester aquifer is more complex than in the shallow aquifer and the Fort Payne aquifer because of preferred pathways of flow provided by fractures and solution channels. Because the location of these features is generally unknown, only areal flow directions based on differences in hydraulic head in this aquifer can be assumed.

Locally, water flows to the $\mathrm{J} 4$ test cell from all directions because water in the aquifers immediately surrounding the cell is continuously drained through a network of six wells. The cone of depression in the potentiometric surface of the Manchester aquifer at the test cell shows anisotropic features that are believed to result from preferential dewatering along zones of higher permeability. These zones have developed within fractures and solution channels. Because all of the Highland Rim aquifers are interconnected, these features are also seen in the shallow and Fort Payne aquifers (fig. 14). Even after drilling into the Manchester aquifer, the distribution and extent of fractures is difficult to delineate.

The flow of water is negligible through the dense limestone that constitutes the Fort Payne aquifer. The little flow that does occur has direct hydraulic connection to flow in the Manchester aquifer.

\section{Water Levels}

Natural seasonal flunctuations of the water table are related to seasonal changes in precipitation, evapotranspiration, and thus, to changes in groundwater recharge. Ground-water levels are normally highest during the spring months following the winter period of high precipitation and low evapotranspiration. Water levels recede during the summer in response to diminishing precipitation and high evapotranspiration, and are at the lowest levels in the fall. Hydrographs of wells at the AAFB exhibit these characteristic seasonal 


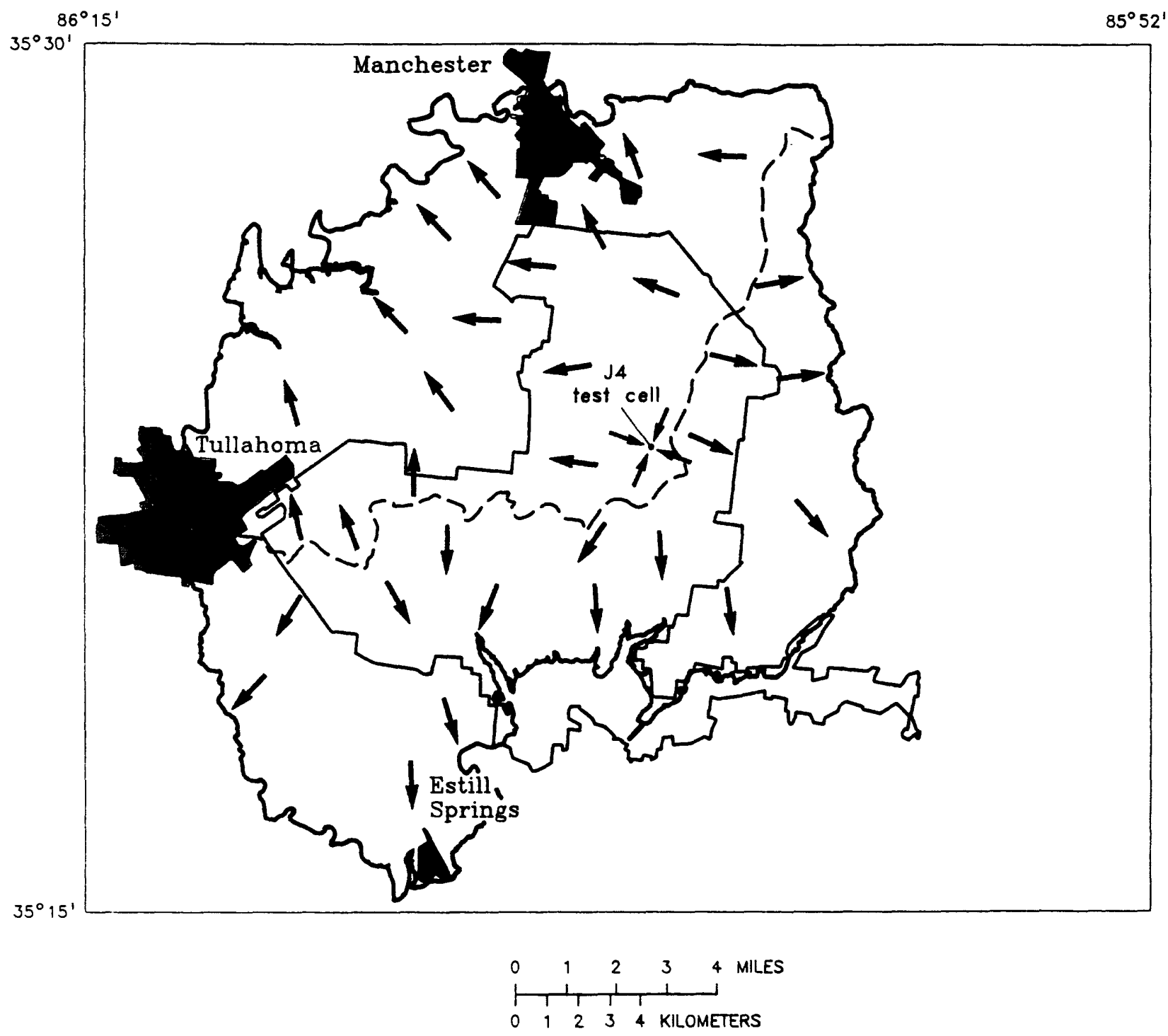

EXPLANATION

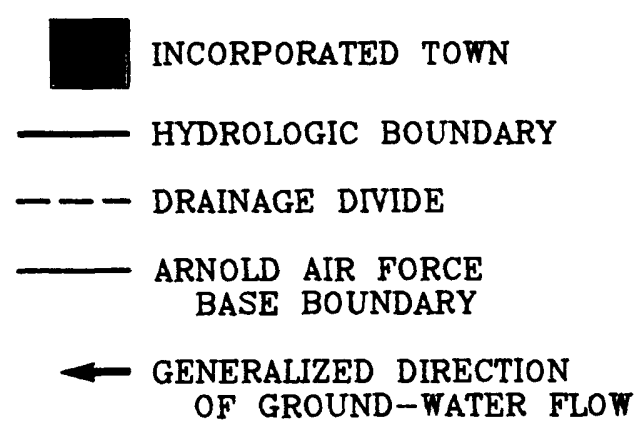

Figure 13. Generalized directions of regional ground-water flow in the study area, fall 1989.

20 Hydrogeology and Simulation of Ground-Water Flow at

Arnold Air Force Base, Coffee and Franklin Counties, Tennessee 


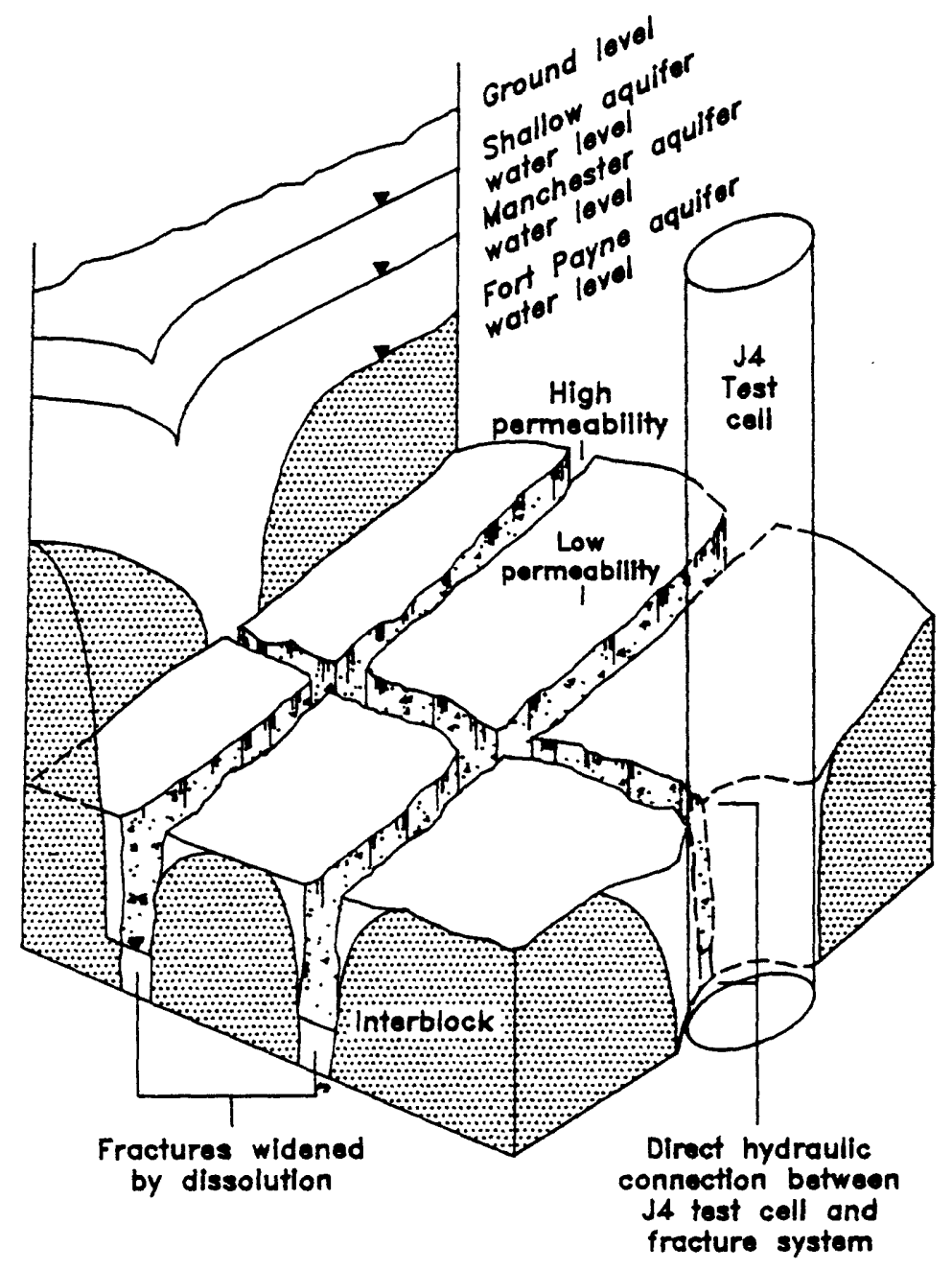

Figure 14. Hypothesis of secondary permeability in the Manchester aquifer and the effects of dewatering at the $\mathrm{J} 4$ test cell on water levels in the shallow, Manchester, and Fort Payne aquifers at Arnold Air Force Base. 
variations (figs. 15-22) (See figure 2 for location of wells).

Seasonal water-level fluctuations ranged from less than 1 foot to as much as 25 feet during the 20-month measurement period from May 1991 to December 1992. In general, the largest fluctuations are observed in wells along the divide, particularly in the wetland areas in the northern part of the AAFB (figs. 15, 16, and 17). Water levels in most well clusters show a downward vertical gradient with the largest gradient in well clusters near the divide (figs. 18, 19, and 20). Water levels in wells near the boundaries show much smaller seasonal fluctuations, usually less than 5 feet, and smaller vertical gradients that usually are upwards (figs. 21 and 22). These variations have been observed in all of the aquifers.

Contour maps of water levels for the shallow, Manchester, and Fort Payne aquifers show an anisotropic water-level depression centered on the J4 test cell because of the dewatering activities at the J4 test cell. This anisotropy is related to the fracturing in the lower part of the Manchester aquifer.

\section{Water Quality}

Water-quality samples were collected from 60 wells at Arnold Air Force Base. Samples were analyzed for major inorganic constituents, trace metals, and volatile organic compounds. Sampling procedures and complete analytical results are published in Haugh and others (1992).

\section{Inorganic constituents}

Chemical analyses of water and geochemical interpretations provide additional insight in understanding the ground-water-flow system. The water-quality data show variations in the water chemistry between the various aquifers. Trilinear diagrams and boxplots displaying concentrations of dissolved solids, sulfate, chloride, and lithium illustrate the geochemical differences between the aquifers.
A trilinear diagram shows that water from the shallow aquifer is predominantly of the calcium bicarbonate type (fig. 23). Similarly, most water from the Manchester aquifer is also of the calcium bicarbonate type, but some of the water is of the mixed cation or sodium dominant type (fig. 24). Most water from the Fort Payne aquifer is of the calcium bicarbonate sulfate type, but again, some is of a mixed cation type (fig. 25). Water from the upper Central Basin aquifer is of the sodium sulfate chloride type with the exception of the water sample from one well, which shows bicarbonate as the dominant anion (fig. 26).

Dissolved solids concentrations for all aquifers ranged from 11 to $8,810 \mathrm{mg} / \mathrm{L}$. The range and median values of dissolved solids for each aquifer are as follows: shallow aquifer, 19 to $105 \mathrm{mg} / \mathrm{L}$, $60 \mathrm{mg} / \mathrm{L}$; Manchester aquifer, 11 to $172 \mathrm{mg} / \mathrm{L}$, $48 \mathrm{mg} / \mathrm{L}$; Fort Payne aquifer, 244 to $4,100 \mathrm{mg} / \mathrm{L}$, $1,235 \mathrm{mg} / \mathrm{L}$; and upper Central Basin aquifer, 315 to $8,810 \mathrm{mg} / \mathrm{L}, 1,712 \mathrm{mg} / \mathrm{L}$. These results are displayed graphically as boxplots (fig. 27). Similar variations in sulfate, chloride, and lithium concentration can be observed between the aquifers (figs. 28, 29, and 30). The range and median values of selected constituents are shown in table 1 .

The low dissolved solids concentrations in water from the shallow and Manchester aquifers indicate that ground water flows through these aquifers relatively fast and that time of residence is short. It also indicates that the most soluble minerals in the aquifer matrix have already been dissolved and removed from the system. In the lower part of the Manchester aquifer, circulation is through fractures in the rock where travel paths may be somewhat longer, but the rate of flow is sufficiently fast and the amount of aquifer surface area available to react with water is smaller, and consequently, concentrations are low. In both the shallow and Manchester aquifers bicarbonate is the principal anion:

The higher dissolved-solids concentrations in water from the Fort Payne aquifer reflect deeper, slower, circulation of ground water through the 


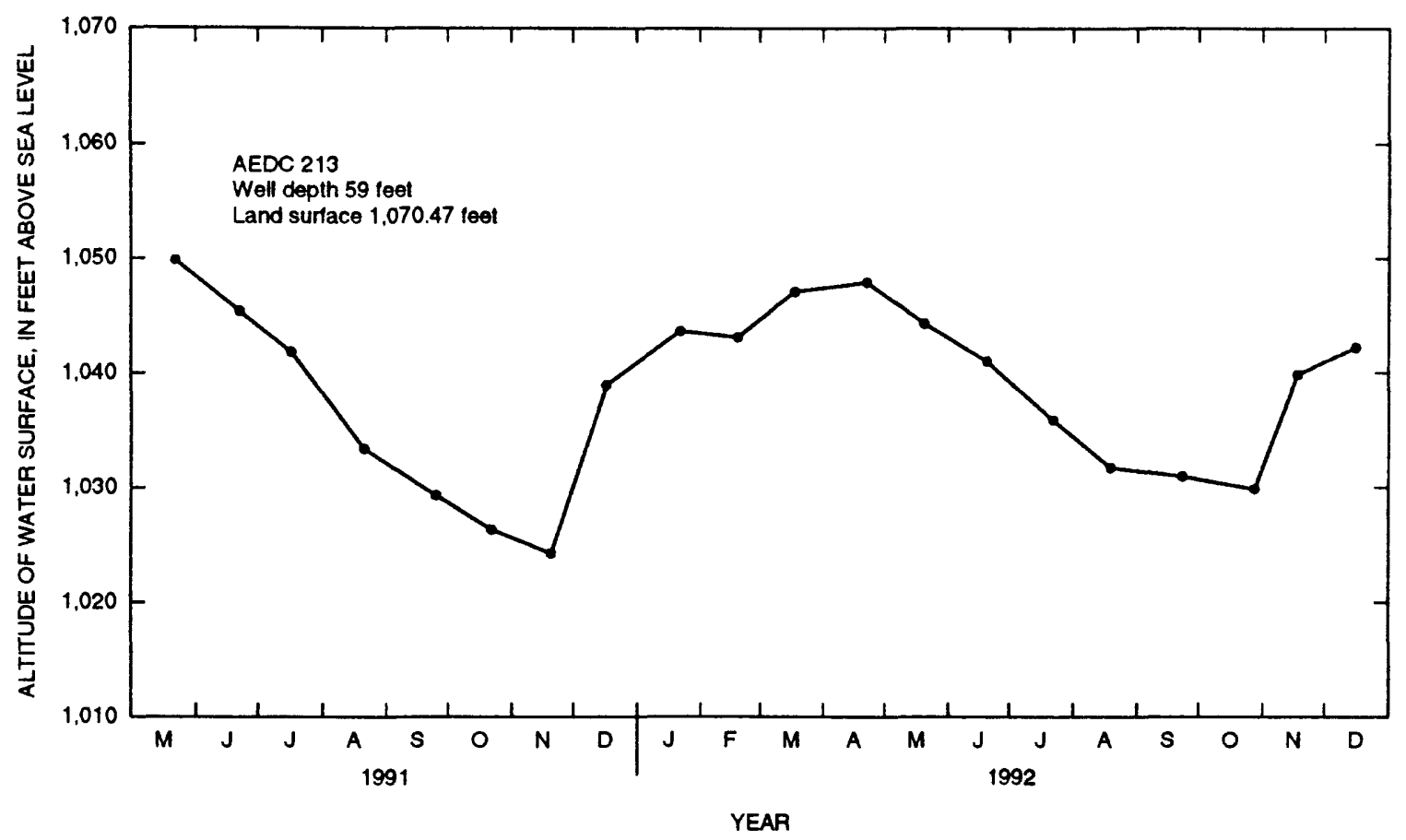

Figure 15. Water levels in well AEDC 213 from May 1991 through December 1992.

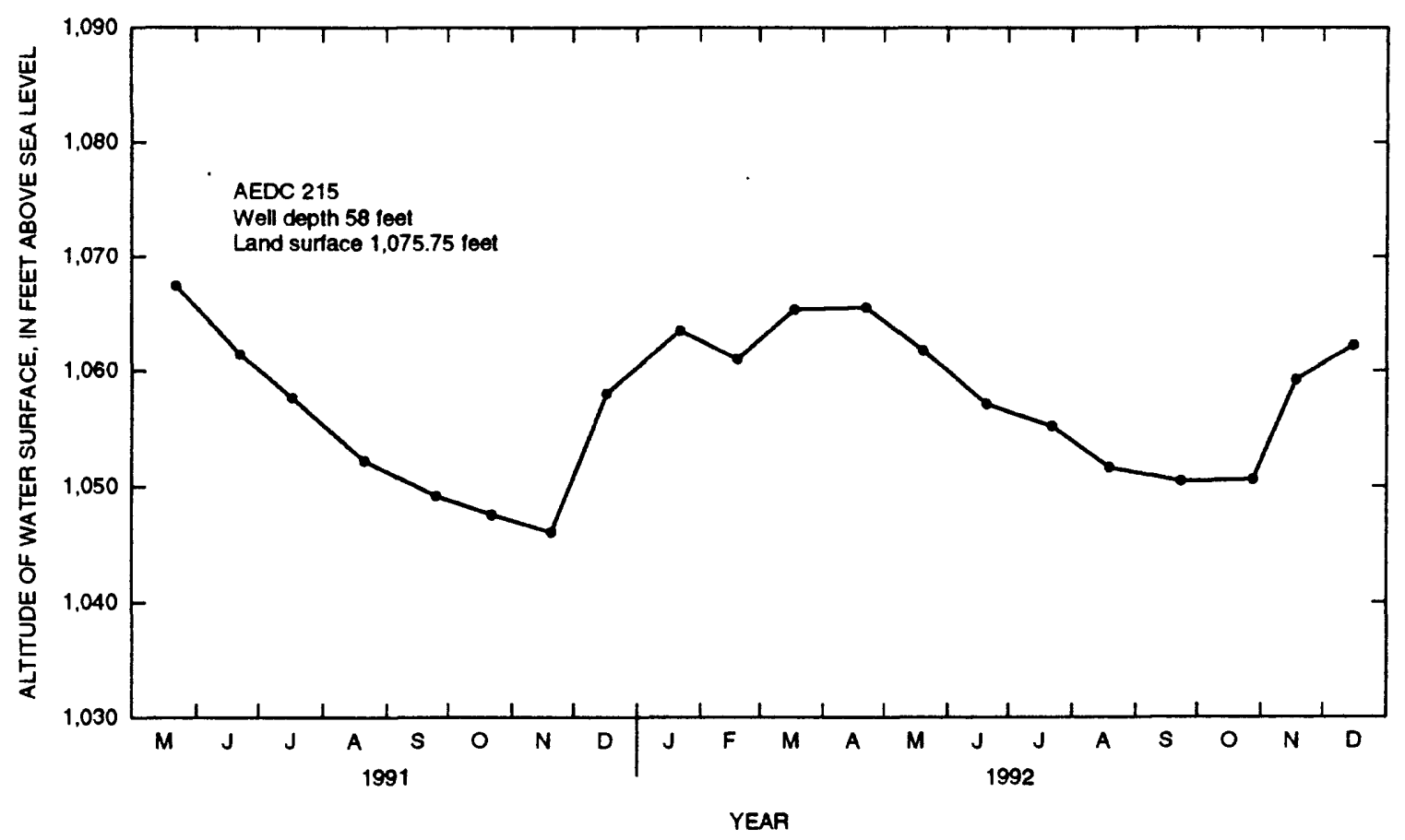

Figure 16. Water levels in well AEDC 215 from May 1991 through December 1992. 


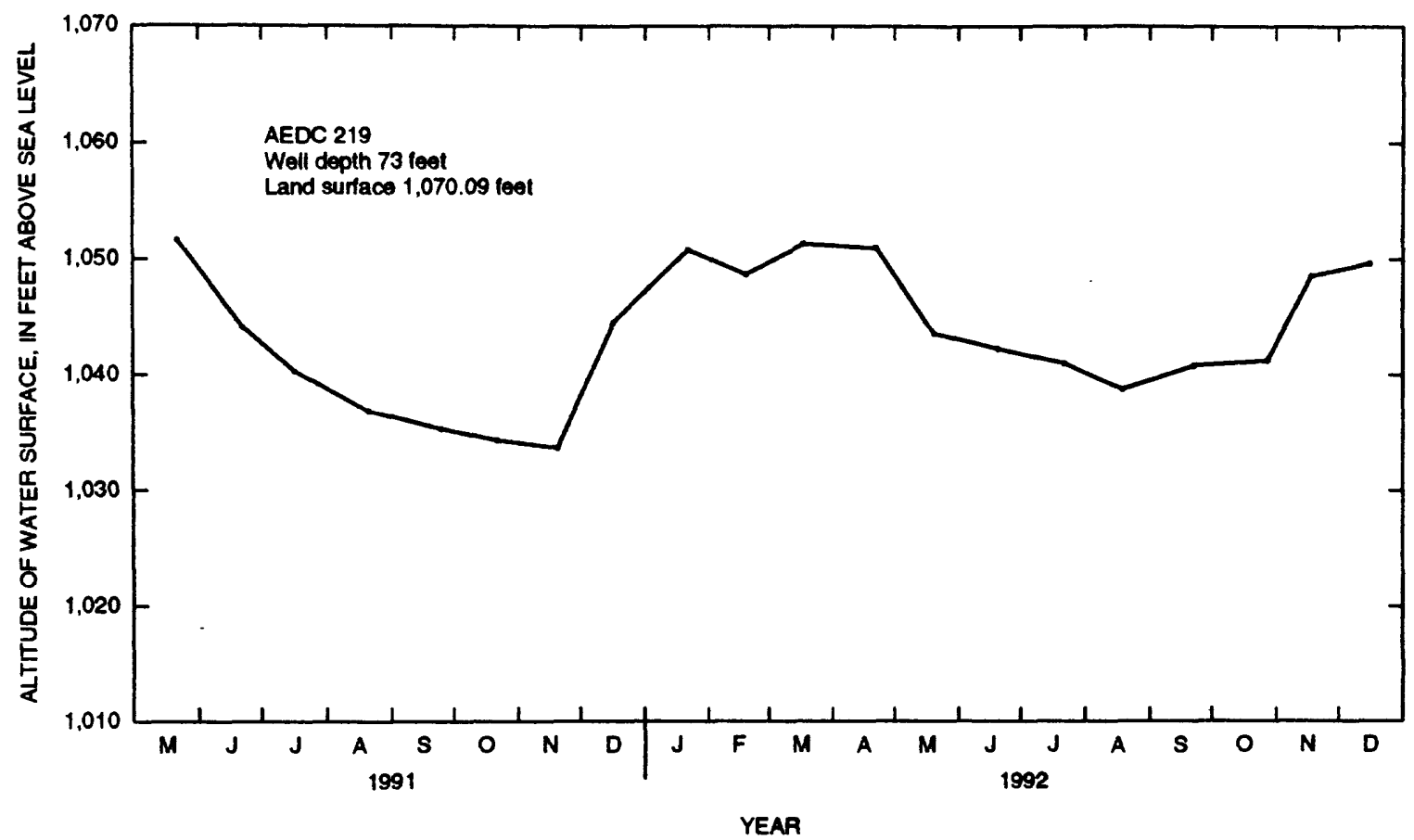

Figure 17. Water levels in well AEDC 219 from May 1991 through December 1992.

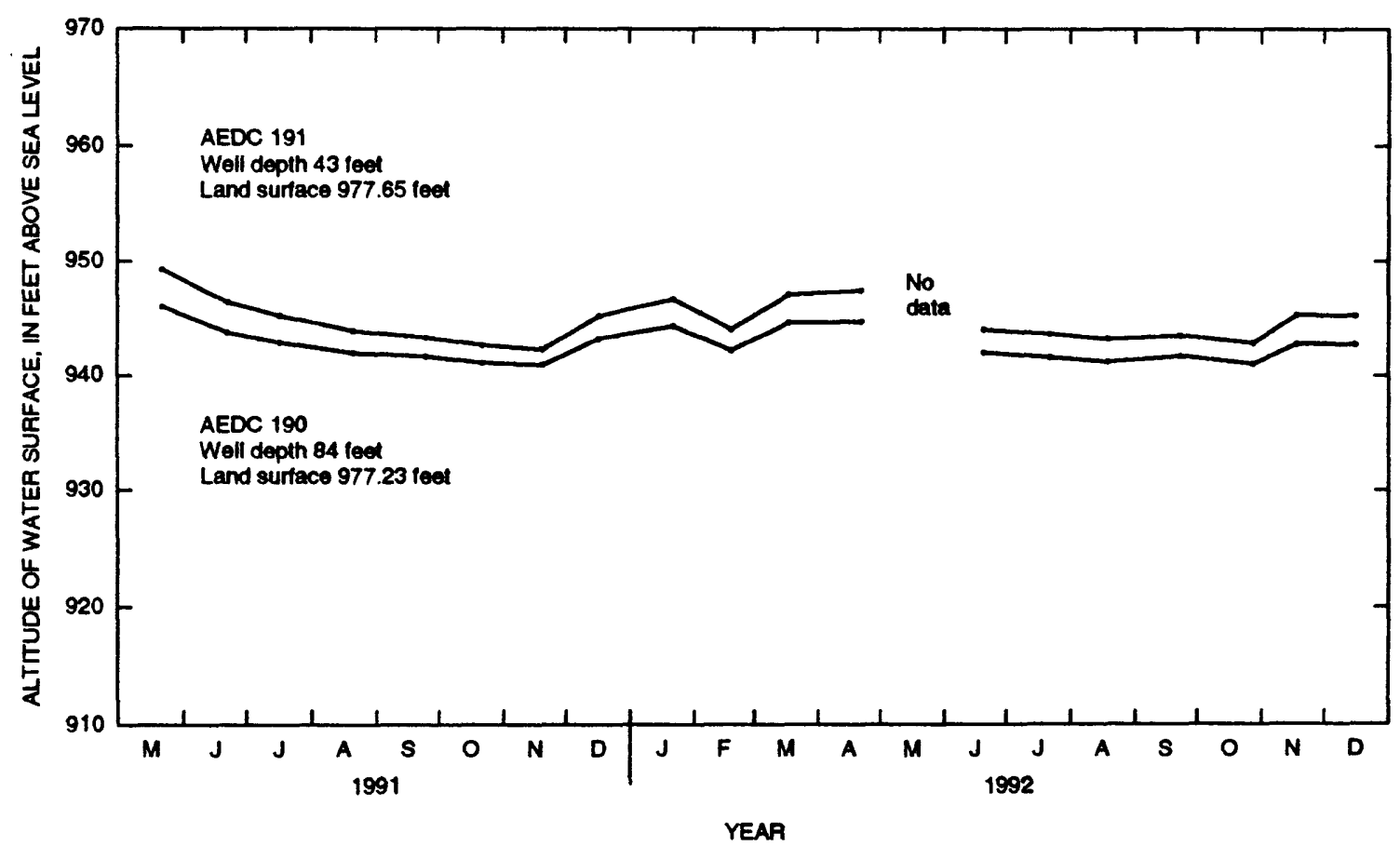

Figure 18. Water levels in wells AEDC 190 and 191 from May 1991 through December 1992.

24 Hydrogeology and Simulation of Ground-Water Flow at

Arnold Air Force Base, Coffee and Franklin Counties. Tennessee 


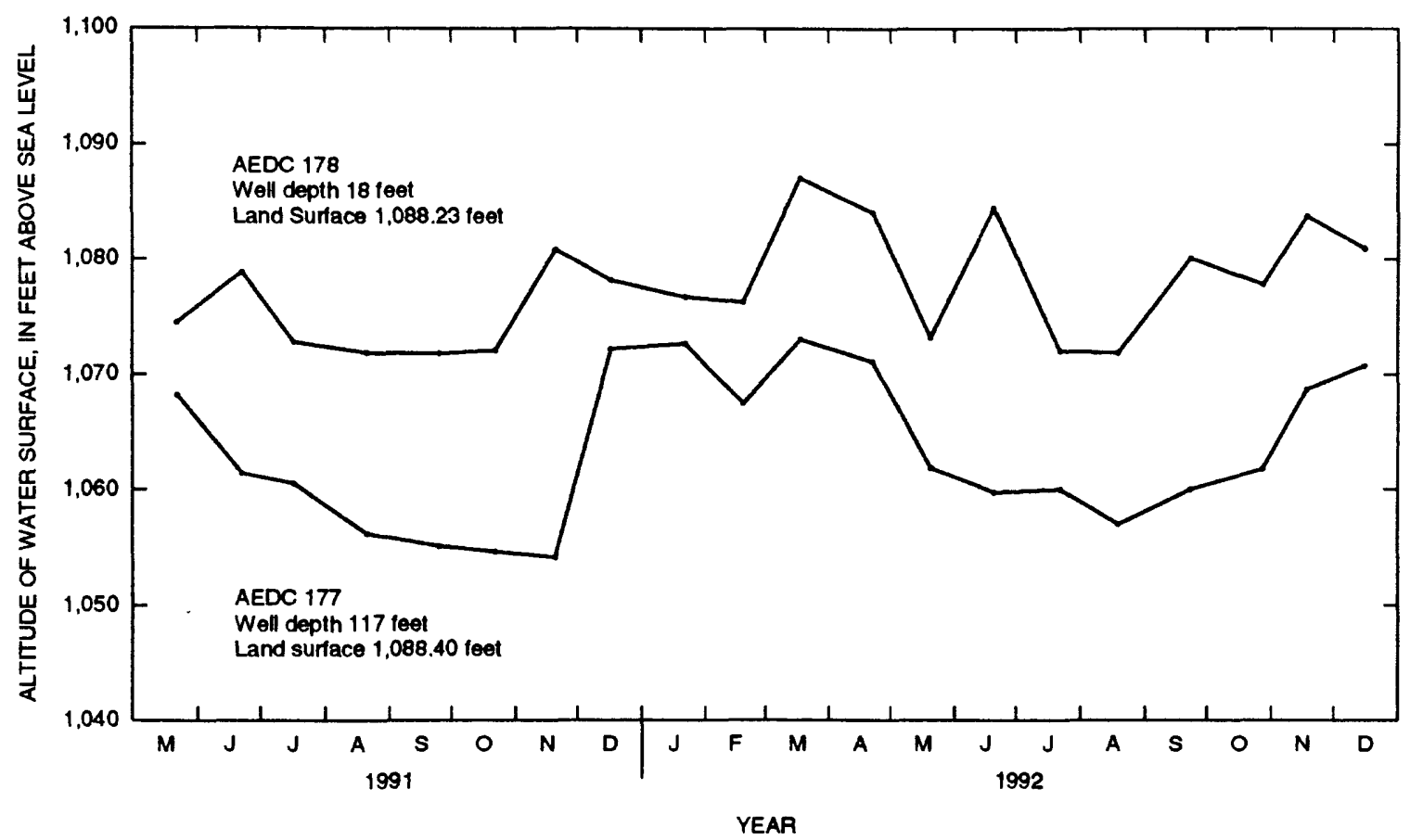

Figure 19. Water levels in wells AEDC 177 and 178 from May 1991 through December 1992.

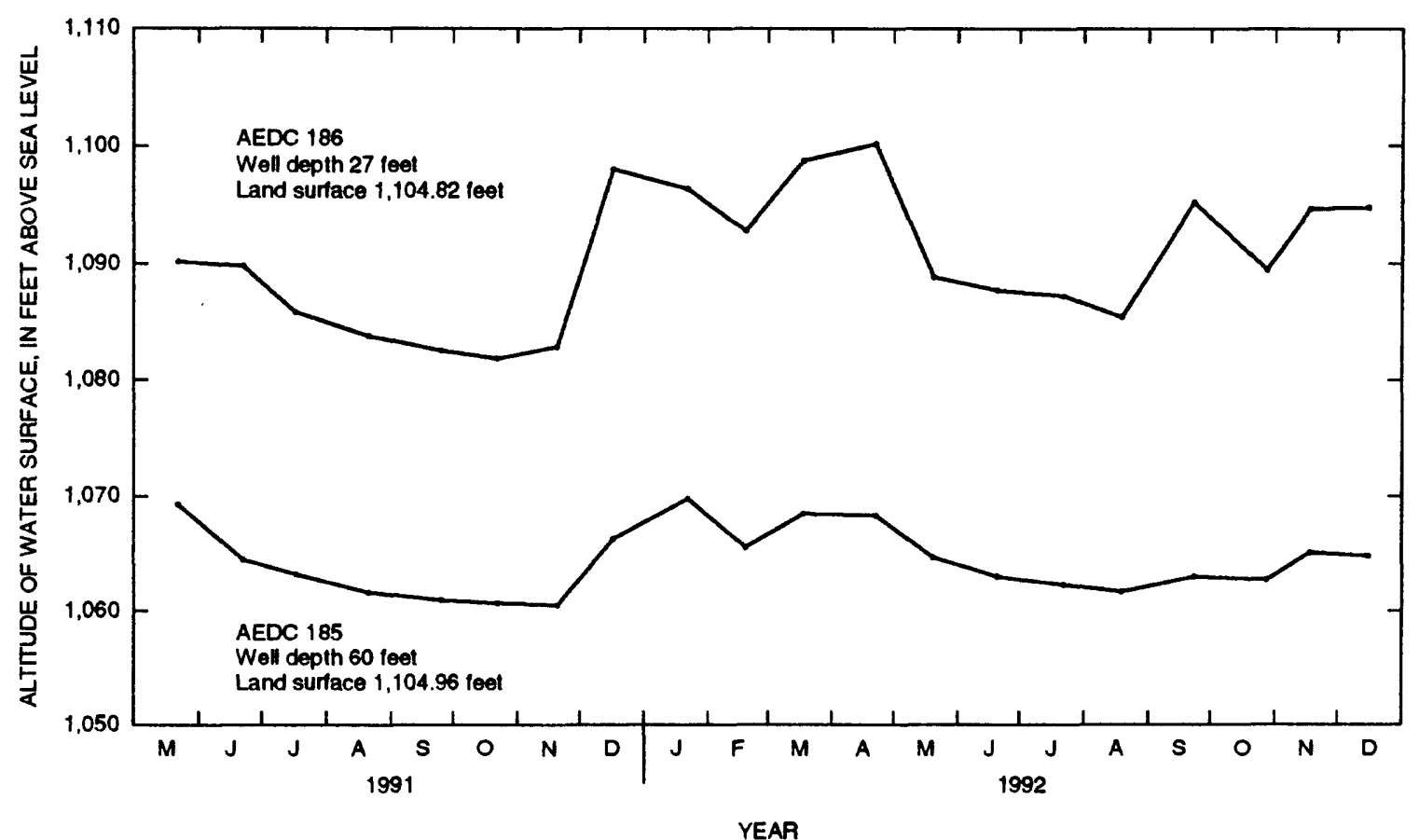

Figure 20. Water levels in wells AEDC 185 and 186 from May 1991 through December 1992. 


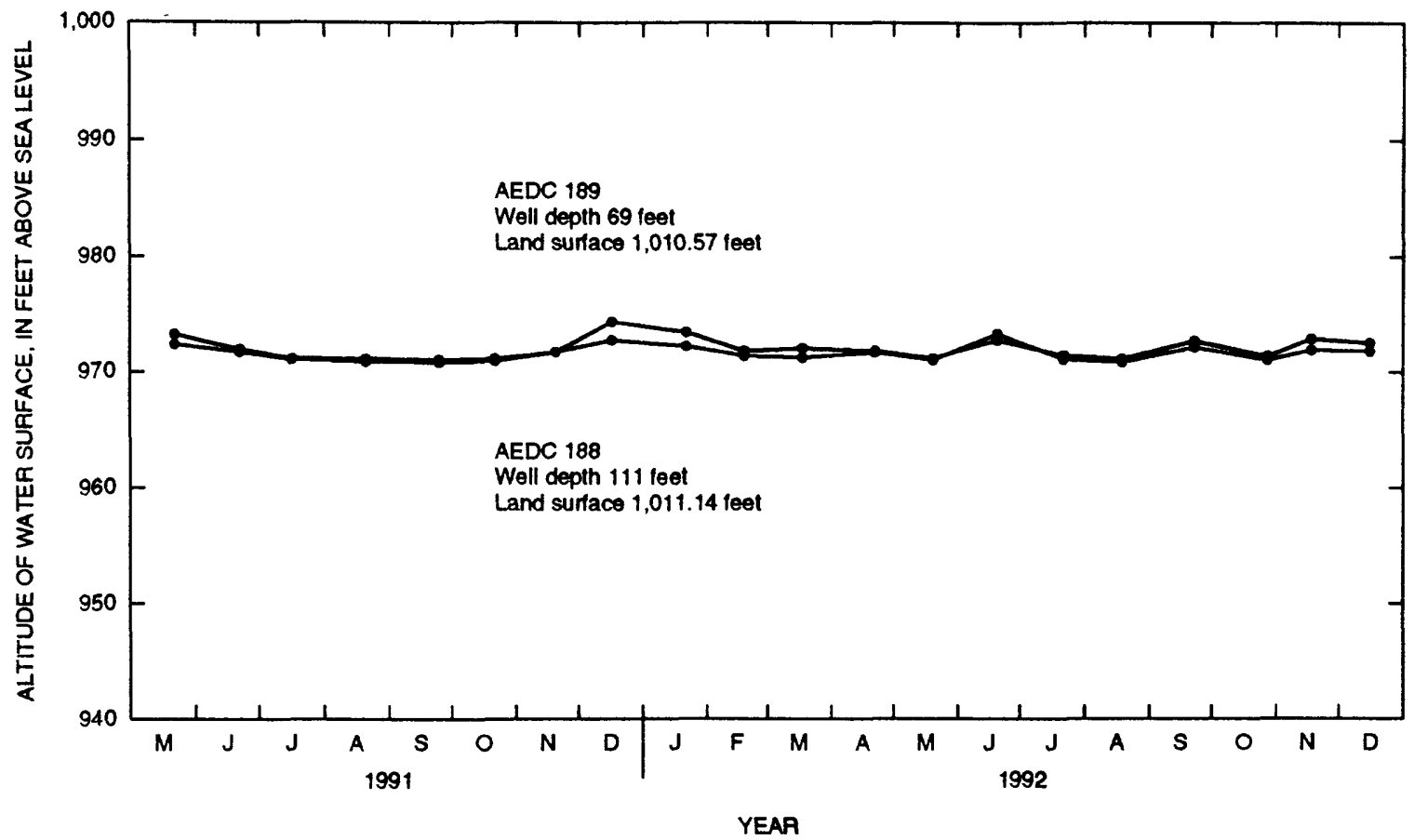

Figure 21. Water levels in wells AEDC 188 and 189 from May 1991 through December 1992.

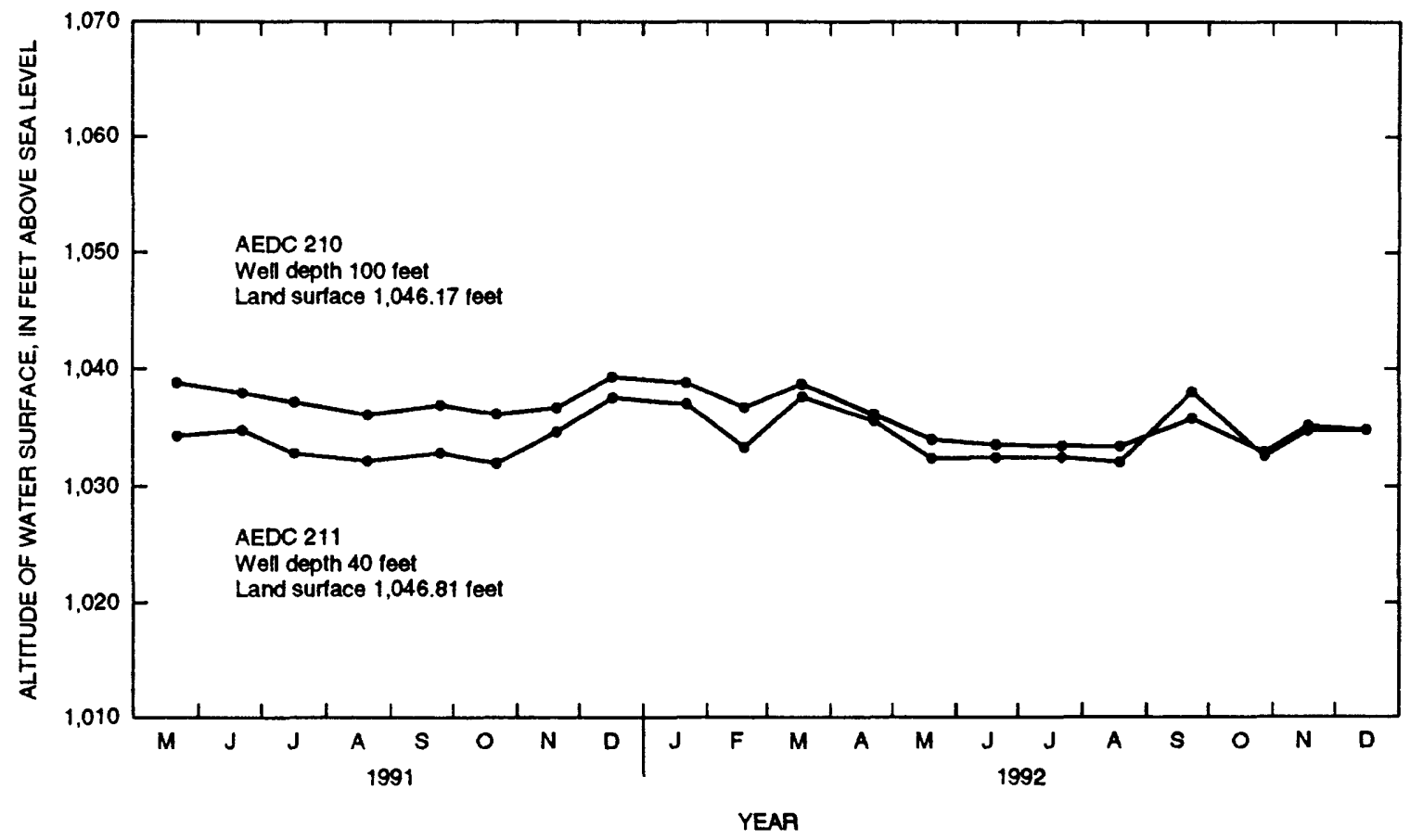

Figure 22. Water levels in wells AEDC 210 and 211 from May 1991 and December 1992.

26 Hydrogeology and Simulation of Ground-Water Flow at Arnold Air Force Base, Coffee and Franklin Counties, Tennessee 


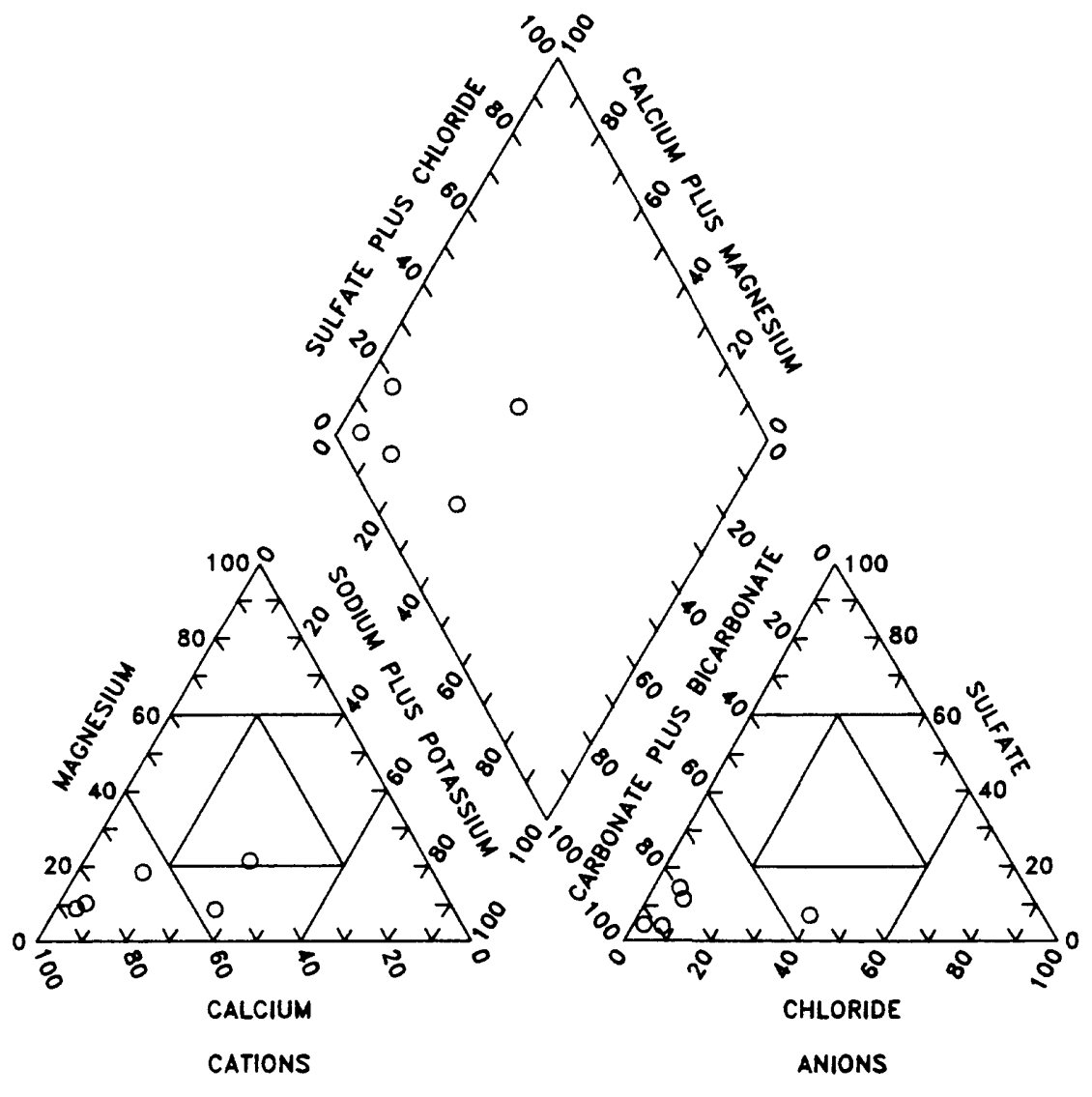

PERCENTAGE OF TOTAL MILLIEQUIVALENTS PER LITER

Figure 23. Chemical composition of water from wells completed in the shallow aquifer at Arnold Air Force Base.

less permeable part of the Fort Payne Formation. There is a shift towards sulfate as the principal anion. Pyrite, gypsum, and anhydrite provide the source for sulfate.

In water from the upper Central Basin aquifer, high dissolved-solids concentrations and high dissolved-chloride concentrations indicate a very slow flow system. The chloride-rich waters found here are typically associated with relatively older water with long travel times. The most likely sources of chloride and lithium are evaporites.

The differences in water chemistry between the aquifers are consistent with the conclusion by Chebotarev (1955) that as ground water evolves chemically, the following changes in the dominant anion species can be observed:

$\mathrm{HCO}_{3}^{-} \rightarrow \mathrm{HCO}_{3}^{-}+\mathrm{SO}_{4}^{-2} \rightarrow \mathrm{SO}_{4}^{-2}+\mathrm{HCO}_{3}^{-} \rightarrow \mathrm{SO}_{4}^{-2}$ $+\mathrm{Cl}^{-} \rightarrow \mathrm{Cl}^{-}+\mathrm{SO}_{4}^{-2} \rightarrow \mathrm{Cl}^{-} /$Increasing age

This sequence occurs as ground water moves through shallow zones of rapid flow to deeper zones with slower flow. The water-quality characteristics for each aquifer at AAFB are summarized in table 2.

\section{Organic constituents}

Samples were collected from 60 wells for analysis of volatile organic compounds. Most of the 


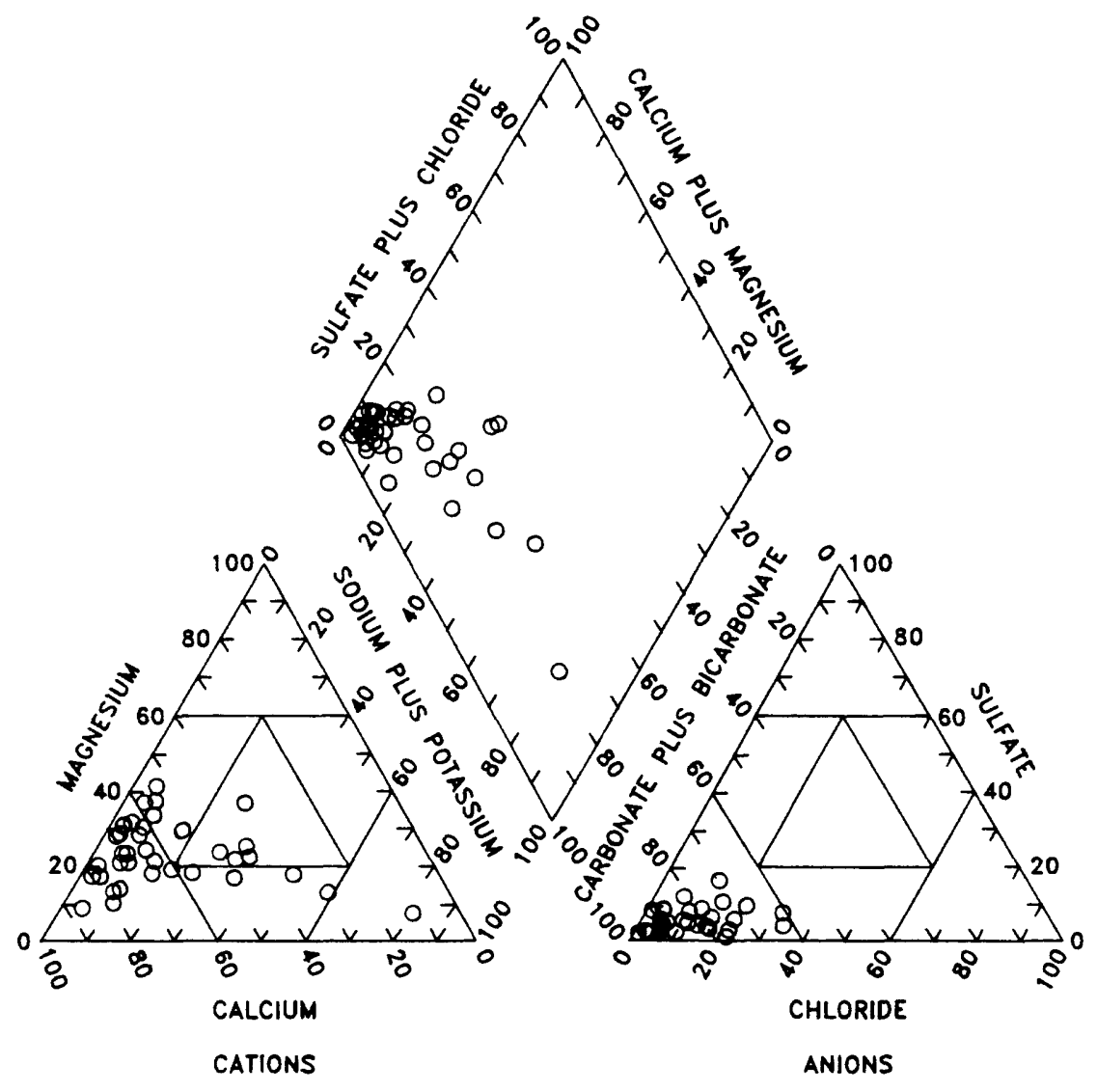

PERCENTAGE OF TOTAL MILLIEQUIVALENTS PER LITER

Figure 24. Chemical composition of water from wells completed in the Manchester aquifer at Arnold Air Force Base.

volatile organic compounds analyzed had concentrations below the detection limits. Approximately one-half of the wells sampled showed the presence of aromatic hydrocarbons such as benzene, toluene, ethylbenzene, and xylene (BTEX). The median, maximum, and minimum values for these compounds for wells sampled in each aquifer are shown in table 3. The highest concentrations of BTEX occurred in water from below the Chattanooga Shale in the upper Central Basin aquifer (table 3). These compounds occur naturally in association with petroleum deposits (natural gas and crude oil) and shale lithologies as well as in many refined petroleum products (Hunt, 1979; Slaine and Barker, 1990). When BTEX is detected in ground water, it is often difficult to distinguish between naturally occurring BTEX and contamination by refined petroleum products resulting from spills and landfill leachate (Barker and others, 1988).

Three wells, AEDC-190, -199, and -216, contained water with chlorinated organic compounds such as tetrachloroethylene, 1,1,1-trichloroethane, 1,1-dichloroethane, and 1,1-dichloroethylene at concentrations of $1.1 \mu \mathrm{g} / \mathrm{L}$ or less. Wells AEDC-199 and -216 are screened in the Manchester aquifer. Well AEDC-190 is screened in the Fort Payne aquifer. Water from well AEDC-190 also contained $15 \mu \mathrm{g} / \mathrm{L}$ trichlorofluoromethane (fig. 2). These compounds do not occur naturally in the environment and are an indication of man-made contamination. 


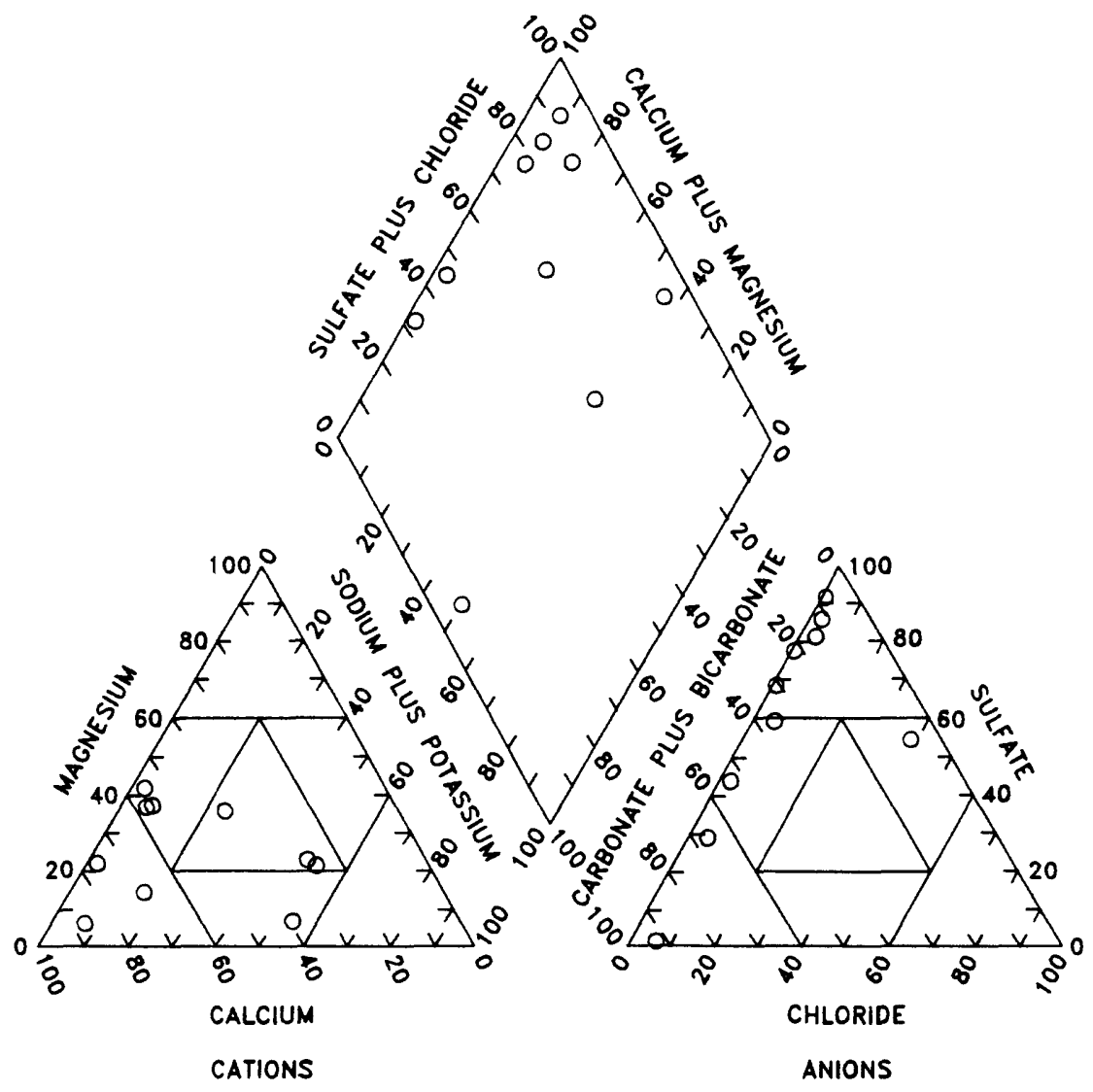

PERCENTAGE OF TOTAL MILLIEQUIVALENTS PER LITER

Figure 25. Chemical compostion of water from wells completed in the Fort Payne aquifer at Arnold Air Force Base.

\section{Surface Water}

The Elk River-Duck River drainage divide bisects the study area. The divide extends from the western edge of the study area eastward to the AEDC testing facilities and then turns northeasterly to the northeastern corner of the study area (fig. 9). Surface-water drainage patterns are well defined south and west of AEDC. Surface-water drainage patterns are less well defined in the wetland areas north and northeast of AEDC where many swamps and internally drained depressions exist.

The natural headwaters of several streams have been ditched and extended into AEDC to receive discharge water from the testing facilities. Most of the AEDC facility water is discharged to Rowland Creek, which has been ditched to extend across the natural drainage divide into AEDC. A retention reservoir at AEDC, constructed in the headwaters of a tributary to Crumpton Creek, also drains through engineered gates across the natural divide to Rowland Creek. The headwaters of Brumalow Creek and a tributary to Bradley Creek also have been extended into AEDC and receive small amounts of AEDC discharge water.

Surface drainage from the wetland areas north of AEDC drain to the southwest to Crumpton Creek and to the north to tributaries of the Little Duck River. Stream channels in this area are poorly defined and dry throughout most of the summer and fall. Some of the wetlands in this area, most 


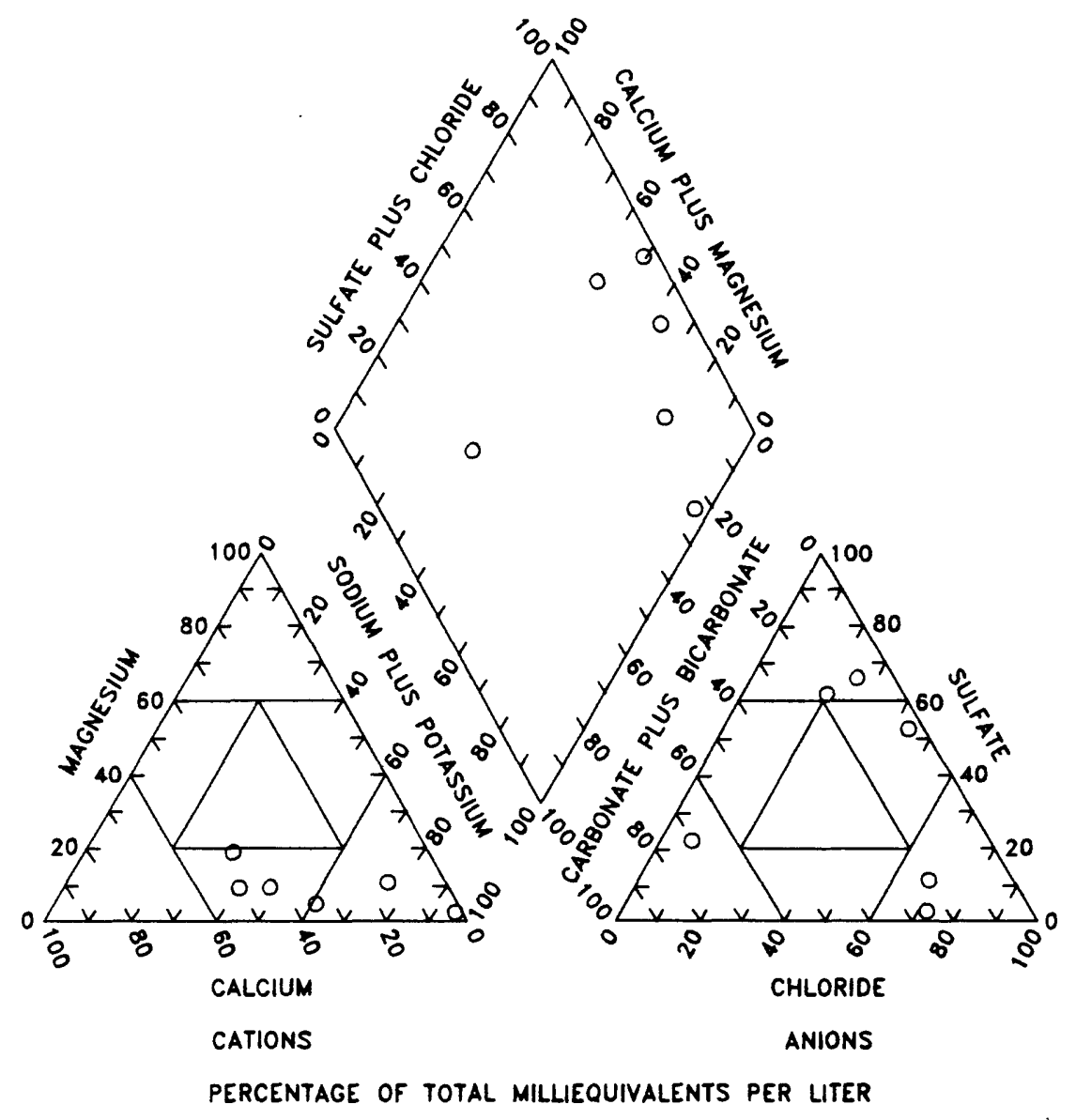

Figure 26. Chemical composition of water from wells completed in the upper Central Basin aquifer at Arnold Air Force Base.

notably Sinking Pond, are internally drained depressions. They are typically filled with water during the wet parts of the year and become dry during late summer and fall. Some of them have surface flow outlets.

The southwestern part of AAFB is drained by Spring Creek. The lower reaches of Spring Creek are well incised into chert gravels and support a sustained base flow.

\section{Stream Base Flow}

Base flow is that part of stream discharge derived from ground-water discharge to the stream. Base flow supports stream discharge during the periods between rainfall events. Most base flow to streams in the study area is probably from the regolith and shallow bedrock (the shallow and Manchester aquifers).

Twenty-nine surface-water stations were selected for base-flow discharge measurements (fig. 31). When the discharge measurements were made on November 2, 1990, 9 of the 29 sites had no flow. The discharge measurements for all sites are listed in table 4.

Streamflow records for the Duck River downstream from Manchester have been analyzed by Hoos (1990) to determine net annual recharge in inches per year. About half of the drainage area for this station lies in the northern part of the study area. Because more than 50 years of streamflow 


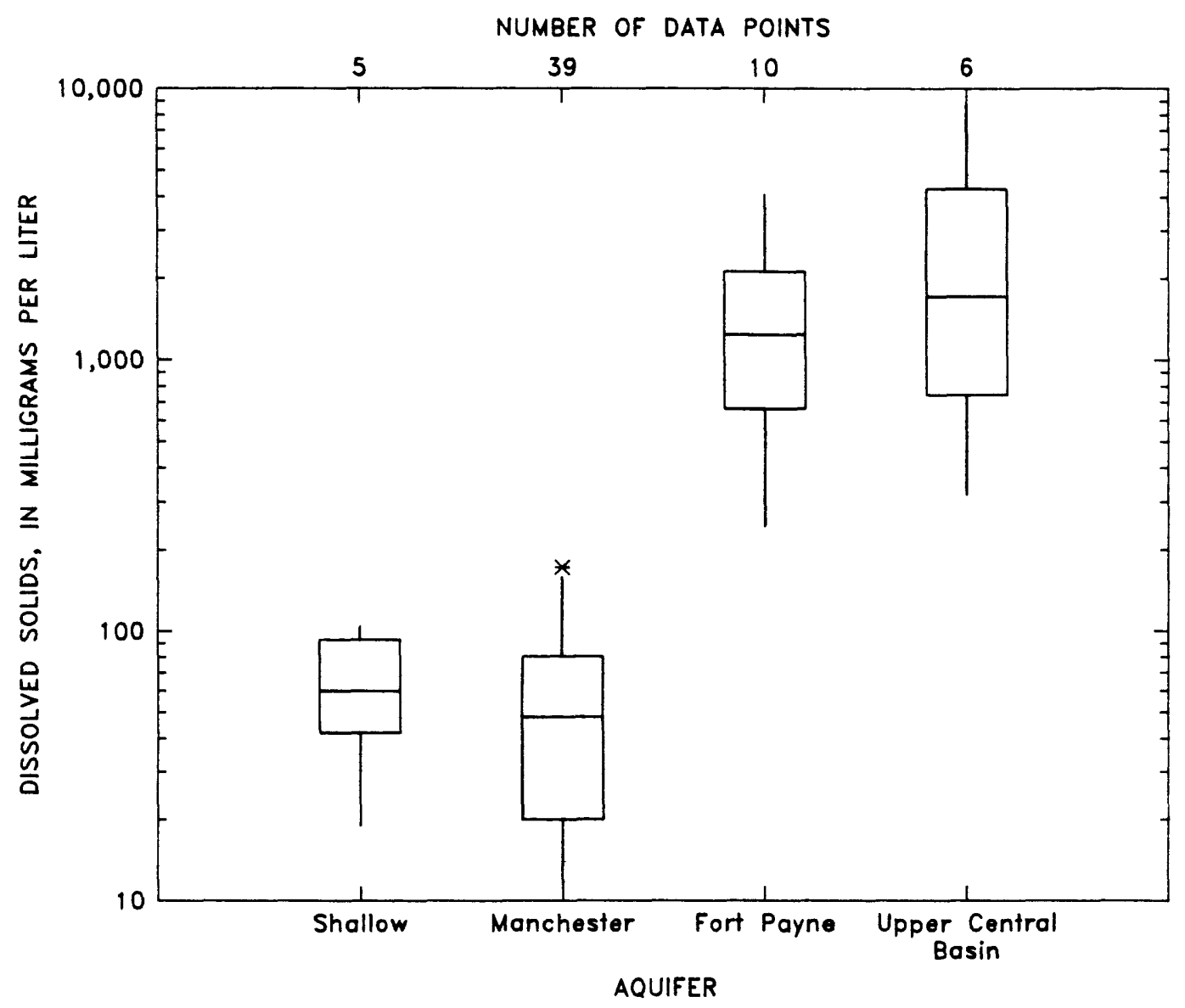

EXPLANATION

* - EXTREME VALUE

(Greater than

$1.5 \times$ IQR above

top of box)

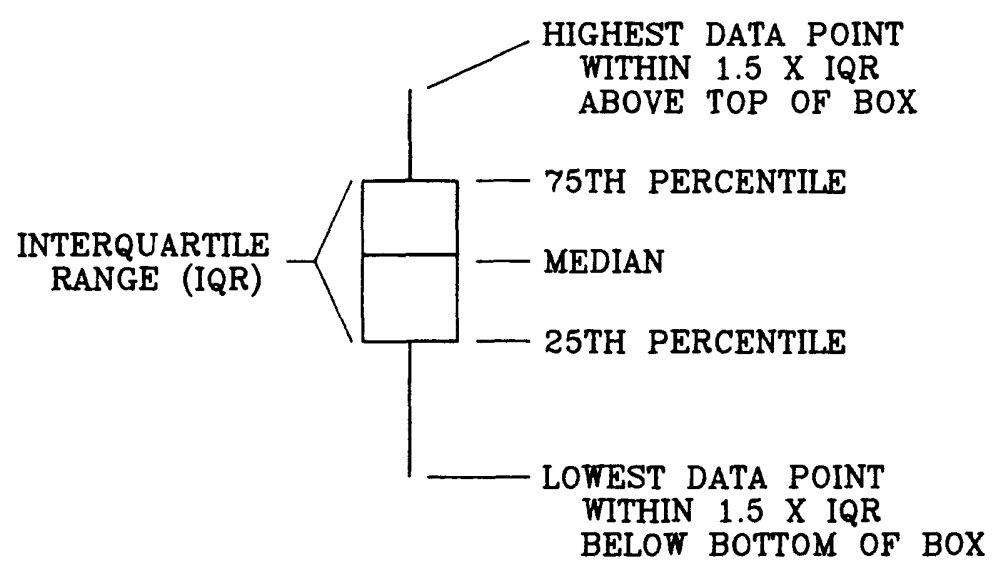

Figure 27. Ranges of dissolved solids concentration in ground water at Arnold Air Force Base. 


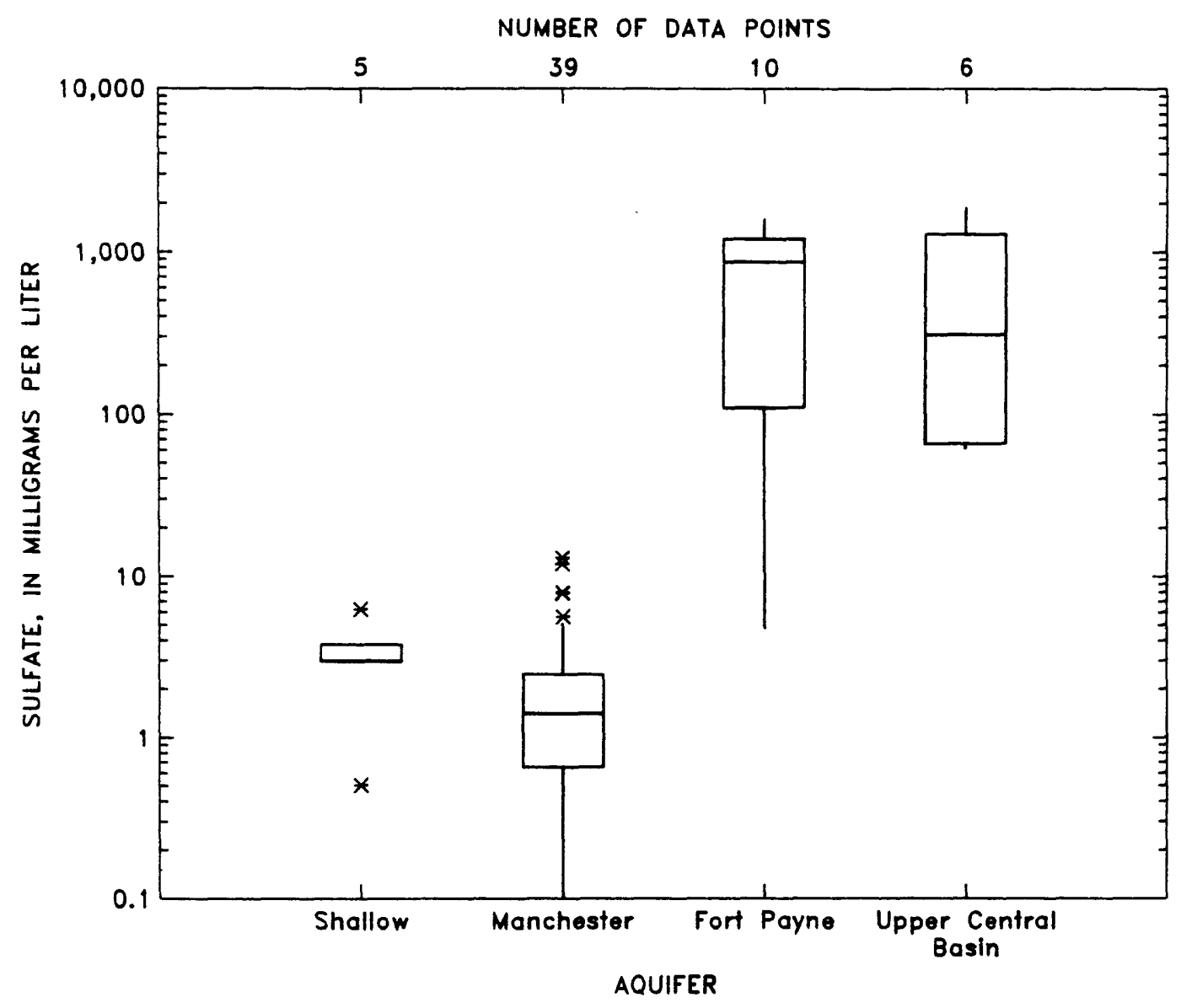

EXPLANATION

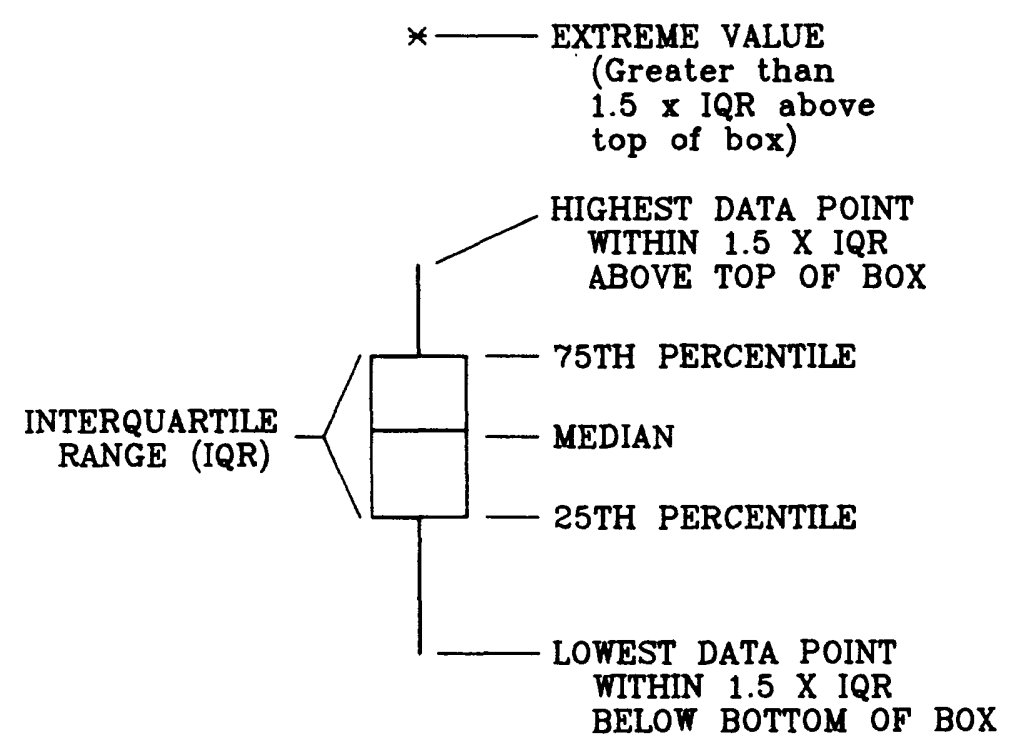

Figure 28. Ranges of sulfate concentration in ground water at Arnold Air Force Base.

32 Hydrogeology and Simulation of Ground-Water Flow at

Arnold Air Force Base. Coffee and Franklin Counties, Tennesses 


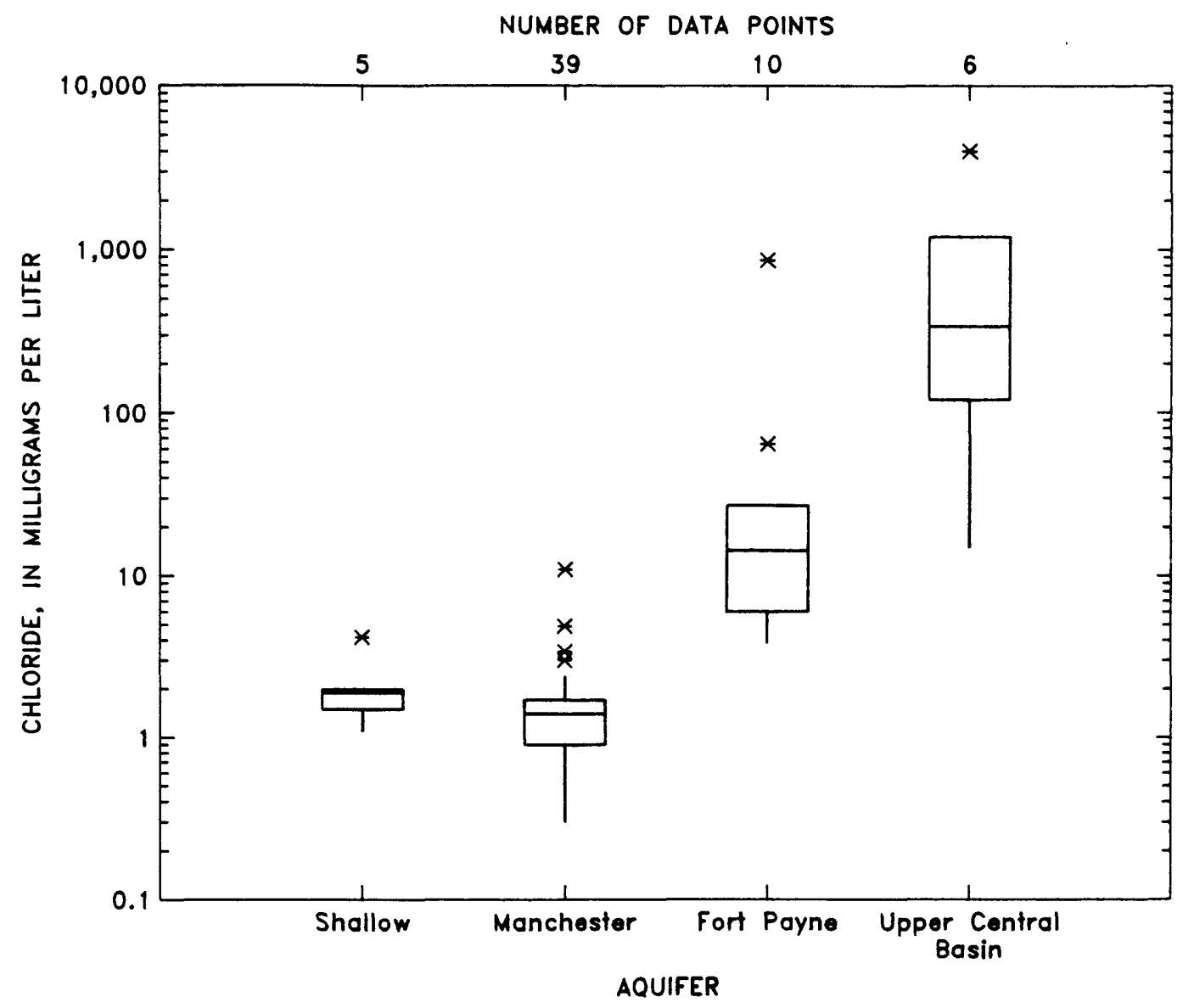

EXPLANATION

* - EXTREME VALUE

(Greater than

$1.5 \times$ IQR above

top of box)

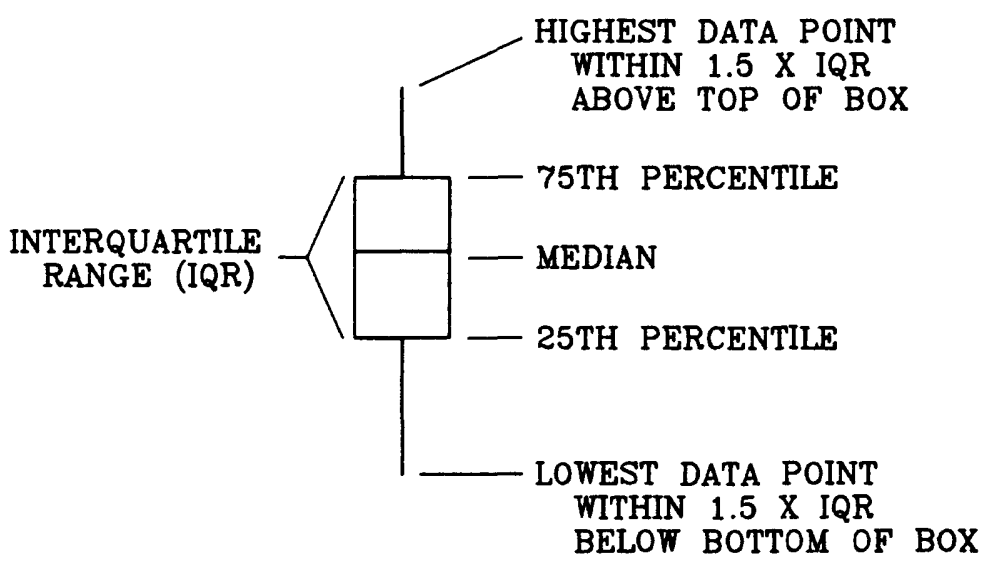

Figure 29. Ranges of chloride concentration in ground water at Arnold Air Force Base. 


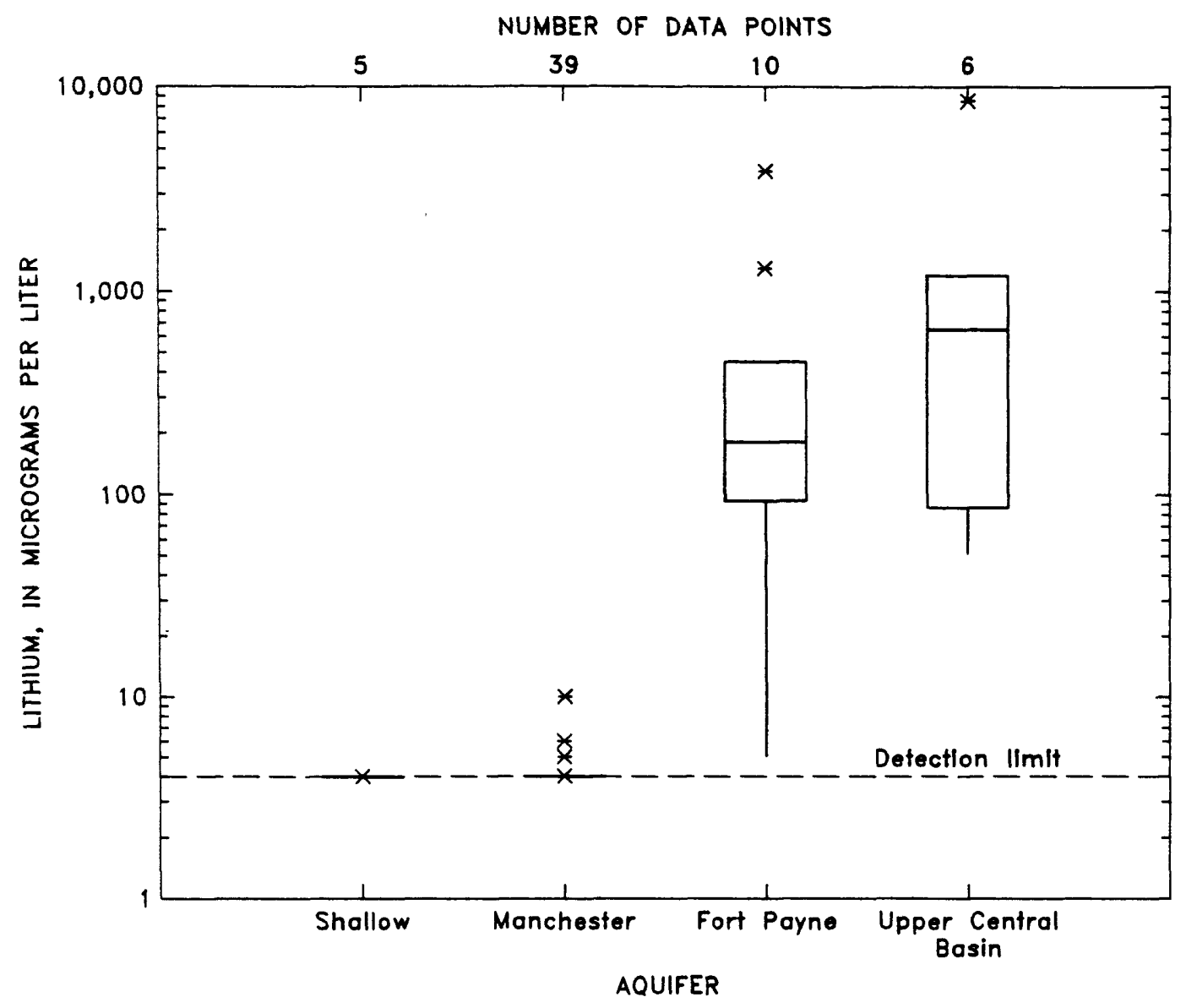

EXPLANATION

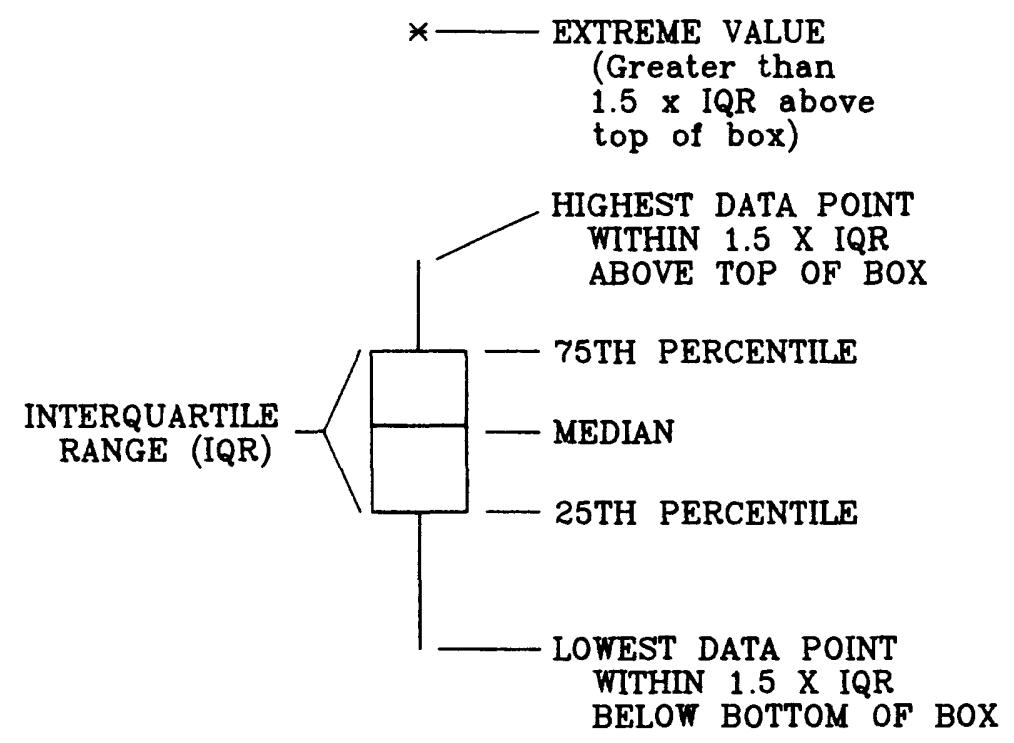

Figure 30. Ranges of lithium concentration in ground water at Arnold Air Force Base.

34 Hydrogeology and Simulation of Ground-Water Flow at

Arnold Air Force Base, Coffee and Franklin Counties, Tennessee 


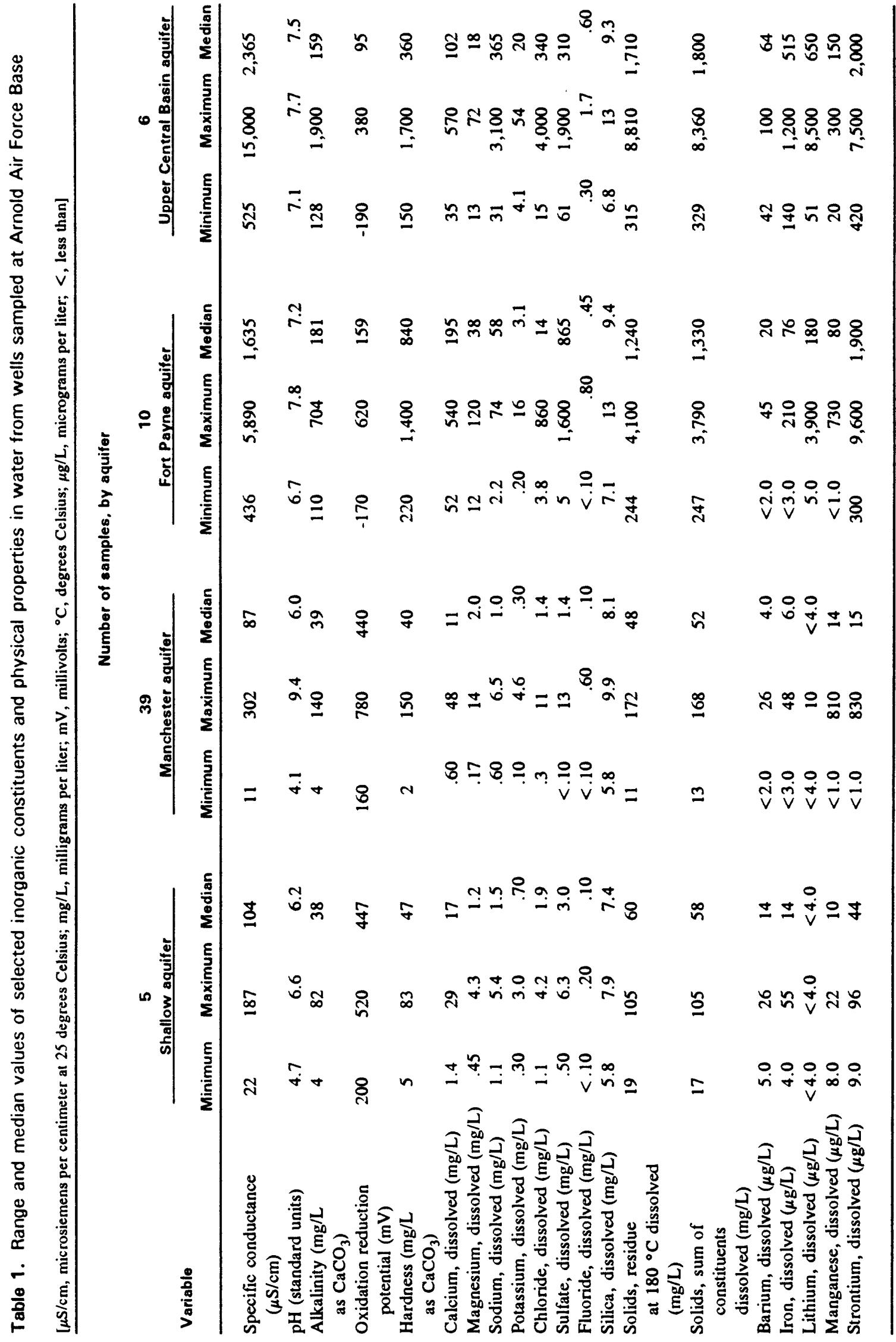


Table 2. Summary of water-quality and hydrogeologic characteristics for the aquifers at Arnold Air Force Base

\begin{tabular}{|c|c|c|c|}
\hline Aquifer & $\begin{array}{c}\text { Chemical } \\
\text { classification }\end{array}$ & $\begin{array}{c}\text { Dissolved } \\
\text { solids } \\
\text { (milligrams per liter) }\end{array}$ & Comments \\
\hline Shallow & $\mathrm{Ca}-\mathrm{HCO}_{3}$ & $20-100$ & $\begin{array}{l}\text { Low producing wells, shallow ground-water circulation, low } \\
\text { dissolved solids, and bicarbonate dominant anion. }\end{array}$ \\
\hline Manchester & $\mathrm{Ca}-\mathrm{HCO}_{3}$ & $10-175$ & $\begin{array}{l}\text { Good producing wells, rapid ground-water circulation, low } \\
\text { dissolved solids, and bicarbonate dominant anion. }\end{array}$ \\
\hline Fort Payne & $\mathrm{Ca}-\mathrm{HCO}_{3}, \mathrm{SO}_{4}$ & $250-4,000$ & $\begin{array}{l}\text { Low well yields, slow ground-water circulation, higher } \\
\text { dissolved solids, and high sulfate. }\end{array}$ \\
\hline $\begin{array}{l}\text { Upper Central } \\
\text { Basin. }\end{array}$ & $\mathrm{Na}-\mathrm{SO}_{4}, \mathrm{Cl}$ & $300-9,000$ & $\begin{array}{l}\text { Very slow ground-water circulation, high dissolved solids, } \\
\text { high chlorides, and high lithium. }\end{array}$ \\
\hline
\end{tabular}

Table 3. Summary by aquifer of concentrations of benzene, toluene, ethylbenzene, and xylene compounds in water from wells sampled at Arnold Air Force Base

[ $\mu \mathrm{g} / \mathrm{L}$, micrograms per liter; <, less than]

Number of samples, by aquifer

\begin{tabular}{|c|c|c|c|c|c|}
\hline \multirow[b]{2}{*}{$\begin{array}{l}\text { Con- } \\
\text { stit- } \\
\text { uent }\end{array}$} & & \\
\hline & & $\begin{array}{c}\text { Shallow } \\
\text { aquifer }\end{array}$ & $\begin{array}{c}\text { Manchester } \\
\text { aquifer }\end{array}$ & $\begin{array}{c}10 \\
\text { Fort } \\
\text { Payne } \\
\text { aquifer }\end{array}$ & $\begin{array}{c}6 \\
\text { Upper } \\
\text { Central } \\
\text { Basin } \\
\text { aquifer }\end{array}$ \\
\hline \multirow{3}{*}{$\begin{array}{l}\text { Benzene } \\
\qquad(\mu \mathrm{g} / \mathrm{L})\end{array}$} & Median & $<0.2$ & $<0.2$ & 2.0 & 700 \\
\hline & Maximum & .5 & 12 & 1,400 & 6,200 \\
\hline & Minimum & $<.2$ & $<.2$ & $<.2$ & $<.2$ \\
\hline \multirow{3}{*}{$\begin{array}{l}\text { Toluene } \\
\qquad(\mu \mathrm{g} / \mathrm{L})\end{array}$} & Median & $<.2$ & .4 & 2.8 & 210 \\
\hline & Maximum & 1.1 & 7.6 & 800 & 3,500 \\
\hline & Minimum & $<.2$ & $<.2$ & .2 & $<.2$ \\
\hline \multirow{3}{*}{$\begin{array}{l}\text { Ethyl- } \\
\text { benzene } \\
(\mu \mathrm{g} / \mathrm{L})\end{array}$} & Median & $<.2$ & $<.2$ & .6 & 5.6 \\
\hline & Maximum & .2 & .6 & 94 & 180 \\
\hline & Minimum & $<.2$ & $<.2$ & $<.2$ & $<.2$ \\
\hline \multirow{3}{*}{$\begin{array}{l}\text { Xylene } \\
\qquad(\mu \mathrm{g} / \mathrm{L})\end{array}$} & Median & $<.2$ & $<.2$ & 2.4 & 27 \\
\hline & Maximum & .7 & 1.7 & 360 & 920 \\
\hline & Minimum & $<.2$ & $<.2$ & $<.2$ & $<.2$ \\
\hline
\end{tabular}

36 Hydrogeology and Simulation of Ground-Water Flow at Arnold Air Force Base, Coffee and Franklin Counties, Tennessee 

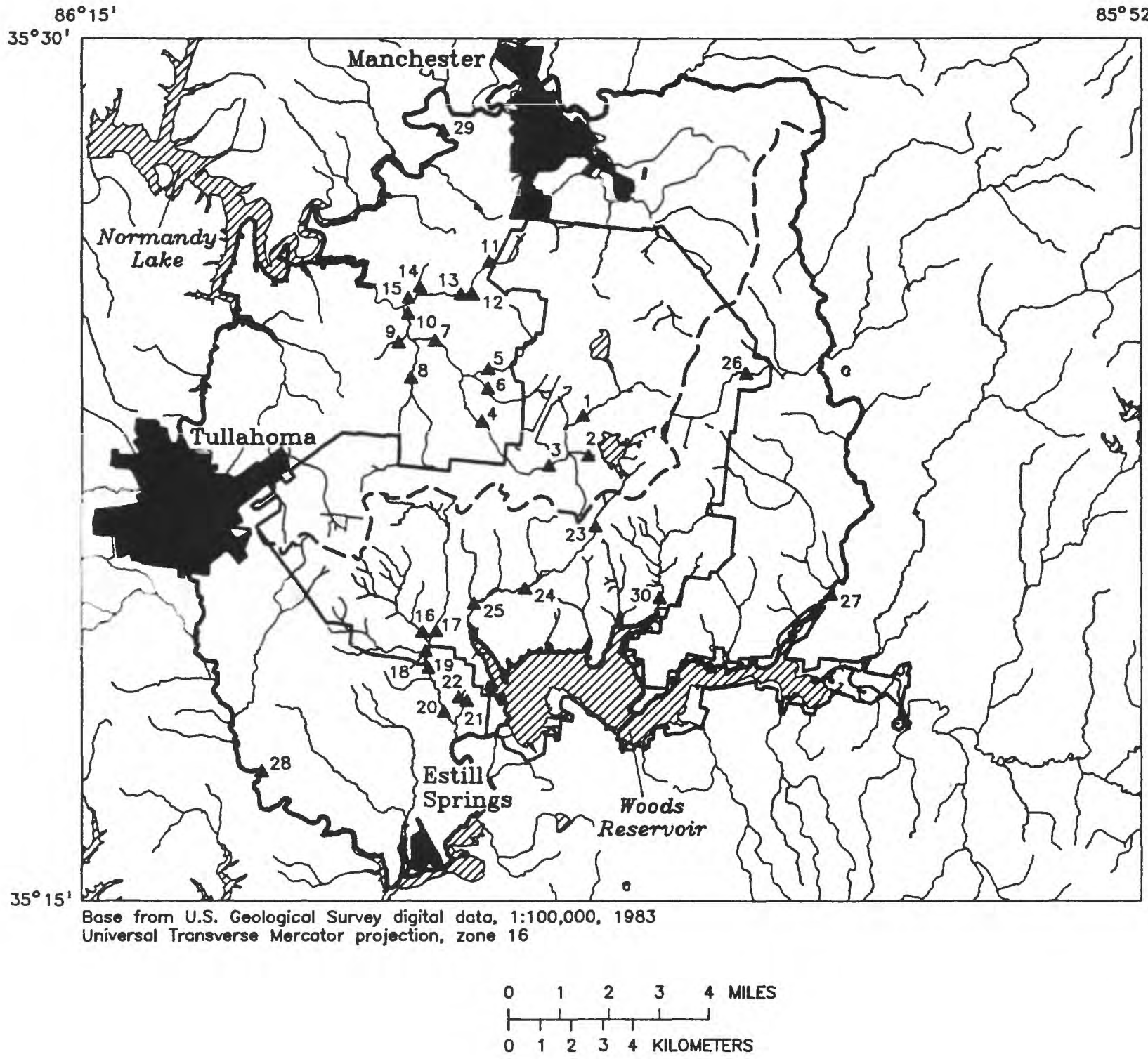

\section{EXPLANATION}
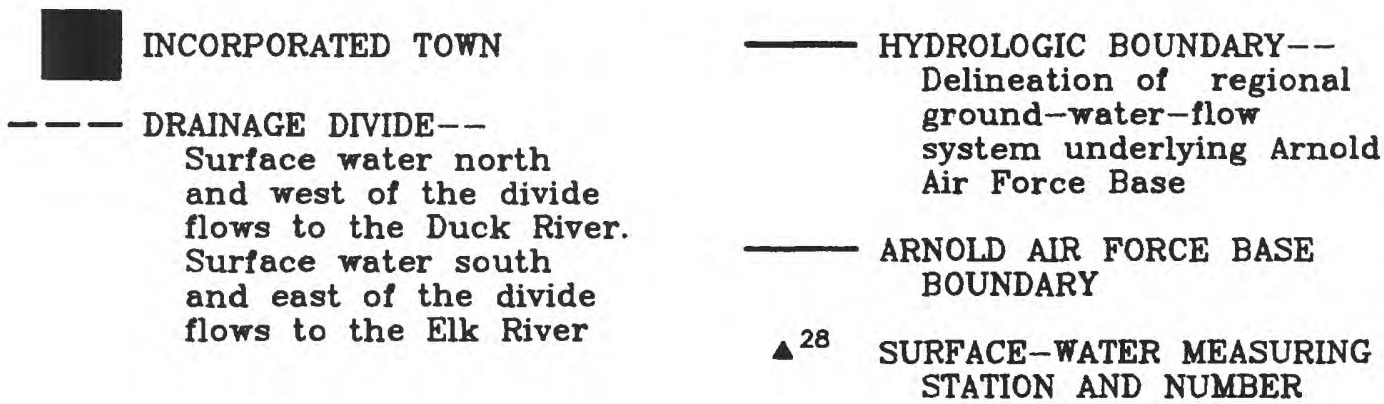

Figure 31. Location of the surface-water measuring stations in the Arnold Air Force Base area. 
Table 4. Stream discharge measurements made on November 2, 1990 at stations in the Arnold Air Force Base area

[ $\mathrm{ft}^{3} / \mathrm{s}$, cubic foot per second; $\mathrm{mi}^{2}$, square miles; NA, not applicable; - , no data]

\begin{tabular}{|c|c|c|c|c|}
\hline Stream station & $\begin{array}{l}\text { Map number } \\
\text { (on fig. 31) }\end{array}$ & $\begin{array}{l}\text { Discharge } \\
\left(\mathrm{ft}^{3} / \mathrm{s}\right)\end{array}$ & $\begin{array}{c}\text { Drainage area } \\
\left(\mathrm{mi}^{2} \mid\right.\end{array}$ & $\begin{array}{c}\text { Discharge per } \\
\text { unit drainage ares } \\
\left(\mathrm{ft}^{3} / \mathrm{s} / \mathrm{mi}^{2}\right)\end{array}$ \\
\hline $\begin{array}{l}\text { Crumpton Creek at } \\
\text { Chapel Hill Cemetery. }\end{array}$ & 1 & 0.0 & 3.93 & 0.0 \\
\hline $\begin{array}{l}\text { Unnamed tributary to Crumpton } \\
\text { Creek below AEDC. }\end{array}$ & 2 & .03 & 1.05 & .029 \\
\hline $\begin{array}{l}\text { Crumpton Creek near } \\
\text { Arnold airfield. }\end{array}$ & 3 & .0 & 7.45 & .0 \\
\hline $\begin{array}{l}\text { Crumpton Creek at Old Hillsboro } \\
\text { Road near Hickerson Station. }\end{array}$ & 4 & 1.12 & 9.99 & .11 \\
\hline $\begin{array}{l}\text { Unnamed tributary to Crumpton } \\
\text { Creek tributary at Belmont Road. }\end{array}$ & 5 & .0 & 1.78 & .0 \\
\hline $\begin{array}{l}\text { Crumpton Creek tributary } \\
\text { at Belmont Road. }\end{array}$ & 6 & .0 & 1.43 & .0 \\
\hline $\begin{array}{l}\text { Crumpton Creek at Old Manchester } \\
\text { Highway near Hickerson Station. }\end{array}$ & 7 & .74 & 15.59 & .047 \\
\hline $\begin{array}{l}\text { Hickerson Spring Branch near } \\
\text { Hickerson Station. }\end{array}$ & 8 & .58 & 4.52 & .13 \\
\hline $\begin{array}{l}\text { Crumpton Creek tributary at } \\
\text { Rutledge Falls. }\end{array}$ & 9 & .41 & 1.08 & .38 \\
\hline $\begin{array}{l}\text { Crumpton Creek above Wiley Creek } \\
\text { at Rutledge Falls. }\end{array}$ & 10 & 3.4 & 22.21 & .15 \\
\hline $\begin{array}{l}\text { Wiley Creek at Old Manchester } \\
\text { Highway at Black Jack. }\end{array}$ & 11 & .0 & 1.70 & .0 \\
\hline Wiley Spring at Belmont & 12 & .54 & NA & NA \\
\hline $\begin{array}{l}\text { Wiley Creek below Wiley Springs } \\
\text { at Belmont. }\end{array}$ & 13 & .91 & 2.86 & .32 \\
\hline $\begin{array}{l}\text { Wiley Creek tributary below } \\
\text { Rutledge Falls Road. }\end{array}$ & 14 & .0 & .59 & .0 \\
\hline Wiley Creek at Rutledge Falls & 15 & 1.8 & 4.44 & .41 \\
\hline Spring Creek in Saltwell Hollow & 16 & .0 & 3.08 & .0 \\
\hline $\begin{array}{l}\text { Spring Creek tributary in } \\
\text { Saltwell Hollow. }\end{array}$ & 17 & .0 & 2.77 & .0 \\
\hline Spring Creek below Saltwell Hollow & 18 & .0 & 5.86 & .0 \\
\hline $\begin{array}{l}\text { Spring Creek below Spring Creek } \\
\text { Cemetery. }\end{array}$ & 19 & 5.3 & 7.90 & .67 \\
\hline Spring Creek off Spring Creek Road & 20 & 7.8 & 9.51 & .82 \\
\hline $\begin{array}{l}\text { Spring Creek tributary off Spring } \\
\text { Creek Road. }\end{array}$ & 21 & .10 & .24 & .42 \\
\hline $\begin{array}{l}\text { Spring Creek Spring off Spring } \\
\text { Creek Road. }\end{array}$ & 22 & .84 & NA & NA \\
\hline Rowland Creek at Arnold Center Road & 23 & 45.4 & .8731 & 52.0 \\
\hline Rowland Creek at UTSI Road & 24 & 46.8 & 3.18 & 14.7 \\
\hline Rowland Creek at end of roadway & 25 & 44.3 & 5.23 & 8.5 \\
\hline $\begin{array}{l}\text { Unnamed tributary to Bradley Creek } \\
\text { near Arnold Center Road. }\end{array}$ & 26 & 1.9 & 1.97 & .96 \\
\hline Bradley Creek near Calls & 27 & 16.8 & 43.05 & .39 \\
\hline Rock Creek at Hines Road & 28 & 12.8 & 33.6 & .38 \\
\hline Duck River below Manchester & 29 & 38 & 107 & .36 \\
\hline $\begin{array}{l}\text { Brumalow Creek at Old Brick } \\
\text { Church Road. }\end{array}$ & 30 & - & - & - \\
\hline
\end{tabular}

38 Hydrogeology and Simulation of Ground-Water Flow at Arnold Air Force Base, Coffee and Franklin Counties, Tennessee 
data are available for this station, the record provides baseline data to compare with other stations in the study area. Estimated net annual recharge was 4.0, 9.8, and 10.1 inches per year for low, average, and high flow years. Net annual recharge is assumed to equal base flow in the stream. Knowing that the drainage area of the Duck River downstream from Manchester is 107 square miles, the annual base flow at this station can be calculated. Low, average, and high base flows of 32,77 , and $80 \mathrm{ft}^{3} / \mathrm{s}$, respectively, result. Base flow varies by a factor of about 3 . On November 2, 1990, the discharge at the Duck River downstream from Manchester was $38 \mathrm{ft}^{3} / \mathrm{s}$ or near the low base-flow estimate. This suggests that the streamflow measurements made in the study area on November 2, 1990, were near low baseflow conditions.

By dividing the discharge measurement by the drainage area to obtain a base-flow discharge per square mile, unit base-flow between stations can be compared. Comparing the Duck River downstream from Manchester base flow $\left(0.36\left(\mathrm{ft}^{3} / \mathrm{s}\right) \mathrm{mi}^{2}\right)$ with the other stations in table 4 , the Spring Creek drainage has a higher base flow $\left(0.82\left(\mathrm{ft}^{3} / \mathrm{s}\right) / \mathrm{mi}^{2}\right)$ and the Crumpton Creek drainage has a lower base flow $\left(0.15\left(\mathrm{ft}^{3} / \mathrm{s}\right) \mathrm{mi}^{2}\right)$. The Bradley Creek $\left(0.39\left(\mathrm{ft}^{3} / \mathrm{s}\right) \mathrm{mi}^{2}\right)$, Rock Creek $\left(0.38\left(\mathrm{ft}^{3} / \mathrm{s}\right) / \mathrm{mi}^{2}\right)$, and Wiley Creek $\left(0.41\left(\mathrm{ft}^{3} / \mathrm{s}\right) / \mathrm{mi}^{2}\right)$ drainages all have similar unit base flow values. Comparisons cannot be made with the Rowland Creek drainage because most of its flow is derived from discharge water from AEDC.

The most likely explanation for the higher unit base flow for the Spring Creek drainage is that the thicker regolith in the area supplies more ground water to the stream. Furthermore, the streambed of Spring Creek is well defined and incised into chert gravels allowing good contact with the aquifer. In contrast, the upper reaches of Crumpton Creek have poorly defined, wide, shallow streambeds and are underlain by thinner regolith. The drainage area near the headwaters of Crumpton Creek is in a wetland area with several internally drained depressions.

\section{Water Quality}

In October 1991, water samples were collected at eight surface-water stations and analyzed for major and trace inorganic constituents (table 5). These samples represent the water quality during base-flow conditions. A trilinear diagram (fig. 32) shows that the water is of the calcium bicarbonate type similar to that found in the shallow and Manchester aquifers. Additionally, the reported values for almost every constituent fall within the range of values reported for the shallow and Manchester aquifers. This indicates that base flow in the streams is derived mainly from the shallow and Manchester aquifers with little contribution from the deeper zones. These values support the conclusions that most ground-water flow occurs in the shallow and Manchester aquifers with rapid circulation and a small percentage of the ground-water flow is supported by the Fort Payne aquifer with slow circulation.

The only extreme values in table 5 are dissolved iron and dissolved manganese concentrations of 11,000 and $1,900 \mu \mathrm{g} / \mathrm{L}$, respectively, at the unnamed tributary to Crumpton Creek below AEDC (fig. 31, station 2). Water at this station originates from seeps just below the earth dam at the AEDC retention reservoir. These values, in addition to a $\mathrm{pH}<7.0$, indicate a reducing environment in the reservoir bottom and the seepage from it. Reddish-brown stains on the sediments in the stream at this station indicate iron oxidation and subsequent precipitation of iron oxides and oxyhydroxides.

\section{SIMULATION OF GROUND-WATER FLOW}

The physical system, described in the hydrogeology section of this report, provides the framework for a ground-water-flow model. A model that simulates the flow of water through aquifers provides a useful tool to test the understanding and concepts of the flow system. Although a model is necessarily a simplification of the physical system, the model should be consistent with all known hydrogeologic observations. 


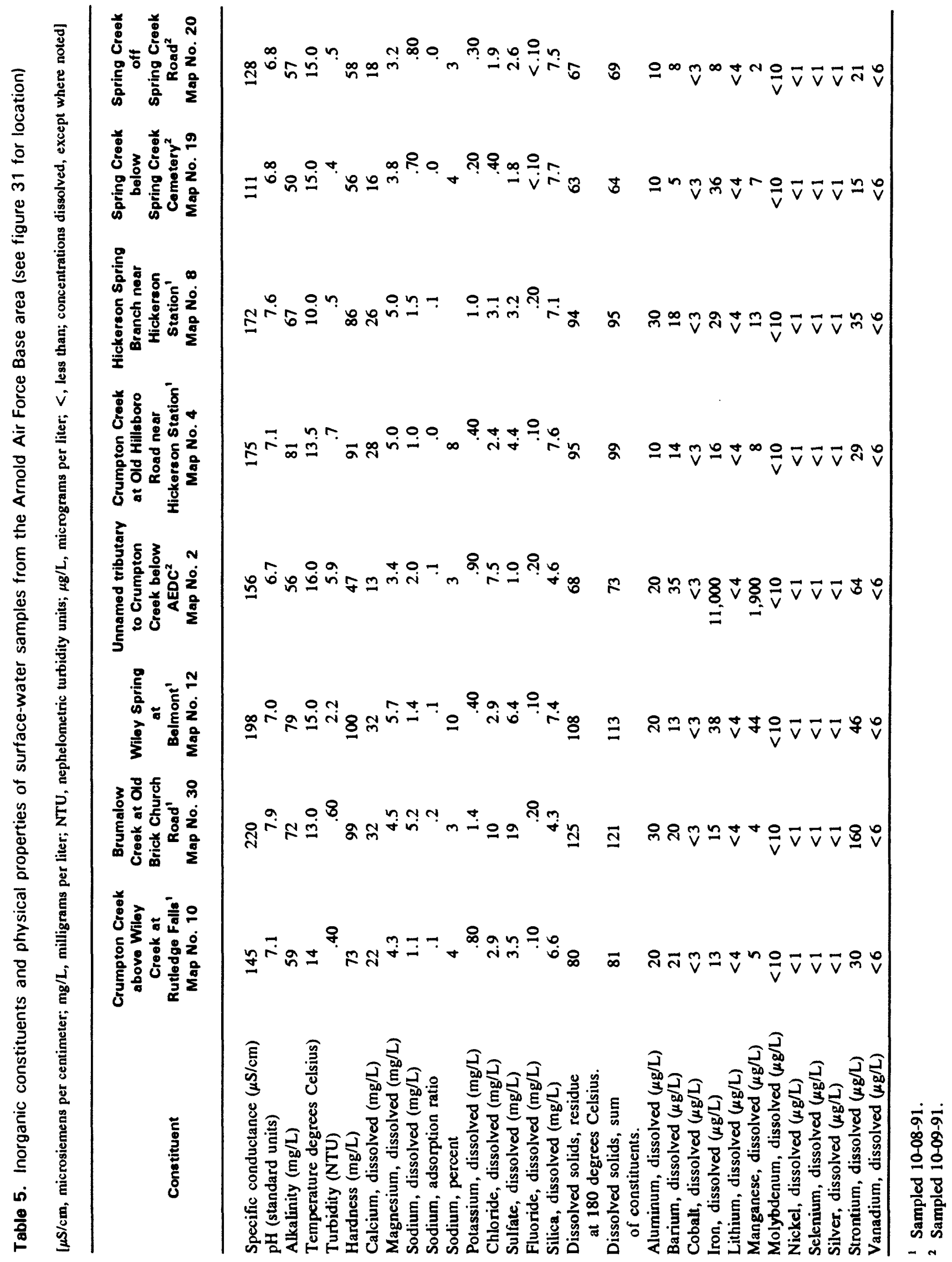

40 Hydrogeology and Simulation of Ground-Water Flow at 


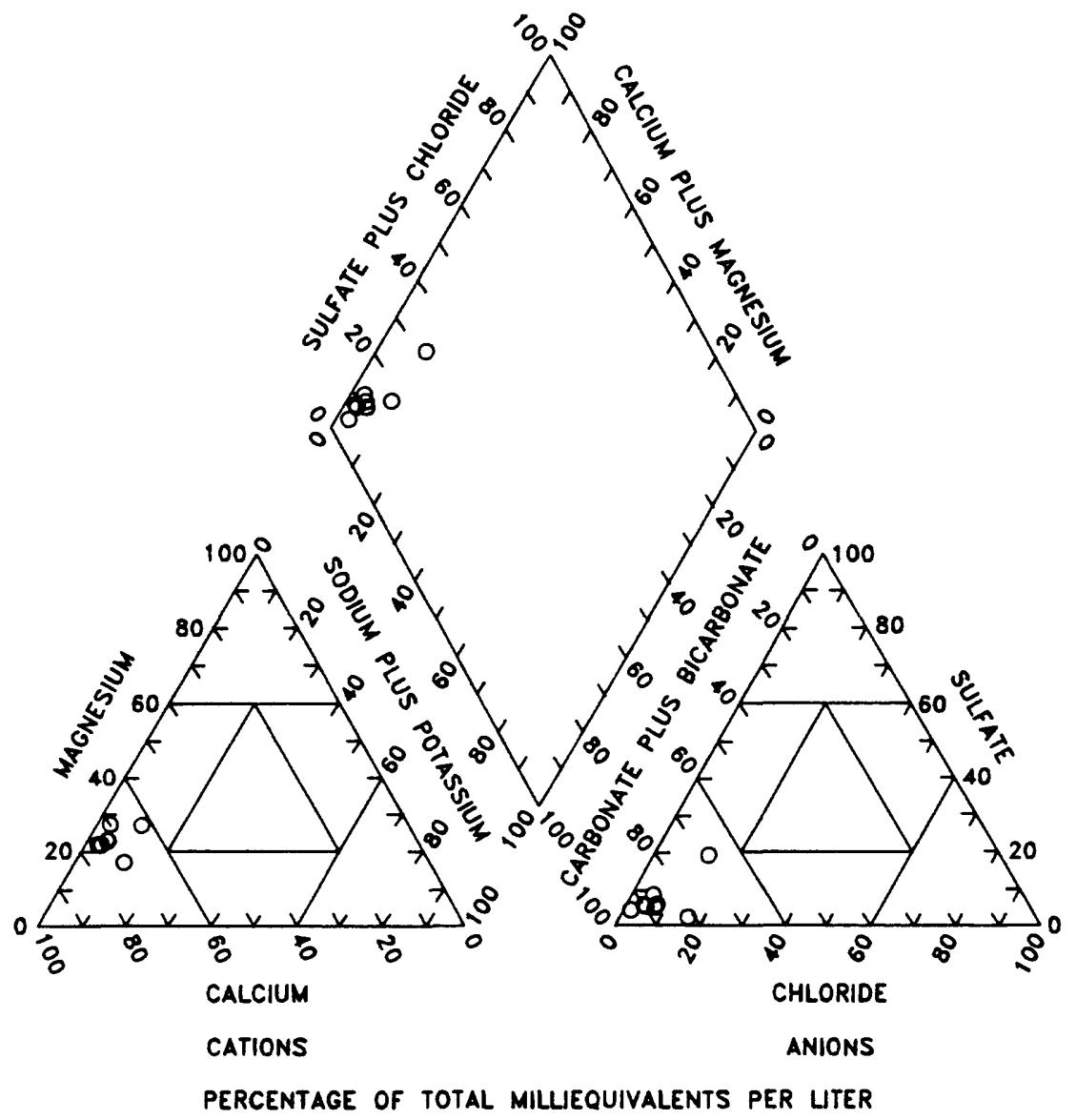

Figure 32. Chemical composition of water from surface-water stations at Arnold Air Force Base. 
The ground-water-flow model code used in this study was developed by McDonald and Harbaugh (1988) and has the following attributes:

- Flow can be simulated in a sequence of layered aquifers separated by confining units,

- Simulation of hydrologic features by several alternative methods is facilitated because of the modular design of the model, and

- Documentation and testing of the model in hydrogeologic settings similar to the study area has been conducted.

The theory and use of the model is documented thoroughly by McDonald and Harbaugh (1988) and no additional description of the general aspects of their work is included here.

\section{Model Assumptions}

The following assumptions were made in the development of the flow model of the hydrologic system in the Arnold Air Force Base study area:

1. Ground-water flow in the fractured rocks of the study area can be simulated as flow through an equivalent porous medium.

2. The bottom of the model is assumed to be a no-flow boundary, representing the Chattanooga Shale.

3. The hydraulic properties of the hydrogeologic units are homogeneous within a block of the finite-difference grid.

4. Flow within a layer is horizontal; flow (leakage) between layers is vertical.

5. The grid is aligned with primary axes of fracture traces and any anisotropy is uniform within each layer.

6. The ground-water system is at steady state and is a closed system.

7. On a regional scale, each aquifer is homogeneous.

\section{Conceptual Model}

The Highland Rim aquifer system was divided into three layers to simulate ground-water flow (fig. 33). The layers were defined on the basis of differences in physical characteristics that affect transmissivity, the consistency of potentiometric data within a layer, and the difference in potentiometric data (vertical gradient) between layers. Geochemical and potentiometric data indicate that the Chattanooga Shale is a confining unit that effectively isolates the upper Central Basin aquifer system from the Highland Rim aquifer system; therefore, flow in the upper Central Basin system was not modeled. Model layer 1 corresponds to the shallow aquifer. Layer 2 corresponds to the Manchester aquifer. Layers 1 and 2 are hydraulically well connected with vertical flow between layers. The hydraulic conductivity and geochemical data indicate that these two layers support most of the ground-water flow. Model layer 3 corresponds to the Fort Payne aquifer. Layer 3 is hydraulically connected to layer 2 , but because of its lower conductivity supports much less of the ground-water flow as indicated by the geochemical distinction between layers 1 and 2 and layer 3 .

The streams draining the area are assumed to be hydraulically connected to layer 1 through leaky streambeds. Recharge is by infiltration of precipitation. Recharge rates are higher in the topographically high areas near the divide. The system receives no subsurface recharge from outside the hydrologic boundaries. Discharge occurs supplying base-flow to streams and springs.

\section{Model Boundaries}

Because the model is three-dimensional, both vertical and horizontal boundaries need to be defined. Vertically, the upper boundary of the model is the water table, and the lower boundary is the top of the Chattanooga Shale, which serves as a no-flow boundary.

The northern boundary, Wolf Creek, the eastern boundary, Bradley Creek, and the southwestern boundary, Rock Creek, are simulated as headdependent flow (river nodes) boundaries in layer 1 , and as no-flow boundaries in layers 2 and 3 . Specified heads on the outside of these boundary rivers in layer 1 are used to simulate water discharging to these rivers from outside the modeled area so modeled and actual flow into the rivers can

42 Hydrogeology and Simulation of Ground-Water Flow at 


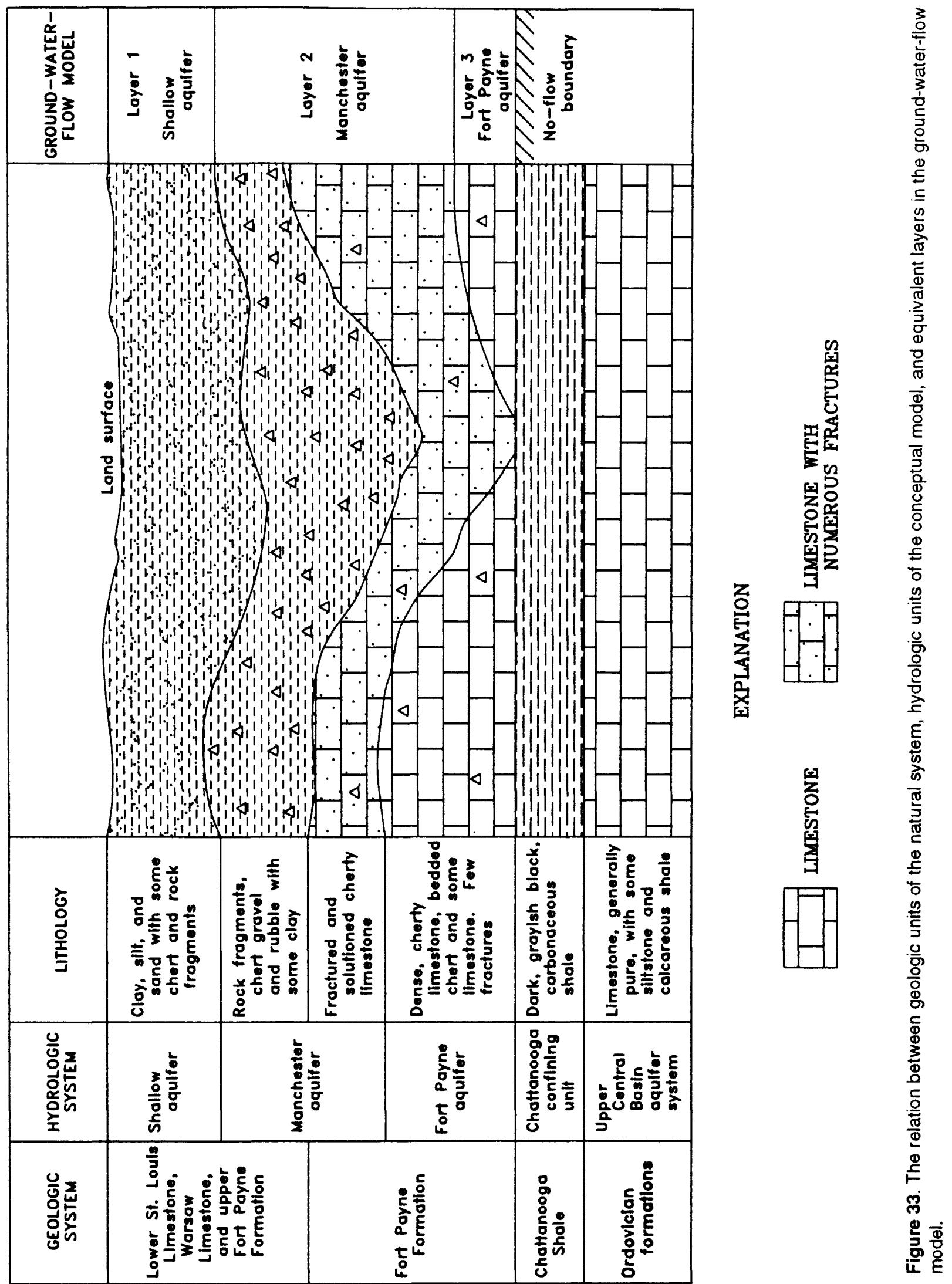


be compared directly during calibration. The western and northeastern boundaries that are parts of the drainage divide are simulated as no-flow boundaries in all three layers. The southern boundary, Woods Reservoir and Tims Ford Lake, is simulated as a constant-head boundary in layer 1 , and as a no-flow boundary in layers 2 and 3 . The northwestern boundary, where all three aquifer layers crop out along Normandy Lake, is simulated as a constant-head boundary in all three layers (fig. 34).

\section{Model Construction}

A digital ground-water-flow model represents the flow system of an area by computing heads and balancing flows for discrete subareas (cells) of the aquifers. A finite-difference approximation of the continuous differential equation is solved for each block for specified boundary conditions, aquifer hydraulic properties, and pumping stresses (McDonald and Harbrough, 1988). An orthogonal grid defines the arrangement of cells in the model.

The model grid used for the AAFB model is a 237-square mile rectangle and includes the study area; however, only 167-square miles are active in the model. The grid includes a matrix of 106 by 95 grid cells (fig. 35). Each layer has 10,070 grid cells, of which 8,898 are active.

The grid cells are variably sized to accommodate areas where field data collection is more concentrated and to separate monitoring wells into individual grid cells for comparison of field data with simulated values. The dimensions of the smallest grid cells, located in the center of AEDC, Camp Forrest, and Coffee County landfill, are 250 feet on each side, and the largest grid cells, near the model boundaries, are 2,000 feet on each side. The smallest cells were used in areas of known ground-water contamination to provide greater detail for particle tracking and other future analyses. The grid is oriented N. $55^{\circ}$ E., N. $35^{\circ}$ W. so that flow between model cells is parallel to the flow within the fractures in the aquifers (J.V. Brahana, U.S. Geological Survey, written commun., 1990).
Recharge rates are based on an average annual recharge for the Tullahoma-Manchester area as discussed earlier. Initial recharge in the model was $8 \mathrm{in} / \mathrm{yr}$ and was uniformly distributed throughout layer 1.

The streams were simulated as river nodes in layer 1. River nodes simulate leakage to and from the ground-water system based on the difference between river stage and the head in the aquifer, and the streambed conductance. Conductance $(\mathrm{C})$, in feet squared per day, is a function of the hydraulic properties of the streambed sediments and the geometry of the streambed and is computed by:

$$
C=K A / b
$$

where $K$ is vertical hydraulic conductivity of the streambed, in feet per day;

$A$ is the area of the stream within the node, in square feet; and;

$b$ is the streambed thickness, in feet.

Thickness of the streambeds was assumed to be 1 foot to simplify calculations; vertical hydraulic conductivity of $1 \mathrm{ft} / \mathrm{d}$ was used initially for all streams. The initial values could be changed during calibration if simulated seepage to the streams did not approximate measured seepage. The streambed altitude within each river node was determined using the altitude of that stream from a topographic map. The stream stage was then assumed to be 1 foot above the streambed. Widths of the streams were assigned based on field observations and measurements. Stream lengths were determined using Geographic Information System software to intersect the hydrography coverage with the model grid and calculate stream lengths within each cell.

Stream reaches that are normally dry in late summer and fall were modeled as drains because these nodes can gain water from the ground-water system, but do not contribute water to the system. Drain nodes simulate leakage from the groundwater system on the basis of the difference between the head in the aquifer and the streambed altitude and the streambed conductance. Altitudes used for the streambeds for the drains were determined from a topographic map. The conductances

44 Hydrogeology and Simulation of Ground-Water Flow at 

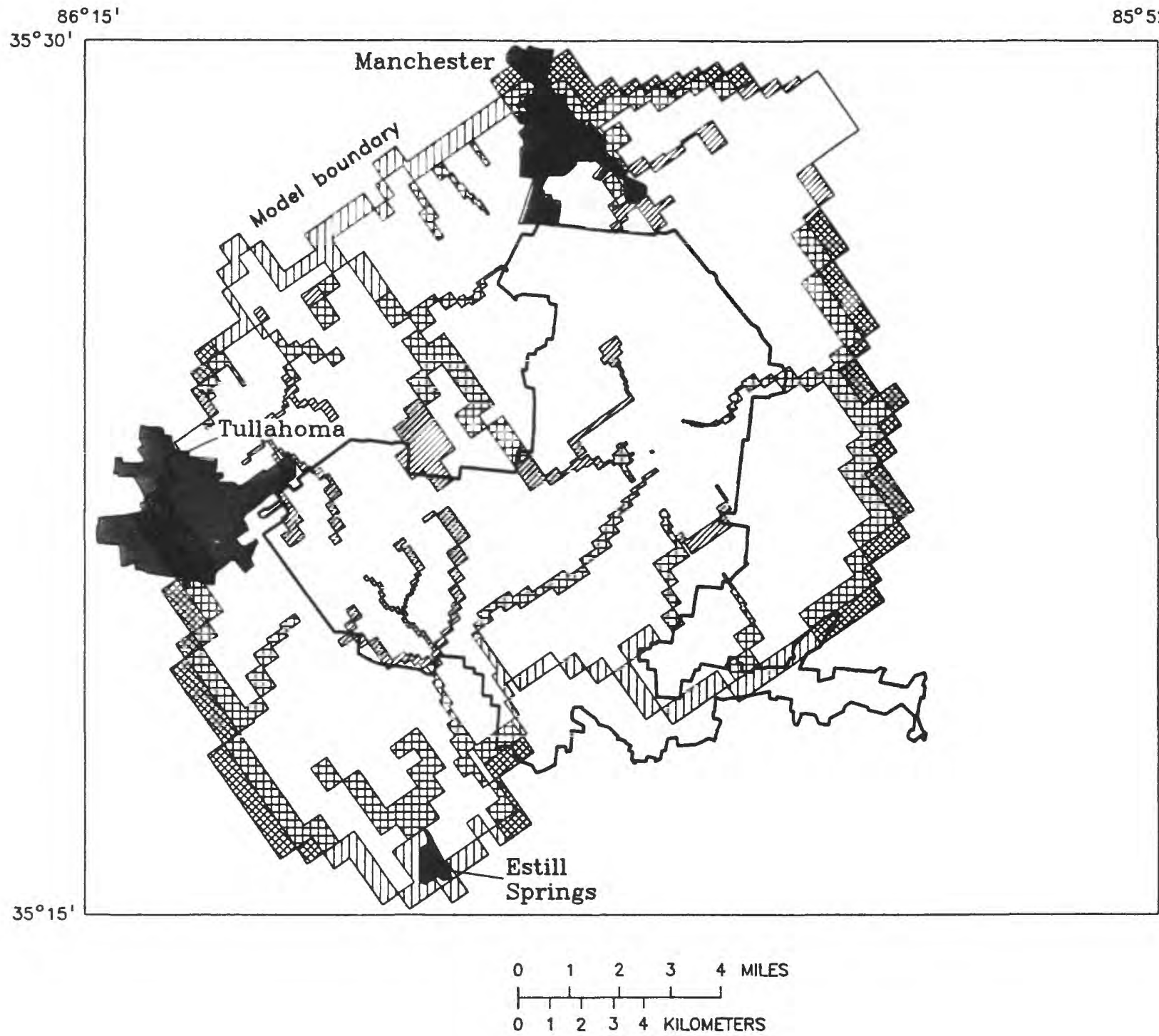

EXPLANATION
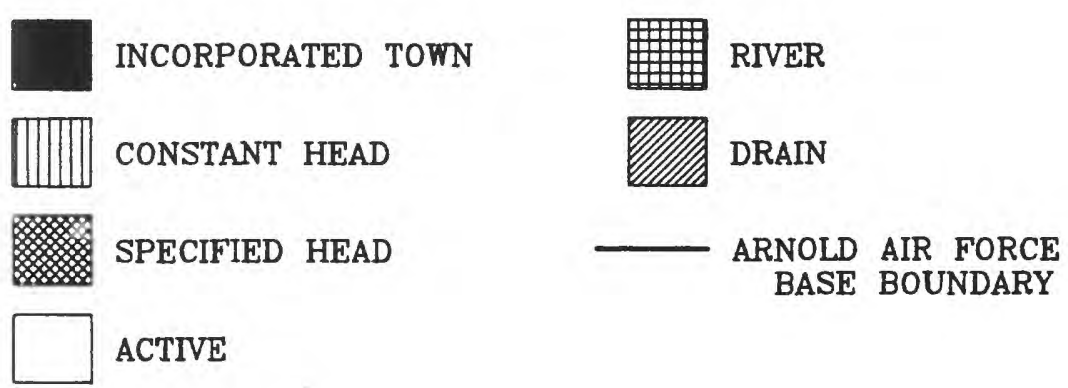

Figure 34. Grid cell types for the digital flow model. 


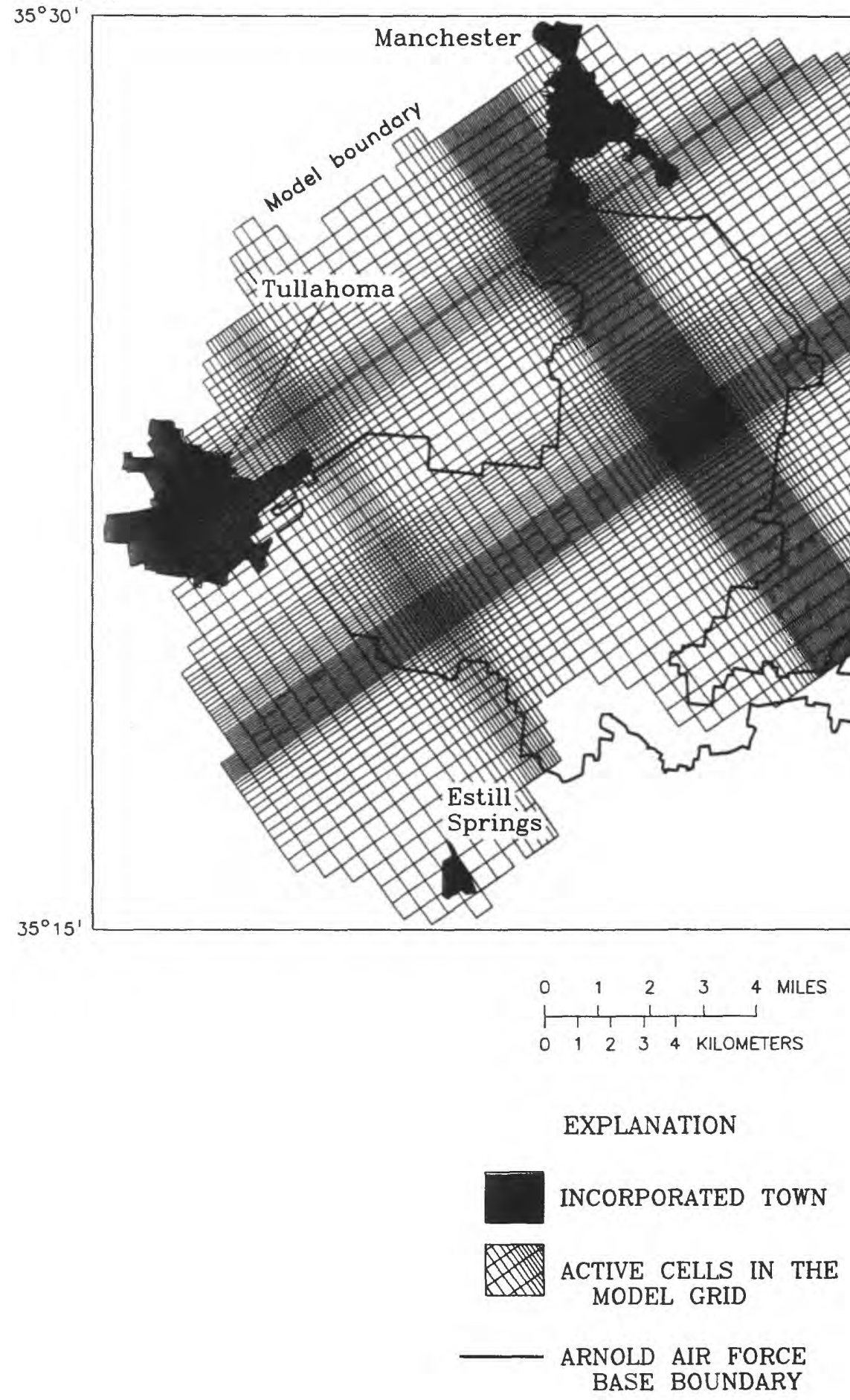

Figure 35. Active area of model grid used for the Arnold Air Force Base study area. 
for these drains were calculated using the same equation and assumptions as in the river nodes.

Transmissivity for each layer was calculated from a uniform value of hydraulic conductivity and the variable thickness of each layer. Initial uniform values of hydraulic conductivity used for layer 1,2 , and 3 were $9 \mathrm{ft} / \mathrm{d}, 28 \mathrm{ft} / \mathrm{d}$ and $1.6 \mathrm{ft} / \mathrm{d}$, respectively. These were median values calculated from previous investigations. Thicknesses ranged from 5 to 75 feet for layer 1,5 to 50 feet for layer 2 , and 20 to 200 feet for layer 3 (figs. 36, 37, and 38). This results in initial transmissivities of 45 to $680 \mathrm{ft}^{2} / \mathrm{d}$ in layer 1,140 to $1,400 \mathrm{ft}^{2} / \mathrm{d}$ in layer 2 , and 32 to $320 \mathrm{ft}^{2} / \mathrm{d}$ in layer 3 .

The model layers were assumed to be hydraulically well connected and not separated by confining materials; therefore, the vertical leakance between layers was calculated based on the aquifer properties. Vertical leakance, in feet per day per foot, between adjacent layers was calculated by McDonald and Harbaugh (1988):

$$
\text { VERTICAL LEAKANCE }=\frac{2 K_{L a} K_{L c}}{K_{L a} b_{L c}+K_{L c} b_{L c}}
$$

where $K$ is vertical hydraulic conductivity, in feet per day;

$b$ is thickness, in feet;

La is the uppermost layer; and

$L c \quad$ is the lowermost layer.

The vertical leakance between layers was calculated using an average thickness for each layer. In order to calculate the largest reasonable vertical leakance between model layers for initial runs, vertical hydraulic conductivity was assumed to be equal to horizontal conductivity. Initial vertical leakance between layers 1 and 2 is $3.4(\mathrm{ft} /$ day) $/ \mathrm{ft}$ and between layers 2 and 3 is $5.8 \mathrm{x}$ $10^{-2}(\mathrm{ft} / \mathrm{day}) / \mathrm{ft}$.

The stress on the ground-water-flow system includes manmade withdrawals. Dewatering of the aquifers at the $\mathrm{J} 4$ facility has a local effect on the ground-water-flow system. Pumping from sumps in the bottom of J4 ensures that water levels in the aquifers remain tens of feet below the natural level. Between 100 and $200 \mathrm{gal} / \mathrm{min}$ of ground water are continuously pumped from the J4 test cell. The grid cell containing J4 was simulated as a drain in each aquifer.

\section{Model Calibration}

The process of adjusting the input variables to produce the best match between simulated and observed water levels and flows is known as calibration. The digital model developed for this particular study used a steady-state simulation to model the natural system under average annual conditions. It was calibrated by minimizing the difference between simulated and observed water levels and streamflows. The month that best represents average annual water-level conditions is June 1991. However, because water levels in 65 new wells drilled to help model calibration were still recovering from sampling at that time, the month having the most complete record of water levels after this period was August 1991. Comparison between June and August water levels indicate a maximum water-level difference of \pm 2 feet. The simulated water levels were compared with 158 water levels measured at wells during August 1991. Water levels were used for comparison in 42 nodes ( 43 wells) for layer 1,82 nodes (91 wells) for layer 2 , and 22 nodes ( 24 wells) for layer 3. The range of average-annual groundwater discharge to streams was estimated from November 1991 seepage measurements and other available historic measurements.

The model was calibrated by adjusting global multipliers of transmissivity of the shallow, Manchester, and Fort Payne aquifers. Calibrated values for hydraulic properties were within the range of those determined by aquifer tests, slug tests, and specific-capacity tests as reported in previous site-specific investigations at the AAFB. Calibrated values of hydraulic conductivity for the shallow, Manchester, and Fort Payne aquifers were 73,64 , and 1.7 feet per day, respectively. The 

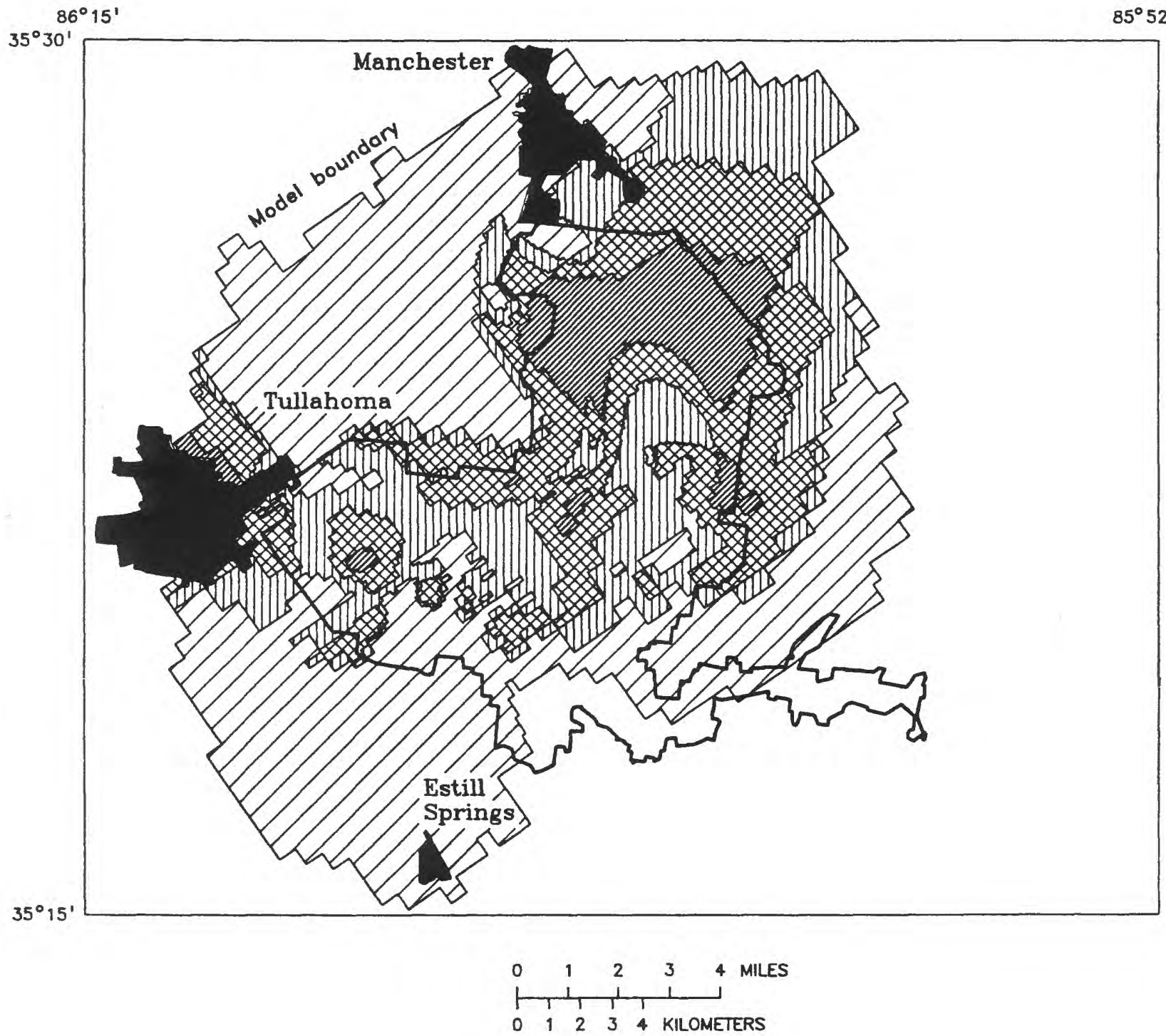

\section{EXPLANATION}

INCORPORATED TOWN

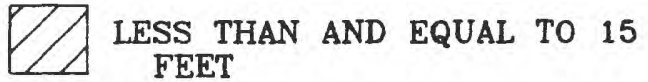

GREATER THAN 15 FEET AND LESS THAN OR EQUAL TO 30 FEET

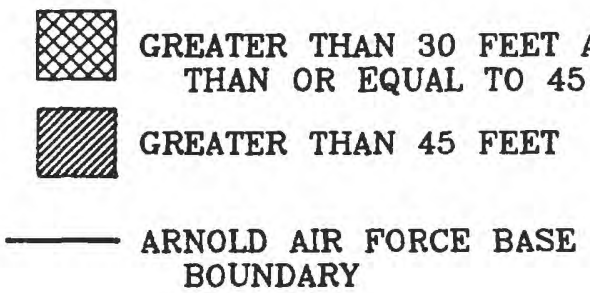

BOUNDARY

Figure 36. Finite-difference grid showing range of thicknesses of layer 1 of ground-water-flow model of Arnold Air Force Base study area.

48 Hydrogeology and Simulation of Ground-Water Flow at

Arnold Air Force Base, Coffee and Franklin Counties, Tennessee 

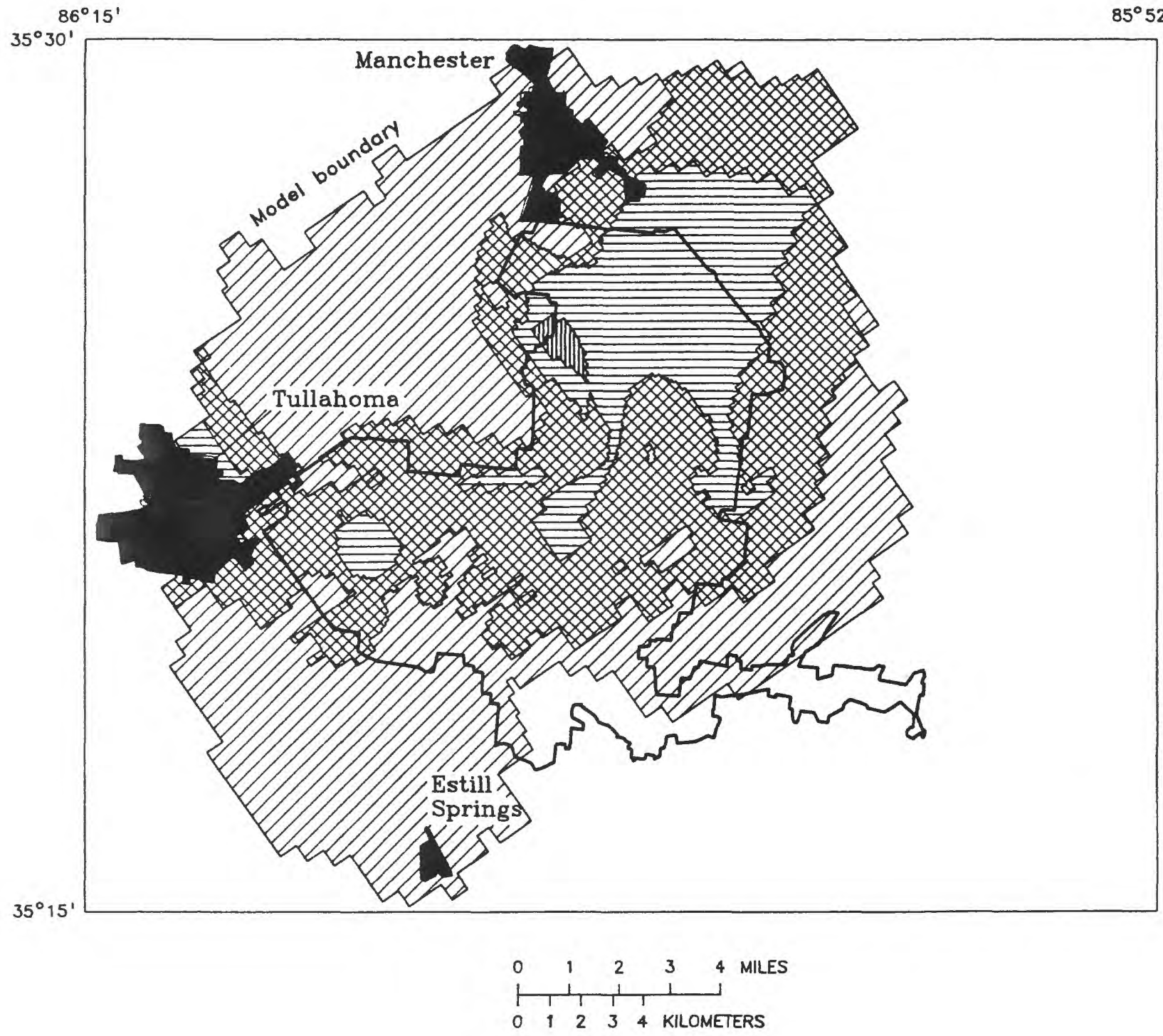

EXPLANATION

INCORPORATED TOWN

LESS THAN AND EQUAL TO 10 FEET

GREATER THAN 10 FEET AND LESS THAN OR EQUAL TO 25 FEET

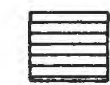

GREATER THAN 25 FEET AND LESS THAN OR EQUAL TO 40 FEET

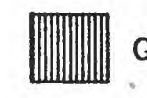

GREATER THAN 40 FEET

ARNOLD AIR FORCE BASE BOUNDARY

Figure 37. Finite-difference grid showing range of thicknesses of layer 2 of ground-water-flow model of Arnold Air Force Base study area. 

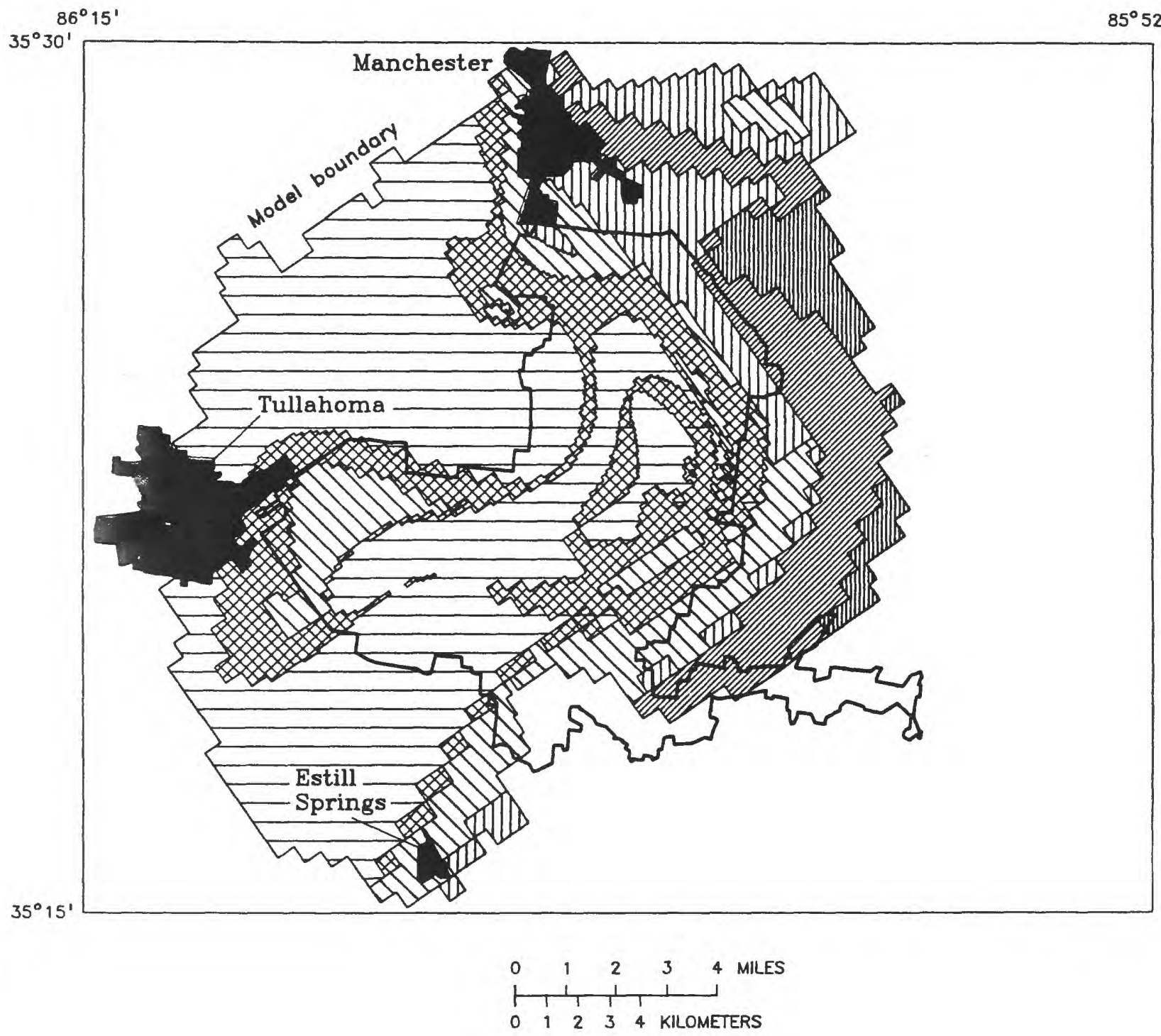

EXPLANATION

INCORPORATED TOWN

LESS THAN AND EQUAL TO 30 FEET

GREATER THAN 30 FEET AND LESS THAN OR EQUAL TO 60 FEET

GREATER THAN 60 FEET AND LESS THAN OR EQUAL TO 90 FEET

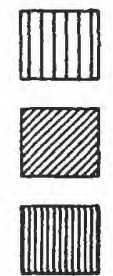

GREATER THAN 90 FEET AND LESS THAN OR EQUAL TO 120 FEET

GREATER THAN 120 FEET AND LESS THAN OR EQUAL TO 150 FEET

GREATER THAN 150 FEET

\section{ARNOLD AIR FORCE BASE} BOUNDARY

Figure 38. Finite-difference grid showing range of thicknesses of layer 3 of ground-water-flow model of Arnold Air Force Base study area.

50 Hydrogeology and Simulation of Ground-Water Flow at Arnold Air Force Base, Coffee and Franklin Counties. Tennessee 
leakage between aquifer layers was modified by uniformly adjusting the vertical leakance as the transmissivity was adjusted. Tributary streams were added as drains where initially these small streams were thought to have played a minor role in the flow regime. This addition was necessary to help decrease simulated heads that were hundreds of feet too high. Streams originally thought to be minor did, in fact, play an important role in the digital model by allowing the model to properly simulate conditions close to observed conditions. Streambed conductance was adjusted during calibration, where necessary, so that the simulated flow between the aquifer and river would fall within the range of observed base-flow stream measurements. Recharge was adjusted so that a higher recharge rate, $10 \mathrm{in} / \mathrm{yr}$, occurs uniformly along the drainage divide, while a lower rate, $6 \mathrm{in} / \mathrm{yr}$, was distributed throughout the remaining area (fig. 39). The recharge value was kept well within the range of average annual recharge reported for this area of Tennessee (Hoos, 1990).

Several methods are used in finding the "best" model. One method is an error analysis of simulated and observed water levels at nodes representing control points. The root mean square error (RMSE) is used to judge how closely the model simulation matches the natural system, defined by measured water levels in a network of observation wells. The RMSE was calculated as a measure of difference between model-calculated heads and observed heads. The RMSE is represented by the equation:

$$
R M S E=\sqrt{\frac{\sum_{i=1}^{N}\left(H^{c}-H\right)^{2}}{N}}
$$

where $H^{c}$ is calculated head, in feet, at a model node;

$H^{\circ}$ is observed heads, in feet;

$N$ is the number of comparison points; and

$i$ is a subscript that defines any specific comparison point, varying between 1 and $N$.
The model that most closely simulated water levels in the shallow, Manchester, and Fort Payne aquifers had RMSE values of 12, 14, and 16 feet for each layer, respectively (table 6). Seventy-three percent of all water levels were within 15 feet of the observed water levels. Model-simulated water levels for each layer (fig. 40) are considered to be a good representation of the flow system.

The comparison between the observed and simulated streamflows was made using ZONEBUDGET (Harbaugh, 1990), a computer program that calculates subregional water budgets using results from the digital model code used in this study. The program was used as another tool for comparison. The ranges of observed streamflows were compared to simulated streamflows. Simulated streamflows compare reasonably well with the range of baseflows estimated from measurements (table 7).

The calibrated model simulated $162 \mathrm{gal} / \mathrm{min}$ draining from the J4 test cell. This amount is within the observed range of 100 to $200 \mathrm{gal} / \mathrm{min}$.

Components of the steady-state water budget of the simulated system are shown in figure 41 . The largest source of water to the ground-water system is recharge $\left(78.2 \mathrm{ft}^{3} / \mathrm{s}\right)$. The only other source of water to the modeled area is river leakage $\left(37.7 \mathrm{ft}^{3} / \mathrm{s}\right)$. The boundary inflow $\left(67.2 \mathrm{ft}^{3} / \mathrm{s}\right)$ should not be considered part of the water budget for the modeled area. This represents the flow of water from specified head cells placed outside the boundary river nodes to simulate ground water from outside the modeled area discharging to boundary river nodes. This allows direct comparison between simulated flows in boundary rivers and observed flows. All of this flow discharges directly to boundary river nodes; no underflow occurs so this is not a source of water to the modeled area.

Most of the water $\left(146.7 \mathrm{ft}^{3} / \mathrm{s}\right)$ discharges from the ground-water system as seepage to rivers and drains. The remaining amount discharges to constant head cells at Woods Reservoir and Tims Ford Lake $\left(29.3 \mathrm{ft}^{3} / \mathrm{s}\right)$ or to constant head cells representing many small seeps and springs along the Highland Rim escarpment $\left(7.3 \mathrm{ft}^{3} / \mathrm{s}\right)$. Of the water entering layer 1 , approximately 78 percent reaches layer 2, while only 9 percent reaches layer 3 . 


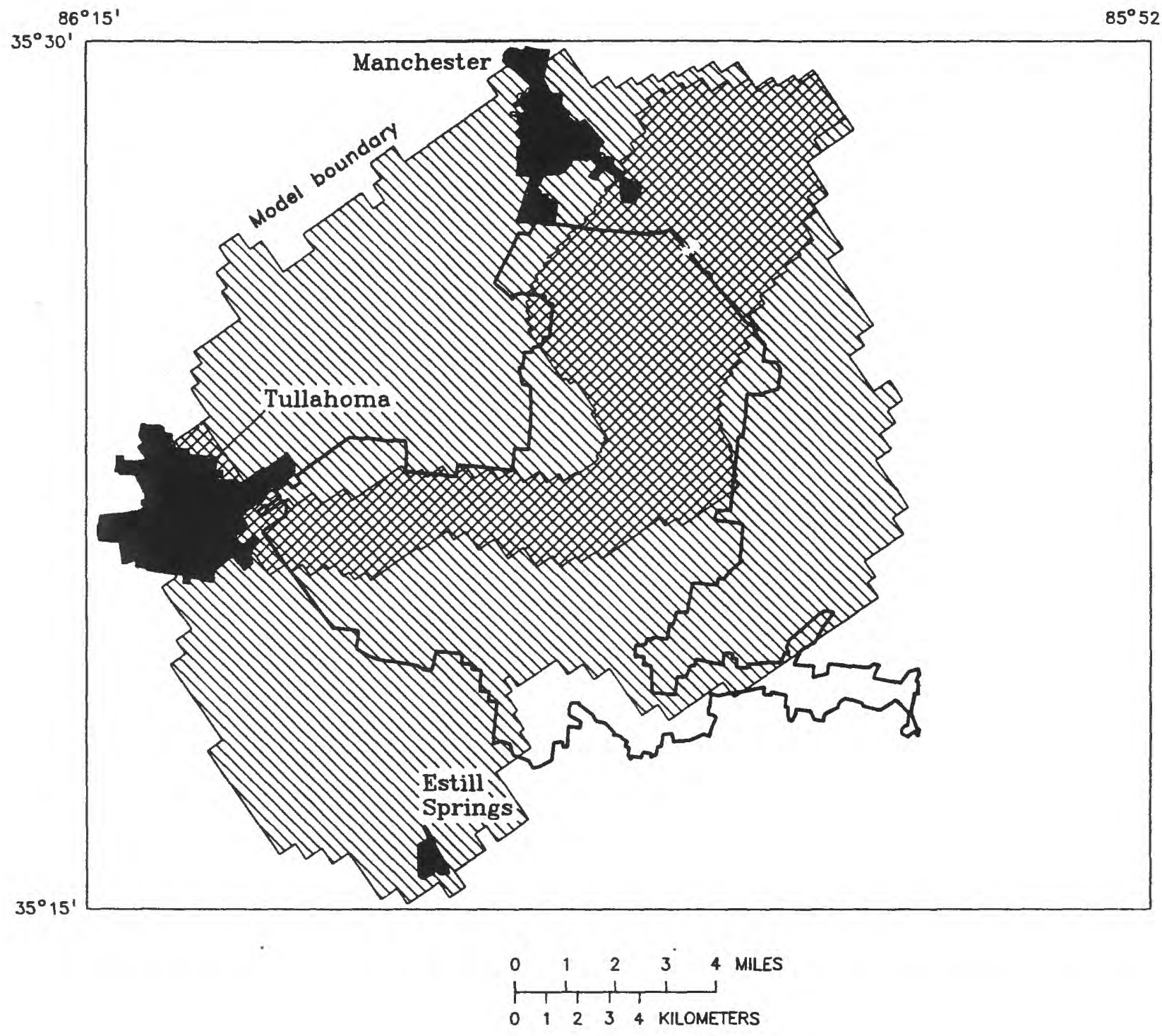

EXPLANATION

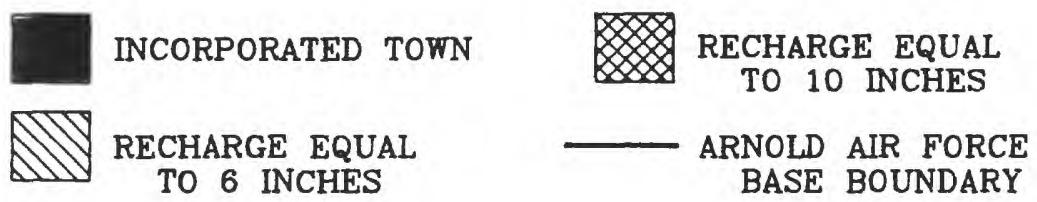

Figure 39. Distribution of simulated recharge rates of ground-water-flow model of Arnold Air Force Base study area.

52 Hydrogeology and Simulation of Ground-Water Flow at

Arnold Air Force Base, Coffee and Franklin Counties, Tennessee 
Table 6. Comparison of simulated to estimated average-annual water levels for ground-water-flow model of Arnold Air Force Base study area

[RMSE, root mean square error]

\begin{tabular}{|c|c|c|c|c|c|c|c|}
\hline & \multirow[t]{2}{*}{ RMSE } & \multicolumn{3}{|c|}{$\begin{array}{l}\text { Percentage of eimulated water lovels within } \\
\text { estimated average annual water levels of }\end{array}$} & \multicolumn{3}{|c|}{$\begin{array}{l}\text { Number of wells compared to total number of } \\
\text { wells for which simulated water levels were within } \\
\text { estimated average annual water levele of }\end{array}$} \\
\hline & & 20 feet & 15 feet & 10 feet & 20 feet & 15 feet & 10 feet \\
\hline Layer 1 & 12 feet & 93 & 79 & 60 & 40 of 43 & 34 of 43 & 26 of 43 \\
\hline Layer 2 & 14 feet & 81 & 71 & 59 & 74 of 91 & 65 of 91 & 54 of 91 \\
\hline Layer 3 & 16 feet & 79 & 67 & 46 & 19 of 24 & 16 of 24 & 11 of 24 \\
\hline All layers & 14 feet & 84 & 66 & 65 & 133 of 158 & 104 of 158 & 102 of 158 \\
\hline
\end{tabular}

Table 7. Comparison of model-simulated streamflow to estimated average-annual stream base flow for groundwater-flow model of Arnold Air Force Base study area

\begin{tabular}{lcc}
\hline & $\begin{array}{c}\text { Model simulated } \\
\text { streamflow, in cubic } \\
\text { foet per second }\end{array}$ & $\begin{array}{c}\text { Range of estimated average } \\
\text { annual stream basoflow, } \\
\text { in cubic foet per second }\end{array}$ \\
\hline Spring Creek & 5 & $5-15$ \\
Little Duck above Wolf & 4 & $4-8$ \\
Crumpton and Wiley Creek & 16 & $5-15$ \\
Bradley Creek & 21 & $9-18$ \\
Little Duck and Wolf Creek & 9 & $10-20$ \\
Mouth of Spring Creek & 8 & $9-27$ \\
Rock Creek & 35 & $13-39$ \\
\hline
\end{tabular}



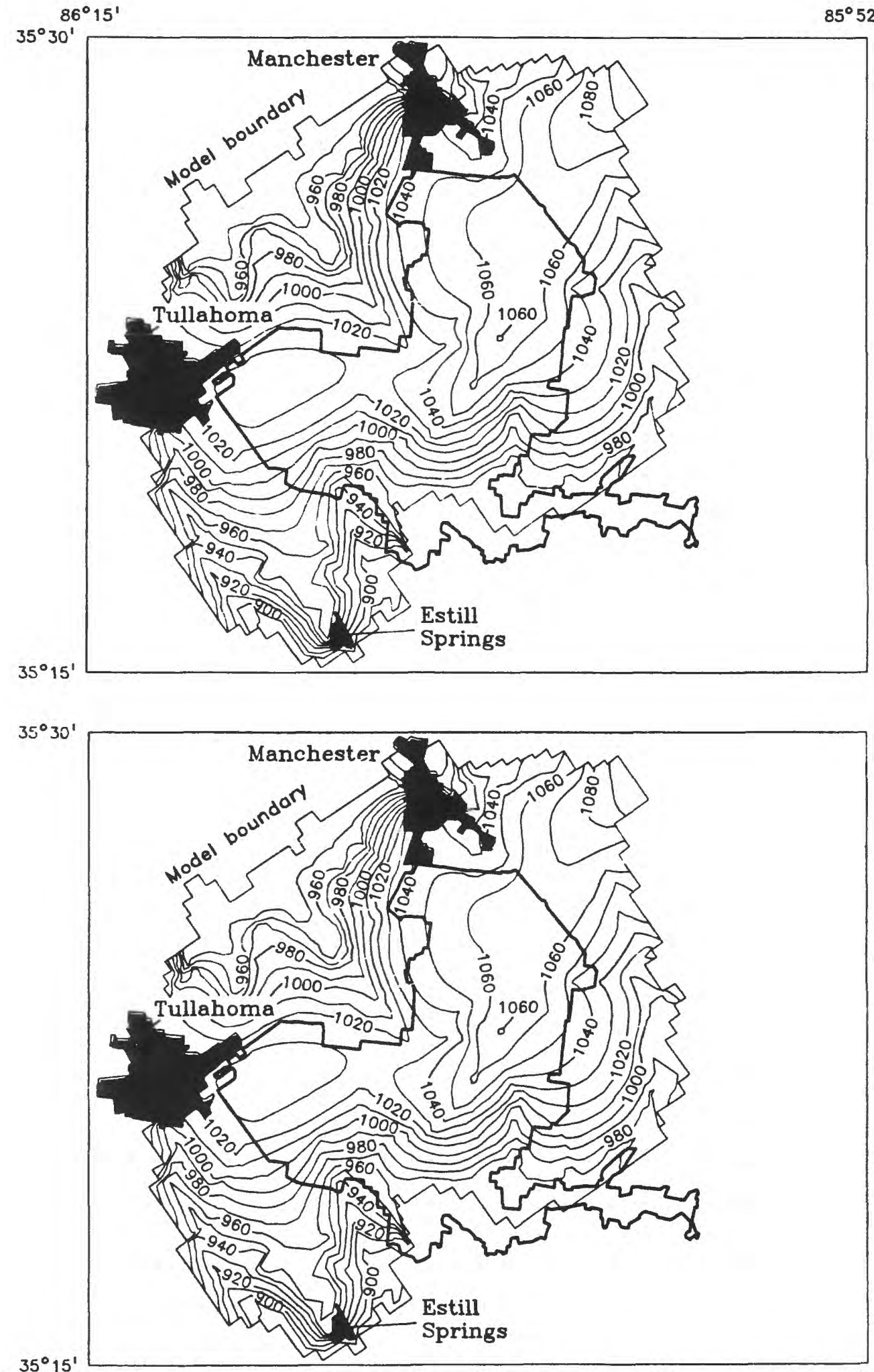

Figure 40. Model-simulated water levels in layers 1, 2, and 3 for ground-water-flow model of Arnold Air Force Base study area. 

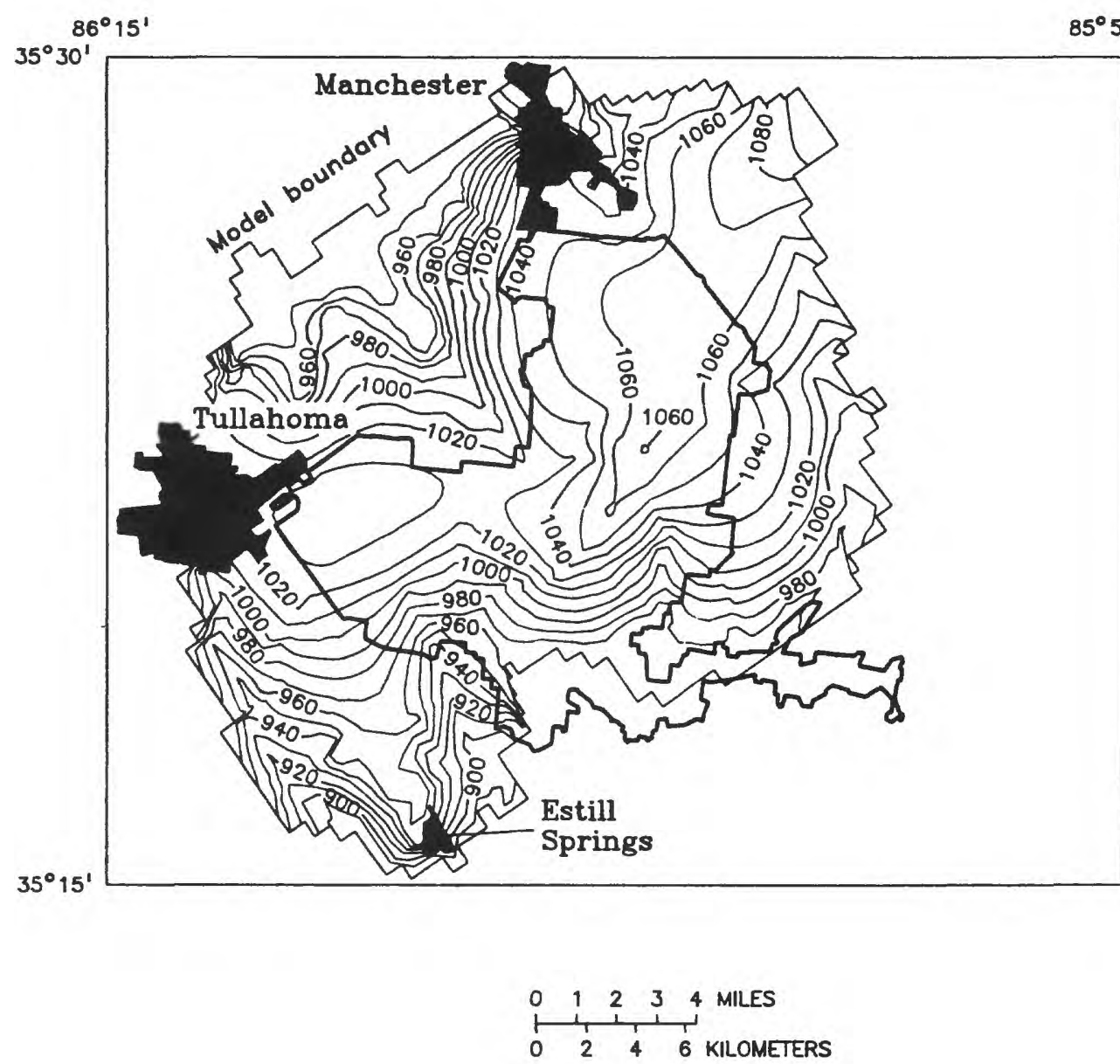

\section{EXPLANATION}

INCORPORATED TOWN

-900- POTENTIOMETRIC SURFACE CONTOUR--

Contour interval 10 feet. Datum

is sea level

Figure 40. Model-simulated water levels in layers 1, 2, and 3 for ground-water-flow model of Arnold Air Force Base study area--Continued. 
LAYER 1

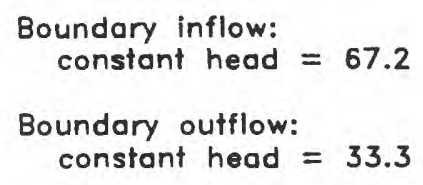

LAYER 2

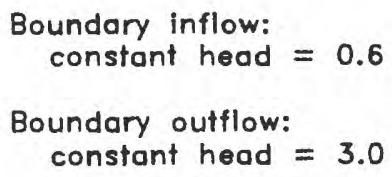

\section{LAYER 3}
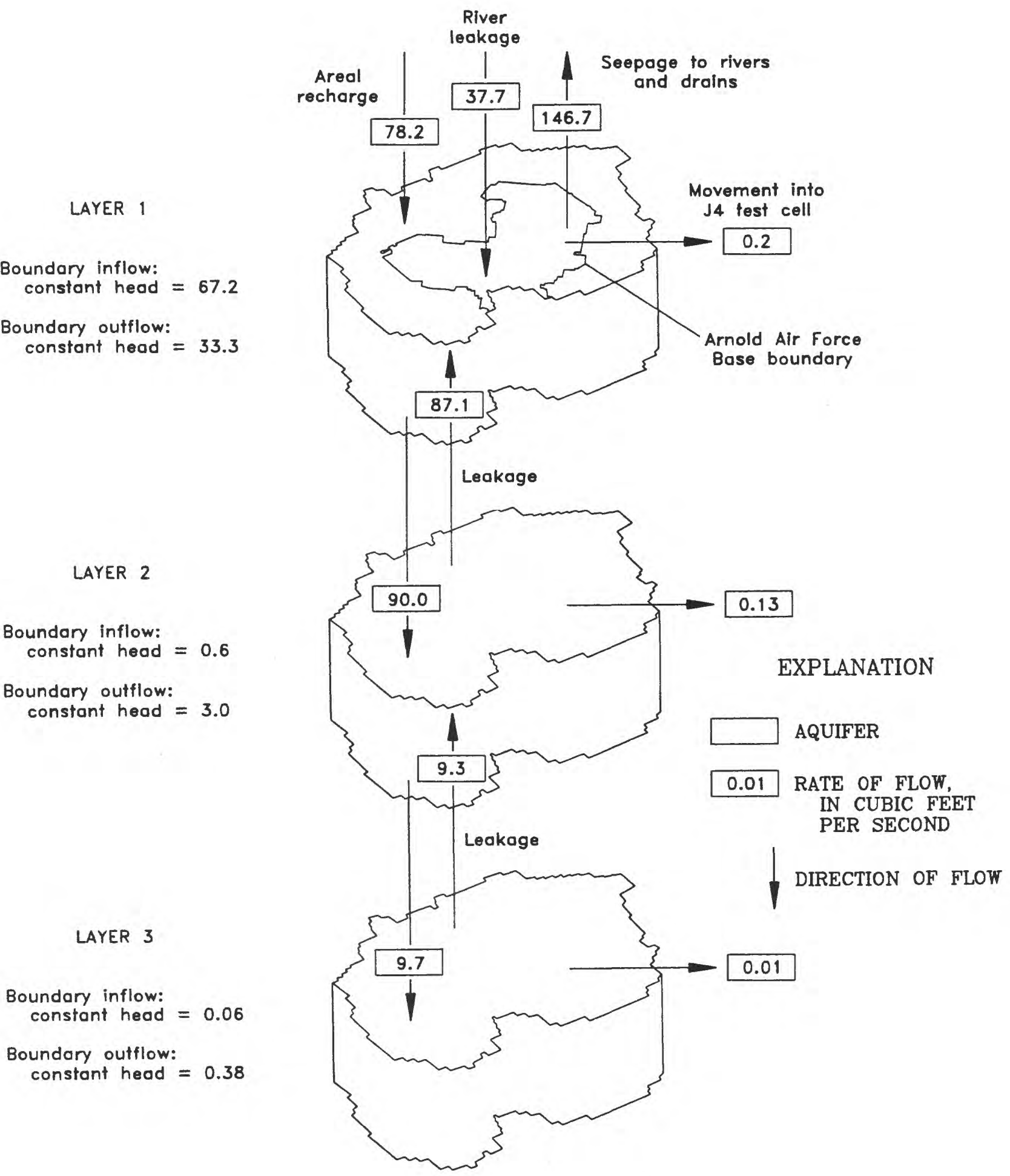

Figure 41. Distribution of water-budget components among the layers of the digital flow model for the Arnold Air Force Base study area. 


\section{Sensitivity Analysis}

Sensitivity of the model to changes in various model-input parameters was evaluated to indicate the degree of importance of individual parameters to the simulation of ground-water flow. Sensitivity analysis can provide an indication of the uniqueness of the model calibration. For example, if similar model results are obtained when a modelinput parameter is varied over a large range of values from the calibrated value, then the model is insensitive to that parameter and the model solution can be considered as non-unique. Additionally, if the model is insensitive to a parameter, then obtaining additional field information to refine knowledge of that parameter would do little to improve model results.

The parameters evaluated were recharge, hydraulic conductivity of the layers, vertical conductance between layers, conductance of streambeds, and horizontal anisotropy. Each parameter was adjusted uniformly over the entire model area, and the RMSE was calculated and compared to the calibrated RMSE. The parameters were evaluated independently except for anisotropy and river and drain conductances. For the anisotropy analysis, layers 1 and 2 were varied simultaneously while isotropic conditions were assumed in layer 3 . River and drain conductances were varied together using a constant multiplier. All other parameters were held constant while the tested parameter was varied. The vertical conductance between the aquifer layers was adjusted individually.

The effects of these variations on calculated water levels in the three aquifers were evaluated by RMSE comparison of observed and simulated water levels. The results of the sensitivity analysis were graphed and are shown in figures 42,43 , and 44 for the three aquifers.

Hydraulic conductivity was adjusted individually for each of the three layers, while the other two layers were held at the calibrated values. The model is most sensitive to increases in hydraulic conductivity for layers 1 and 2 and less sensitive to decreases in hydraulic conductivity in layers 1 and 2. The calculated heads for all three aquifers are insensitive to any decrease in hydraulic conductivity in layer 3 (fig. 42).

The model is sensitive to decreases in vertical conductance between layers 1 and 2 . The model is insensitive to increases in vertical conductance between layers 1 and 2 and any change in the vertical conductance between layers 2 and 3 (fig. 43).

River and drain conductances were tested simultaneously. The model is sensitive to decreases in river and drain conductances; it becomes unstable when increases greater than 10 times the calibrated value are tested (fig. 43).

The model is sensitive to increases and decreases in recharge (fig. 44). An average recharge rate for the entire study area of 7.1 inches per year was used. This average reflects dividing the study area into a 45-square-mile area along the drainage divide where a recharge rate of 10 inches per year was used, and a 122-square-mile area of 6 inches per year which encompasses the remainder of the study area.

Anisotropy was tested for layers 1 and 2 simultaneously. This parameter was tested for both column-to-row and the row-to-column anisotropy. In the first case, the anisotropy factor within the model was adjusted to increase and decrease the hydraulic conductivity in the column direction while the hydraulic conductivity in the row direction was held at the calibrated value. The second case tested the row-to-column anisotropy by using the calibrated hydraulic conductivity in the column direction and increasing and decreasing the hydraulic conductivity in the row direction. This was done by increasing or decreasing the hydraulic conductivity for each layer of concern and then using the reciprocal factor on the actual anisotropy parameter in the model. The model is more sensitive to column-to-row anisotropy (changes in the hydraulic conductivity of the columns) than to row-to-column anisotropy. The results of both cases show no anisotropy results in the lowest RMSE (fig. 44).

These results show the model is most sensitive to increases in hydraulic conductivity of layers 1 and 

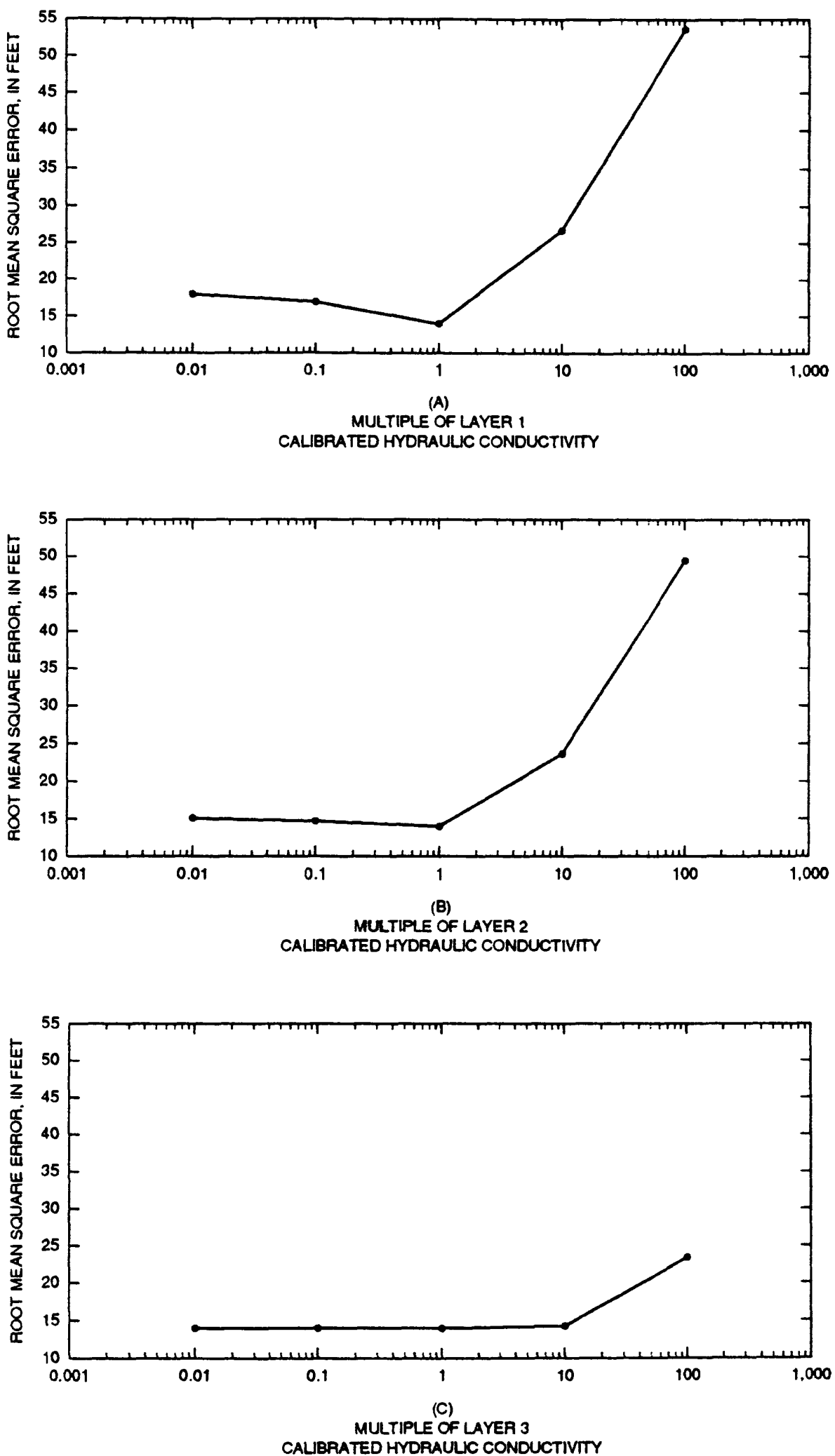

Figure 42. Sensitivity of ground-water-flow model of Arnold Air Force Base study area to adjustments in hydraulic conductivity in layer 1, layer 2, and layer 3.

58 Hydrogeology and Simulation of Ground-Water Flow at Arnold Air Force Base, Coffee and Franklin Counties, Tennessee 

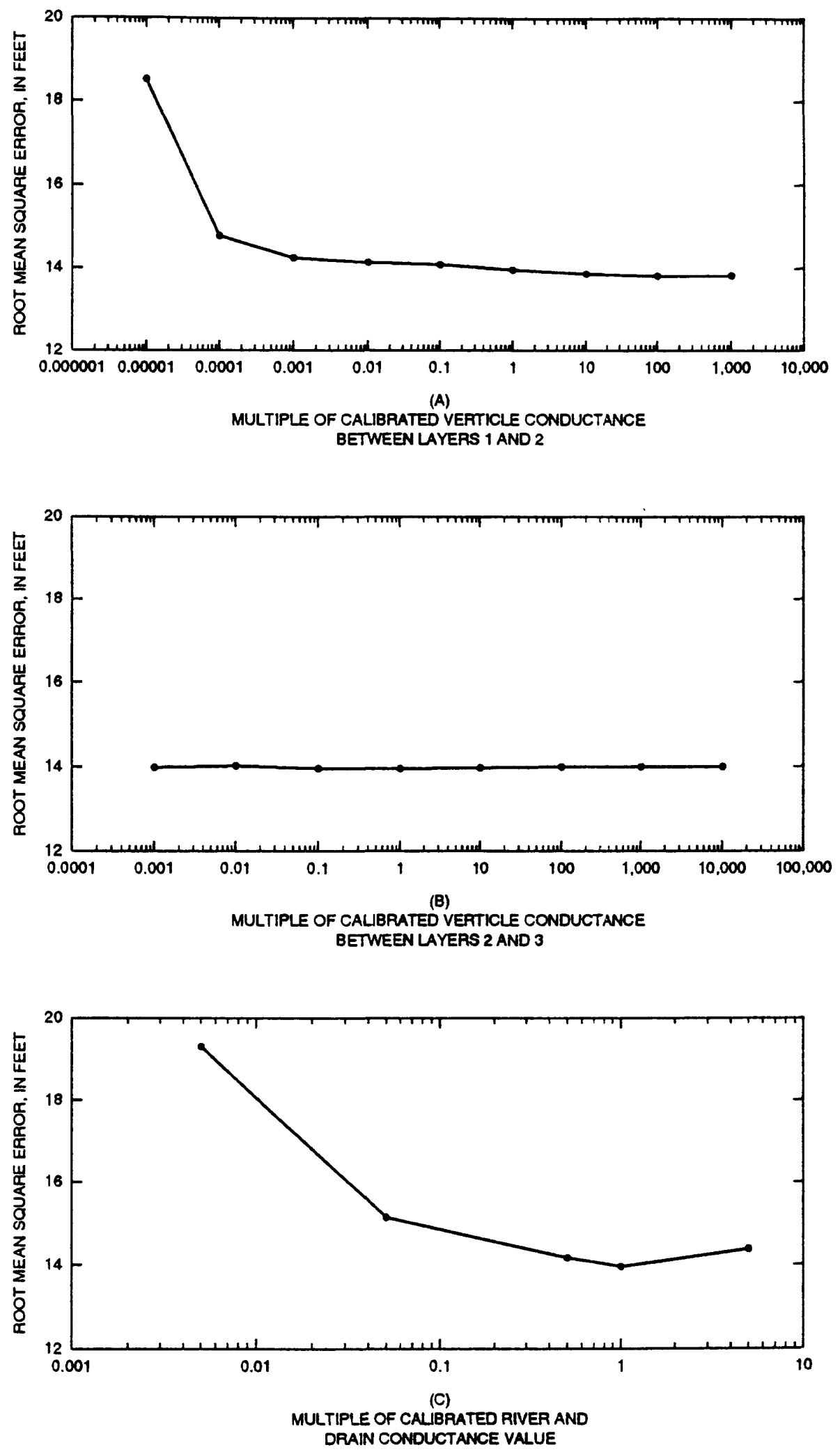

Figure 43. Sensitivity of ground-water-flow model of Arnold Air Force Base study area to adjustments in vertical conductance between layers 1 and 2, and layers 2 and 3; and adjustments in river and drain conductance. 


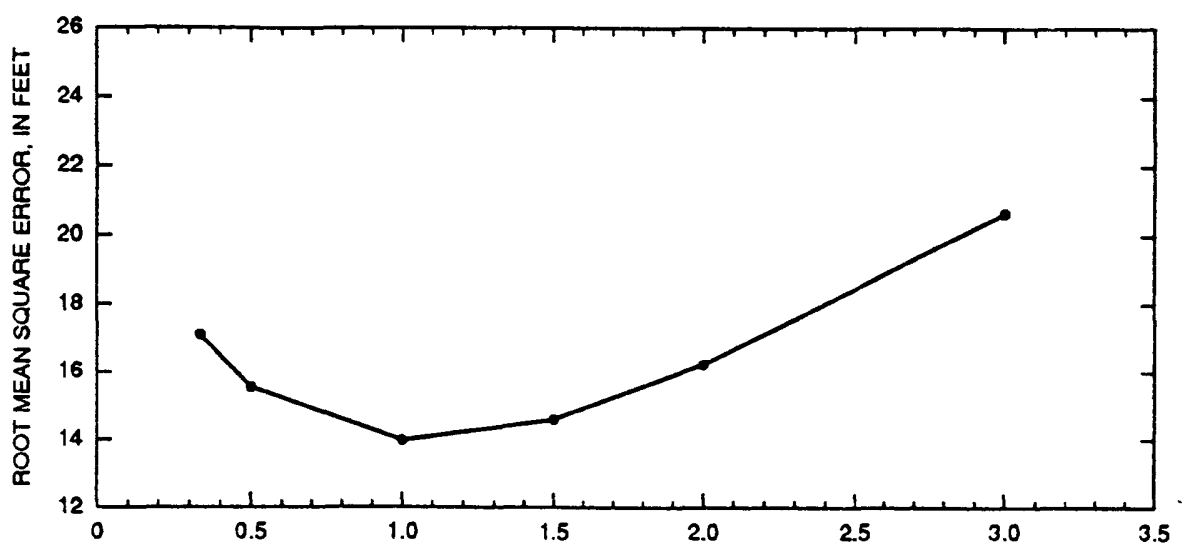

(A)

MULTIPLE OF CALIBRATED RECHARGE
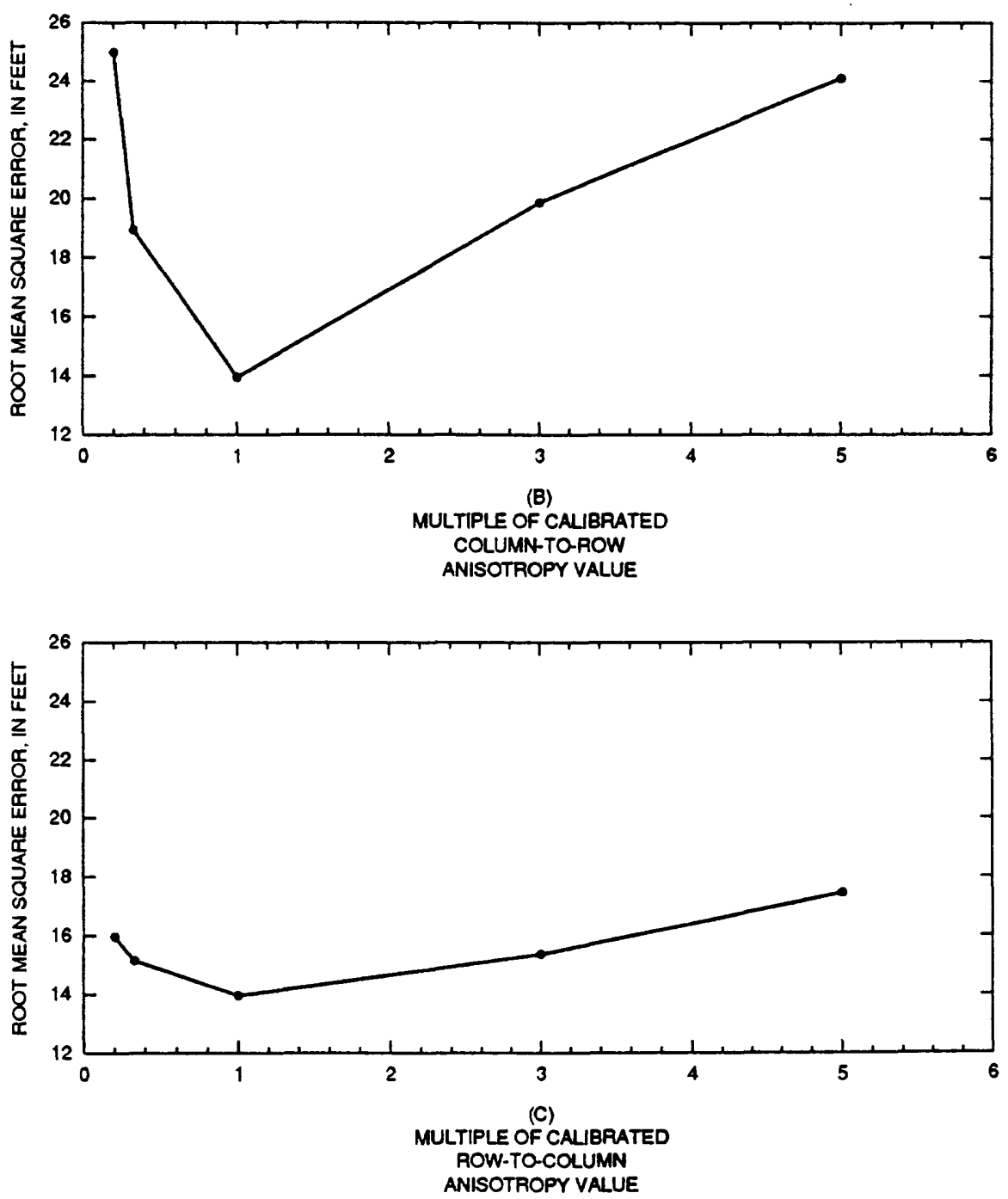

Figure 44. Sensitivity of ground-water-flow model of Arnold Air Force Base study area to adjustments in recharge, column-to-row anisotropy, and row-to-column anisotropy. 
2 followed by increases in hydraulic conductivity of layer 3, adjustments in recharge, and the addition of any anisotropy. The results also show that the values used in the calibrated model are reasonable approximations of actual conditions within the aquifers (table 8).

\section{Particle-Tracking Analysis}

A particle-tracking program, MODPATH (Pollock, 1989), was used to depict flow paths of ground water from three IRP sites: site 3, Coffee County Landfill; site 6, Camp Forrest watertreatment plant; and, site 8, leaching pit No. 1 (fig. 45). MODPATH uses the results from the model simulations to depict pathlines of groundwater flow and the position of water particles at specified times.

MODPATH is based on advective transport only and cannot be used to compute solute concentrations in ground water. Particle-tracking analyses were done using the calibrated model (average annual hydrologic conditions) for sites 3,6 , and, 8. Particles were tracked forward from the location of these sites to depict flow paths from the sites. The initial locations of the particles were in layers 1 and 2 because the shallow and Manchester aquifers are highly susceptible to contamination and support most of the ground-water flow. No particles were placed in layer 3 . In order to determine time-of-travel for the particles, porosities of 0.10 for layer $1,0.15$ for layer 2 , and 0.01 for layer 3 were used.

At the site 3 location, 124 particles were placed in 124 grid cells distributed equally in layers 1 and 2. The results indicate that the particles move to the northwest, out from the AAFB boundary, towards Cat Creek and Bates Spring Branch which both flow into the Duck River (fig. 46). The estimate of travel time for ground water leaving site 3 to reach these discharge areas is from 4 to 21 years depending on the flow path.

At the site 6 location, 92 particles were distributed equally in 4 grid cells in layers 1 and 2 . The results indicate that the particles follow a linear pattern of flow to Spring Creek on the south- western part of the base (fig. 47). The time-oftravel estimate of these particles ranges from 24 to 175 years depending on the flow path.

At the site 8 location, 28 particles were placed in 4 grid cells equally distributed in layers 1 and 2 . Most of the particles discharge to Brumalow Creek with a few discharging to Woods Reservoir (fig. 48). The estimated time-of-travel for the particles to reach these discharge areas ranges from 24 to 178 years depending on the flow path.

\section{SUMMARY AND CONCLUSIONS}

Three aquifers within the Highland Rim aquifer system, the shallow aquifer, the Manchester aquifer, and the Fort Payne aquifer, have been identified in the Arnold Air Force Base study area. Of these, the Manchester aquifer is the most important source of water for domestic use. This aquifer consists of water-bearing chert rubble and solution openings and fractures in the upper part of the bedrock. Both the shallow and Manchester aquifers are highly susceptible to contamination. Any ground-water contaminants migrating beyond the Arnold Air Force Base boundary are most likely transported within the shallow or Manchester aquifer.

Water-quality analyses show similar calcium bicarbonate type water in the shallow and Manchester aquifers. Water in the underlying Fort Payne aquifer is transitional towards a calcium bicarbonate sulfate type. Water from the deeper upper Central Basin aquifer system is a sodium sulfate chloride type and has high dissolved solids, chloride, and lithium concentrations.

Drilling and water-quality data indicate that the Chattanooga Shale is an effective confining unit, isolating the Highland Rim aquifer system from the upper Central Basin aquifer system. Little ground water flows through the Chattanooga Shale.

A ground-water divide, approximately coinciding with the Duck River-Elk River drainage divide, runs from southwest to northeast across Arnold Air Force Base. Laterally, ground-water flow directions are generally from the divide, northwest and 
Table 8. Ranges of variation of hydraulic characteristics for sensitivity analysis of ground-water-flow model of Arnold Air Force Base study area

[in/yr, inches per year; $t / d$, foot per day; $(t t / d) / f t$, foot per day per foot]

Recharge (in/yr)

Hydraulic conductivity

$(\mathrm{ft} / \mathrm{d})$

Vertical conductance between layers: $[(\mathrm{ft} / \mathrm{d}) / \mathrm{ft}]$

Conductance of rivers and drains $[(\mathrm{ft} / \mathrm{d}) / \mathrm{ft}]$

Horizontal anisotropy

Row to Column

Column to Row

$\begin{array}{rr}\begin{array}{r}\text { on the divide } \\ \text { around the divide }\end{array} & 10.0 \\ & 6.0 \\ \text { Layer } 1 & 73 \\ 2 & 64 \\ 3 & 1.7\end{array}$

1 and 2

2 and 3

0.00032 to

66

3.4

0.58

66

$1: 1$

$1: 1$
3.3

2.0

0.73

0.064

0.017

to 7,300

to 6,400

to 170

0.000034 to 3,400

0.000058 to 580

Multiple from

0.05 to 5

$1: 0.2$ to $1: 5$

0.2:1 to $5: 1$

southeast towards the tributary streams that drain the area. Recharge to the ground-water system is primarily from precipitation, and estimates of average annual recharge rates range from 4 to $11 \mathrm{in} / \mathrm{yr}$.

Digital computer modeling was used to simulate and provide a better understanding of the ground-water-flow system. Calibrated values of hydraulic conductivity for the shallow, Manchester, and Fort Payne aquifers were 73, 64, and $1.7 \mathrm{ft} / \mathrm{d}$, respectively. Calibrated recharge rate was $10 \mathrm{in} / \mathrm{yr}$ along the divide and $6 \mathrm{in} / \mathrm{yr}$ elsewhere. Simulation results indicate that most of the ground-water flow occurs in the shallow and Manchester aquifers.
The model was most sensitive to increases in hydraulic conductivity and any change in recharge rates.

Particle-tracking analysis from selected sites of known ground-water contamination indicate a potential for contaminant transport beyond the boundary of Arnold Air Force Base. Particle tracking from the Coffee County landfill indicates that ground water moves to the west and discharge to streams and springs along the Highland Rim escarpment. Particle tracking from the Camp Forrest water-treatment plant indicates that ground water flows southeast and discharges to Spring Creek. Particle tracking from Leaching Pit Number 1 indicates that ground water flows to the southeast and south and discharges to Brumalow Creek, its tributaries, and Woods Reservoir. 

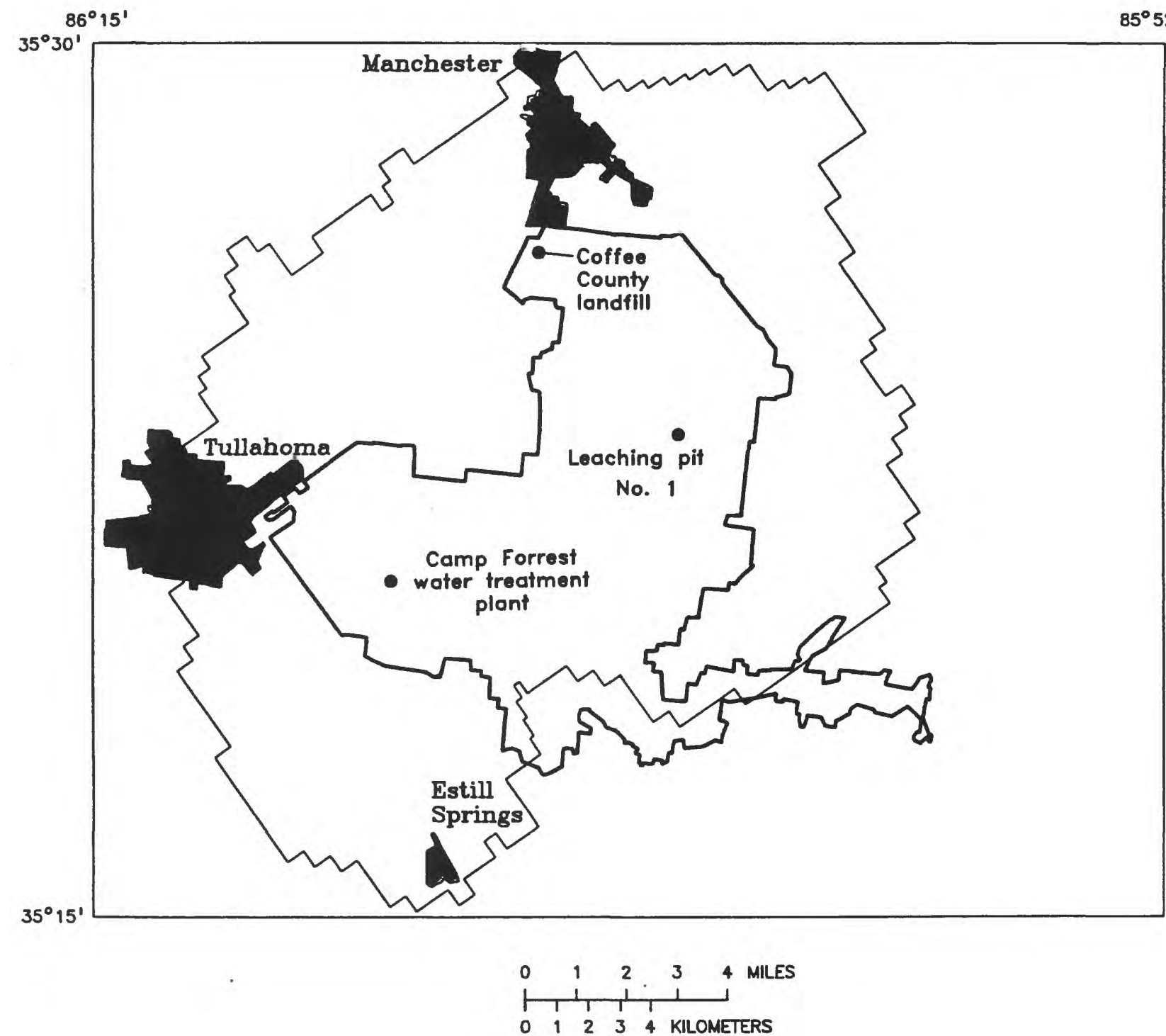

EXPLANATION

INCORPORATED TOWN

MODEL BOUNDARY

ARNOLD AIR FORCE

BASE BOUNDARY

Figure 45. Location of sites used for particle-tracking analysis at Arnold Air Force Base. 


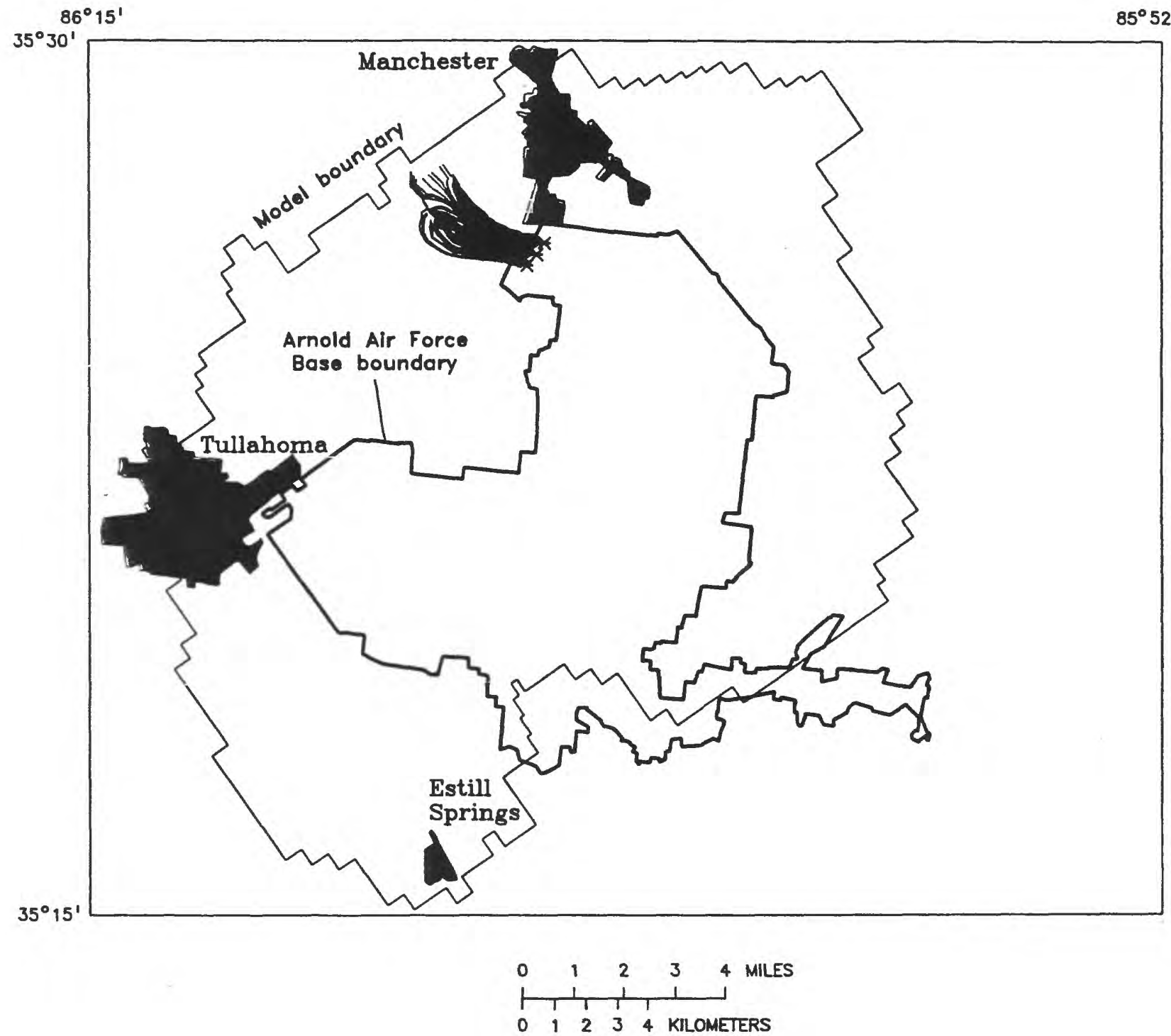

EXPLANATION

INCORPORATED TOWN

FLOW LINE

* STARTing point of

PARTICLE TRACKING

Figure 46. Forward particle tracking from Coffee County landfill (site 3) at Arnold Air Force Base.

Hydrogeology and Simulation of Ground-Water Flow at

Arnold Air Force Base, Coffee and Franklin Counties. Tennessee 


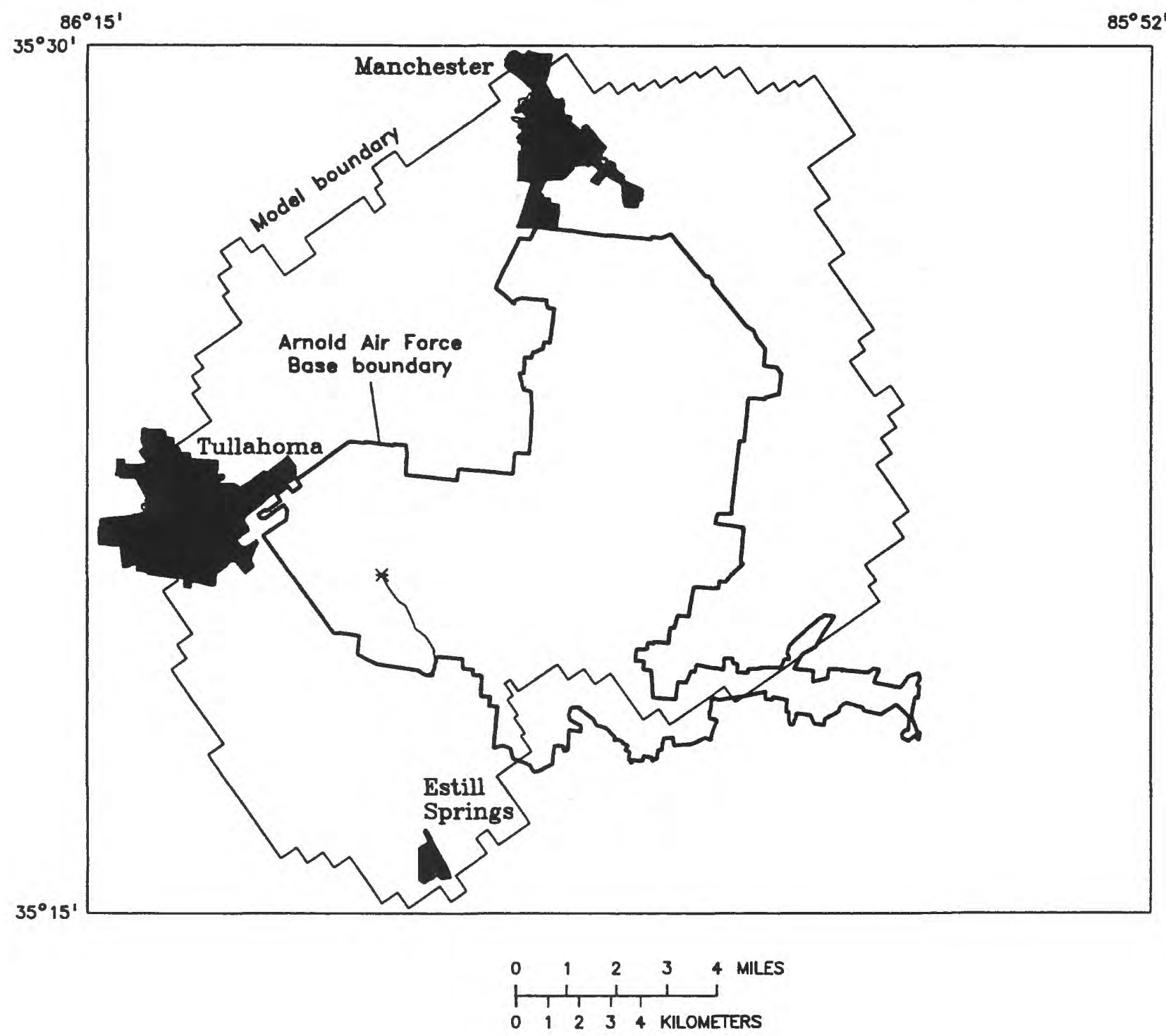

EXPLANATION

INCORPORATED TOWN

FLOW LINE

* Starting poINT of

PARTICLE TRACKING

Figure 47. Forward particle tracking from Camp Forrest water-treatment plant (site 6) at Arnold Air Force Base. 

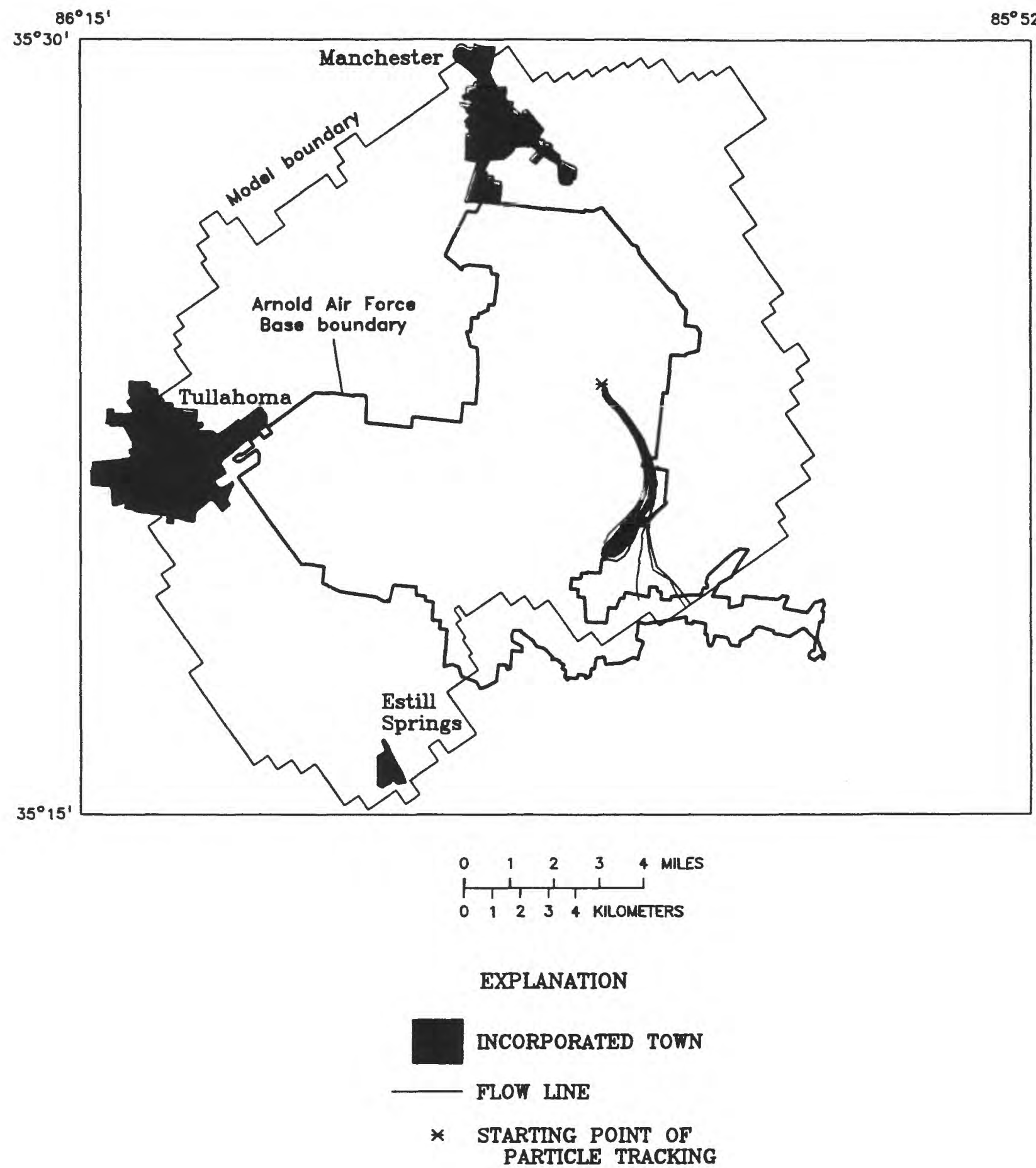

Figure 48. Forward particle tracking from leaching pit No. 1 (site 8 ) at Arnold Air Force Base.

66 Hydrogeology and Simulation of Ground-Water Flow at Arnold Air Force Base, Coffee and Franklin Counties, Tennessee 


\section{SELECTED REFERENCES}

Arnold Air Force Base, 1989, Basic support and logistics brochure: unnumbered document, January 1989, 43 p.

Ausich, W.I., and Meyer, D.L., 1990, Origin and composition of carbonate buildups and associated facies in the Fort Payne Formation (Lower Mississippian, south-central Kentucky): An integrated sedimentologic and paleoecologic analysis: Geological Society of America Bulletin, v. 102 , p. $129-146$.

Barker, J.F., Barbash, J.E., and Lalonte, M., 1988, Ground-water contamination at a landfill sited on fractured carbonate and shale: Journal of Contaminant Hydrology, v. 3, p. 1-25.

Battelle Columbus Division, 1988, Installation restoration program, Phase II-Confirmation/Quantification, Stage 1, Final report, Amold Engineering Development Center, Arnold Air Force Station, Tennessee: Columbus, Ohio, Contract no. F33615-85-D-4507, Delivery order no. 12, July 1988, 7 sections.

1989a, Installation restoration program, RI/FS, Stage 2, Quality assurance project plan, Amold Engineering Development Center, Amold Air Force Base, Tennessee: Golden, Colorado, Contract no. F33615-85-D-4507, Task order no. 18, 2 sections.

$1989 \mathrm{~b}$, Installation restoration program, RI/FS, Stage 2, Work plan, Amold Engineering Development Center, Arnold Air Force Base, Tennessee: Golden, Colorado, Contractno. F33615-85-D-4507, Delivery order no. 18, 7 sections.

Battelle Denver Operations, 1989, Installation restoration program, RI/FS, Stage 2, Informal technical information report -- Field and analytical data, Arnold Air Force Base, Tennessee: Golden, Colorado, Contract no. F33615-85-D-4507, Delivery order no. 26,267 p.

Benham Group, 1989a, Base comprehensive plan, 65 percent submittal, Arnold Air Force Base, Tennessee: Contract no. F40650-88-COO14, June 5, 1989, 16 plans.

1989b, Executive summary -- Plan overview, 65 percent submittal, Arnold Air Force Base, Tennessee: Contract no. F40650-88-COO14, 6 sections, 1 appendix.
Brahana, J.V., and Bradley, M.W., 1986a, Preliminary delineation and description of the regional aquifers of Tennessee - The Highland Rim aquifer system: U.S. Geological Survey Water-Resources Investigations Report 82-4054, 38 p.

1986b, Preliminary delineation and description of the regional aquifers of Tennessee - The Central Basin aquifer system: U.S. Geological Survey Water-Resources Investiga-tions Report 82-4002, $35 \mathrm{p}$.

Brahana, J.V., Thrailkill, John, Freeman, Tom, Ward, W.C., 1988, Carbonate rocks, in Back, William, Rosenshein, J.S., and Seaber, P.R., eds., Geology of North America: Boulder, Colorado, The Geological Society of America, v. 0-2, chap. 38, Hydrogeology, p. 333-352.

Burchett, C.R., 1977, Water resources of the upper Duck River basin, Central Tennessee: Tennessee Division of Water Resources, Water Resources Series no. 12,103 p.

Burchett, C.R., Brahana, J.V., and Hollyday, E.F., 1980 , The occurrence of ground water in relation to facies within the Fort Payne Formation in Tennessee: Geological Society of America Abstracts with Programs, Annual Meeting, 1980, Atlanta, Georgia, p. 395.

Burchett, C.R., and Hollyday, E.F., 1974, Tennessee's newest aquifer: Geological Society of America Abstracts with Programs, v. 6, no. 4, 338 p.

Chebotarev, I.I., 1955, Metamorphism of natural waters in the crust of weathering. Geochimica et Cosmochimica Acta, 8.

Chowns, T.M., and Elkins, J.E., 1974, The origin of quartz geodes and cauliflower cherts through the silicification of anhydrite nodules: Journal of Sedimentary Petrology, v. 44, no. 3, p. 885-903.

Conant, L.C., and Swanson, V.E., 1961, Chattanooga Shale and related rocks of central Tennessee and nearby areas: U.S. Geological Survey Professional Paper 357, $91 \mathrm{p}$.

Dames and Moore, 1975, Technical report, Groundwater investigation and foundation study Aerospace-Jet Propulsion Systems Test Facility (ASTF): unnumbered document, September 11, 1975, $40 \mathrm{p}$.

Daniel, J.F., 1976, Estimating groundwater evapotranspiration from streamflow records: Water Resources Research, v. 12, no. 3, p. 360-364. 
Engineering-Science, 1984, Installation restoration program, Phase I: Records search, Arnold Engineering Development Center (AEDC), Tennessee: Atlanta, Ga., Engineering Science, consulting engineer, unnumbered document, October 1984, 6 sections.

Harbaugh, A.W., 1990, A computer program for calculating subregional water budgets using results from the U.S. Geological Survey modular threedimensional finite-difference ground-water flow model, U.S. Geological Survey Open-File Report 90-392, 46 p.

Hart, T.A., 1985, Geologic map and mineral resources summary of the Capitol Hill quadrangle, Tennessee: Tennessee Division of Geology, MRS 86-SE, scale $1: 24,000$.

Haugh, C.J., Mahoney, E.N., and Robinson, J.A., 1992, Well-construction, water-level, geophysical, and water-quality data for ground-water monitoring wells for Arnold Air Force Base, Tennessee, U.S. Geological Survey Open-File Report 92-135, 88 p.

Hickman, R.C., and Lynch, V.J., 1967, Chattanooga Shale investigations: U.S. Bureau of Mines Report of Investigation 6932.

Hoos, A.B., 1990, Recharge rates and aquifer hydraulic characteristics for selected drainage basins in Middle and East Tennessee, U.S. Geological Survey Water-Resources Investigations Report 90-4015, 34 p.

Hunt, T.M., 1979, Petroleum chemistry and geology: San Francisco, Calif., W.H. Freeman and Co.

Lattman, L.H., and Parizek, R.R., 1964, Relationship between fracture traces and the occurrence of ground water in carbonate rocks in central Pennsylvania: Amsterdam, Journal of Hydrology, v. 2 , no. 23 , p. 73-91.

McDonald, M.G., and Harbaugh, A.W., 1988, A modular three-dimensional finite-difference ground-water flow model: Techniques of WaterResources Investigations of the United States Geological Survey, book 6, chap. A1, 576 p.

Miller, R.A., 1974, The geologic history of Ten-nessee, Tennessee Division of Geology, Bulletin 74, 58 p. 1987, Geologic map and mineral resources summary of the Hillsboro quadrangle, Tennessee: State of Tennessee, Division of Geology, MRS 93-NW, scale 1:24,000.

Moore, G.K., Burchett, C.R., and Bingham, R.H., 1969, Limestone hydrology in the upper Stones
River basin, central Tennessee: Tennessee Division Water Resources Research Series 1, 58 p.

Moore, J.L., 1977, Geologic map and mineral resources summary of the Alto quadrangle, Tennessee: State of Tennessee, Division of Geology, MRS 93-SW, scale 1:24,000.

Moran, M.S., 1977, The Fort Payne Formation and differential aquifer development along the eastern Highland Rim, central Tennessee: Nashville, Tennessee, Vanderbilt University, Master Science Thesis, 120 p.

Oak Ridge National Laboratory, 1989a, U.S. Air Force Installation restoration program, Phase IV, Remedial design for site 10, Amold Engineering Development Center, Tullahoma, Tennessee, Task 2.7 Baseline analytical report: Oak Ridge National Laboratory, Tennessee, Hazardous Waste Remedial Actions Program, August 1989, 6 sections, 5 appendices.

1989b, U.S. Air Force Installation Restoration Pro-gram, Draft risk assessment for site 10, Arnold Engineering Development Center, Arnold Air Force Base, Tennessee: Hazardous Waste Remedial Actions Program unnumbered document, second draft, December 1989, 103 p.

Pollock, D.W., 1989, Documentation of computer programs to compute and display pathlines using results from the U.S. Geological Survey modular three-dimensional finite-difference ground-water flow model: U.S. Geological Survey Open-File Report 89-381, 188 p.

Post, Buckley, Schuh and Jernigan, Inc., 1989a, Installation restoration program, Phase IV-A, Site 1, Remedial action plan, v. I, Amold Air Force Base, Tennessee: Nashville, Tenn., consulting engineer report, 6 sections, 3 appendices.

$1989 \mathrm{~b}$, Installation restoration program, Phase IV-A, Site 1, Remedial action plan, v. II, (Appendix D, Site investigation report) Arnold Air Force Base, Tennessee: Nashville, Tenn., consulting engineer report, 7 sections.

1989c, Installation restoration program, Phase IV-A, Site 1, Remedial action plan, v. III, (Support documentation) Arnold Air Force Base, Tennessee: Nashville, Tenn., consulting engineer report, 10 appendices.

1989 d, Installation restoration program, Phase IV-A, Site 1, Environmental assessment, Amold Air Force Base, Tennessee: Nashville, Tenn., consulting engineer report, 4 sections. 
1989e, Draft work management plan for groundwater extraction investigation for site 1 , Arnold Engineering Development Center: Nashville, Tenn., consulting engineer report, 6 sections.

1989f, Draft site safety and health plan for remedial action system design investigation for site 1, Arnold Engineering Development Center: Nashville, Tenn., consulting engineer report, 8 sections, 2 appendices.

$1989 \mathrm{~g}$, Draft quality management plan for remedial action system design investigation for site 1, Arnold Engineering Development Center: Nashville, Tenn., consulting engineer report, 3 sections, 5 appendices.

Rorobaugh, M.I., 1964, Estimating changes in bank storage and ground-water contribution to streamflow: International Association of Science and Hydrology Publication 63, p. 432-441.

Science Applications International Corporation, 1990, Installation restoration program, Remedial Investigation/Feasibility Study, Stage 2, Technical report draft, Arnold Air Force Base, Tennessee: Golden, Colo., Contract no. F33615-85D-4543, Task order no. 6,3 v., 5 sections, 11 appendices.

Siddiqui, S.H., and Parizek, R.R., 1971, Hydrogeologic factors influencing well yields in folded and faulted carbonate rocks in central Pennsylvania: Water Resources Research, v. 7, no. 5, p. 1295-1312.

Slaine, D.D., and Barker, J.F., 1990, The detection of naturally occurring BTX during a hydrogeologic investigation: Groundwater Monitoring Review, p. 89-94.

Smith, Ollie, Jr., 1962, Ground-water resources and municipal water supplies of the Highland Rim in Tennessee: Tennessee Division Water Resources, Water Resources Series no. 3, 237 p.

Theis, C.V., 1936, Ground water in south-central Tennessee: U.S. Geological Survey Water-Supply Paper 677, $182 \mathrm{p}$.
U.S. Army Corps of Engineers, Mobile District, 1988a, Final foundation report, FY-89 PDC ANZY870198 Large Rocket Test Facility (J-6), Arnold Engineering Development Center, Air Force Systems Command, Arnold Air Force Station, Tennessee: U.S. Army Corps of Engineers, 94 p., 19 plates. 1988b, Final foundation report, FY-89 PDC ANZY870198 Large Rocket Test Facility (J-6), Appendix A, Arnold Engineering Development Center, Air Force Systems Command, Arnold Air Force Station, Tennessee: U.S. Army Corps of Engineers, $309 \mathrm{p}$.

U.S. Environmental Protection Agency, 1986, RCRA ground-water monitoring technical enforcement guidance document: Cincinnati, Ohio, U.S. Environmental Protection Agency OSWER-9950.1, $208 \mathrm{p}$.

Wilson, C.W. Jr., 1970, Geologic map and mineral resources summary of the Ovoca quadrangle, Tennessee: Tennessee Division of Geology, MRS $86-\mathrm{NW}$, scale $1: 24,000$.

1973, Geologic map and mineral resources summary of the Tullahoma quadrangle, Tennessee: Tennessee Division of Geology, MRS 86-SW, scale 1:24,000.

1976, Geologic map and mineral resources summary of the Manchester quadrangle, Tennessee: Tennessee Division of Geology, MRS 86-NE, scale $1: 24,000$.

Wilson, C.W., Jr., and Born, K.E., 1943, Structure of Central Tennessee: Bulletin of the American Association of Petroleum Geologists, v. 27, 1044 p.

Woodward-Clyde Consultants, 1990, Ground water extraction investigation report, Hazardous waste site no. 1, Arnold Engineering Development Center, Arnold Air Force Base, Tullahoma, Tennessee: Consulting engineer report, September 28, 1990, 7 sections, 7 appendices.

Zurawski, Ann, 1978, Summary appraisals of the Nation's ground-water resources--Tennessee Region: U.S. Geological Survey Professional Paper 813-L, 35 p. 